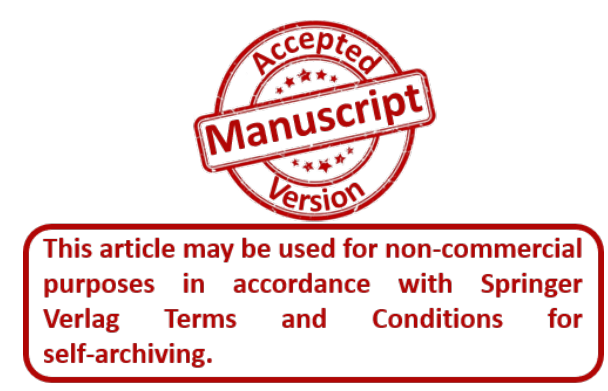

\title{
Catalytic Transformations of Alkynes via Ruthenium Vinylidene and Allenylidene Intermediates
}

\author{
Jesús A. Varela, Carlos González-Rodríguez, Carlos Saá
}

Departamento de Química Orgánica y Centro Singular de Investigación en Química Biológica y Materiales Moleculares (CIQUS), Universidad de Santiago de Compostela, 15782 Santiago de Compostela, Spain

carlos.saa@usc.es

1. Introduction 5

2. Nucleophilic Addition to Catalytic Ruthenium Vinylidenes 6

2.1. O- and S-Nucleophiles 6

2.2. N- and P-Nucleophiles $\quad 15$

2.3. C-Nucleophiles 21

2.4. B-Nucleophiles 26

3. Intramolecular Cyclizations $\quad 27$

4. Pericyclic Reactions 31

4.1. Electrocyclizations $\quad 31$

4.2. Cycloadditions 34

4.2.1. [2+2] Cycloadditions $\quad 34$

4.2.2. [4+2] Cycloadditions $\quad 36$

4.3. [1,5] Sigmatropic Rearrangements $\quad 37$

5. Vinylideneruthenium Catalysts in Metathesis 39

6. Ruthenium Allenylidenes in Catalysis 41

6.1. Nucleophilic Addition to Allenylidenes $\mathrm{C} \gamma \quad 42$

6.2. Nucleophilic Addition to Allenylidenes C $\alpha \quad 47$

6.3. Pericyclic Reactions with Ruthenium Allenylidenes 49

6.3.1. Cycloadditions $\quad 49$

6.3.2. Allenylidene-ene Reactions $\quad 50$

6.4. Allenylideneruthenium Catalysts in Metathesis $\quad 52$

7. Conclusion $\quad 55$

References 


\section{Abbreviations}

\begin{tabular}{|c|c|}
\hline Ac & acetyl \\
\hline acac & acetylacetonate \\
\hline AIBN & 2,2'-azobisisobutyronitrile \\
\hline anhyd & anhydrous \\
\hline $\mathrm{Ar}$ & aryl \\
\hline 9-BBN & 9-borabicyclo[3.3.1]nonane \\
\hline $\mathrm{Bn}$ & benzyl \\
\hline Bpy & 2,2'-bipyridyl \\
\hline Boc & tert-butoxycarbonyl \\
\hline $\mathrm{Bp}$ & boiling point \\
\hline $\mathrm{Bu}$ & butyl \\
\hline$s-\mathrm{Bu}$ & sec-butyl \\
\hline$t-\mathrm{Bu}$ & tert-butyl \\
\hline $\mathrm{Bz}$ & benzoyl \\
\hline CAN & ceric ammonium nitrate \\
\hline cat & catalyst \\
\hline $\mathrm{Cbz}$ & benzyloxycarbonyl \\
\hline CIP & Cahn-Ingold-Prelog \\
\hline cod & cyclooctadiene \\
\hline concd & concentrated \\
\hline $\cot$ & cyclooctatetraene \\
\hline Сp & cyclopentadienyl \\
\hline CSA & camphorsulfonic acid \\
\hline d & $\operatorname{day}(\mathrm{s})$ \\
\hline DABCO & 1,4-diazabicyclo[2.2.2]octane \\
\hline DBN & 1,5-diazabicyclo[4.3.0]non-5-ene \\
\hline DBU & 1,8-diazabicyclo[5.4.0]undec-7-ene \\
\hline DCC & $N, N$-dicyclohexylcarbodiimide \\
\hline DDQ & 2,3-dichloro-5,6-dicyano-1,4-benzoquinone \\
\hline de & diastereomeric excess (discouraged, see dr) \\
\hline DEAD & diethyl azodicarboxylate \\
\hline DET & diethyl tartrate \\
\hline DIBALH & diisobutylaluminum hydride \\
\hline DIPT & diisopropyl tartrate \\
\hline DMAP & 4-(dimethylamino)pyridine \\
\hline DMB & 3,4-dimethoxybenzyl \\
\hline DME & 1,2-dimethoxyethane \\
\hline DMF & dimethylformamide \\
\hline DMPU & 1,3-dimethyl-3,4,5,6-tetrahydro-2(1H)-pyrimidinone \\
\hline DMSO & dimethyl sulfoxide \\
\hline dppe & bis(diphenylphosphino)ethane \\
\hline dppm & bis(diphenylphosphino)methane \\
\hline $\mathrm{dr}$ & diastereomeric ratio \\
\hline
\end{tabular}




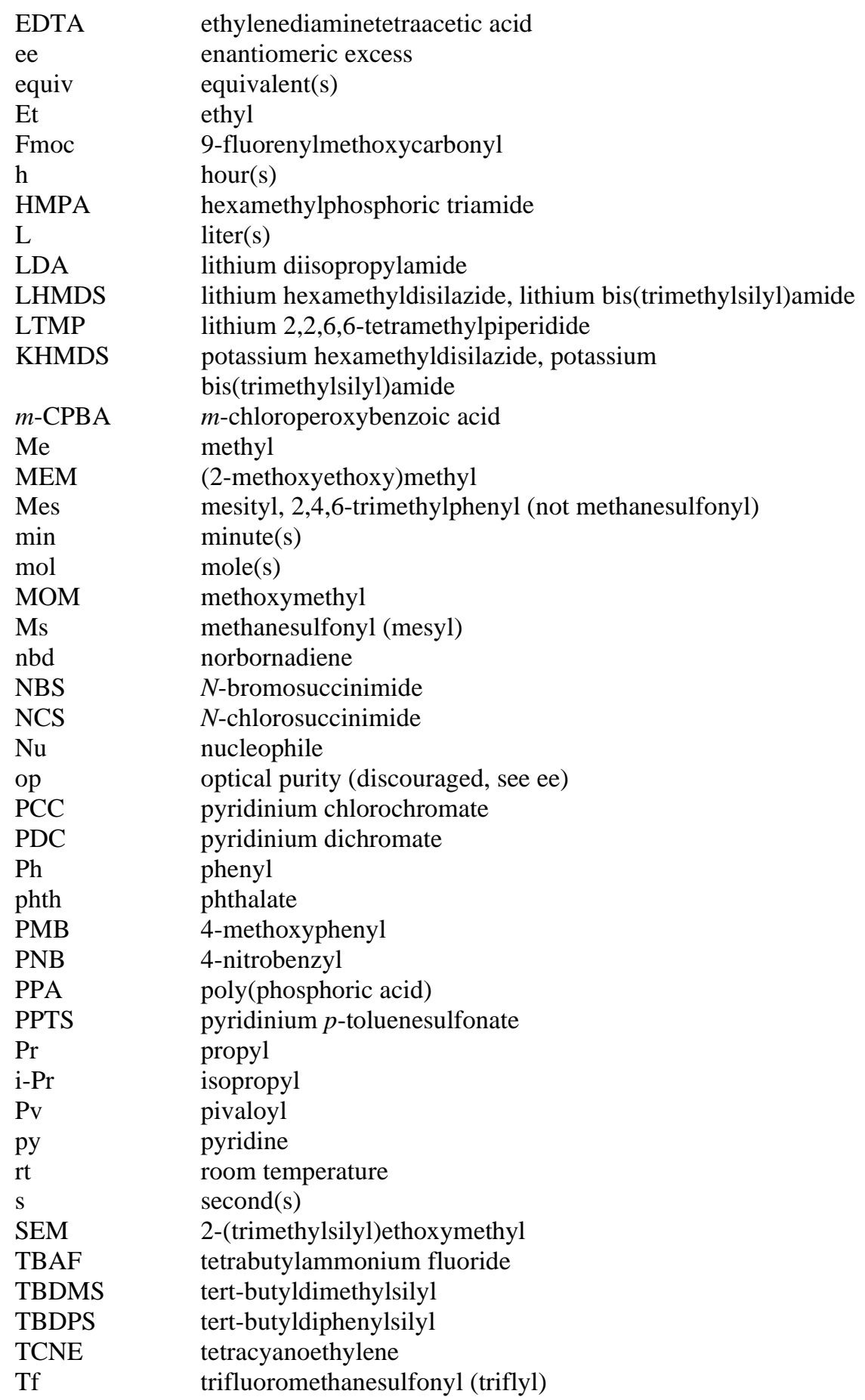




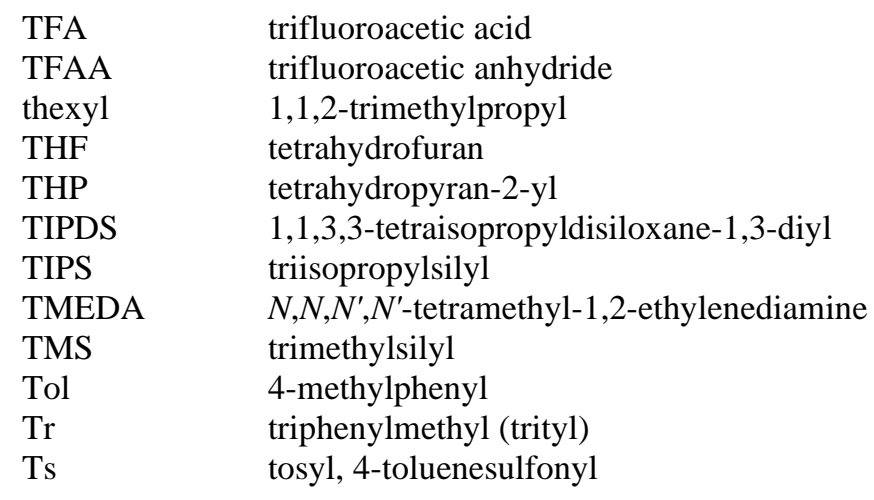

Abstract Vinylidenes are high-energy tautomers of terminal alkynes and they can be stabilized by coordination to transition metals. The resulting metal-vinylidene species have interesting chemical properties that make their reactivity different to that of the free and metal $\pi$-coordinated alkynes: the carbon $\alpha$ to the metal is electrophilic whereas the $\beta$ carbon is nucleophilic. Ruthenium is one of the most commonly used transition metals to stabilize vinylidenes and the resulting species can undergo a range of useful transformations. The most remarkable transformations are the regioselective anti-Markovnikov addition of different nucleophiles to catalytic ruthenium vinylidenes and the participation of the $\pi$ system of catalytic ruthenium vinylidenes in pericyclic reactions. Ruthenium vinylidenes have also been employed as precatalysts in ring closing metathesis (RCM) or ring opening metathesis polymerization (ROMP).

Allenylidenes could be considered as divalent radicals derived from allenes. In a similar way to vinylidenes, allenylidenes can be stabilized by coordination to transition metals and again ruthenium is one of the most widely used metals. Metal-allenylidene complexes can be easily obtained from terminal propargylic alcohols by dehydration of the initially formed metal-hydroxyvinylidenes, in which the reactivity of these metal complexes is based on the electrophilic nature of $\mathrm{C} \alpha$ and $\mathrm{C} \gamma$, while $\mathrm{C} \beta$ is nucleophilic. Catalytic processes based on nucleophilic additions and pericyclic reactions involving the $\pi$ system of ruthenium allenylidenes afford interesting new structures with high selectivity and atom economy.

Keywords Ruthenium vinylidenes, Ruthenium allenylidenes, Ruthenium catalysis 


\section{Introduction}

Free vinylidene is a high-energy tautomer of an alkyne that can be effectively stabilized by coordination to transition metals.[1] Since the first formation and stabilization of vinylidenes at a transition metal center reported in 1966,[2] a great deal of effort has been focused on both experimental and theoretical approaches to determine the mechanism for the transformation of terminal alkynes into the corresponding vinylidene complexes.[3] It is widely accepted that there are three general pathways through which this transformation can occur (Scheme 1) and each involves the initial formation of a complex that contains an alkyne in a $\eta^{2}$ binding mode. Two alternative pathways have been proposed for concerted migration of the hydrogen atom: (a) for $\mathrm{d}^{6}$ metal systems such as $\mathrm{Ru}(\mathrm{II})$ and $\mathrm{Mn}(\mathrm{I})$ complexes the migration proceeds by a 1,2-hydrogen shift (pathway 1, Scheme 1)[4,3]; (b) isomerization of the $d^{8}$ metal systems such as $\mathrm{Co}(\mathrm{I})$ and $\mathrm{Rh}(\mathrm{I})$ occurs by a 1,3-hydrogen shift via a hydride-alkynyl intermediate (pathway 2, Scheme 1).[5,3]. In the specific case where the central metal bears a hydride, a new route to vinylidenes has been identified and this involves the intermediacy of a metal alkenyl ligand, which can be obtained through insertion of an alkyne into a metal hydride bond (pathway 3, Scheme 1).[6,3,4b]

The conversion of internal alkynes to vinylidenes was considered an unusual process and it had only been reported for trialkylsilyl,[7] trimethylstannane,[8] alkylthiol[9] and iodo[10] substituted alkynes. Nevertheless, it has been recently reported the migration of acyl and aryl substituents in internal alkynes,[11] with the following order of the migratory efficiency: $\mathrm{CO}_{2} \mathrm{Et}>p-\mathrm{CO}_{2} \mathrm{EtC}_{6} \mathrm{H}_{4}>p$ $\mathrm{ClC}_{6} \mathrm{H}_{4}>\mathrm{Ph}>p-\mathrm{MeC}_{6} \mathrm{H}_{4} \mathrm{Me}>p-\mathrm{OMeC}_{6} \mathrm{H}_{4}$,[11] in which electron-withdrawing substituents on the aryl ring enhance the migratory aptitude.

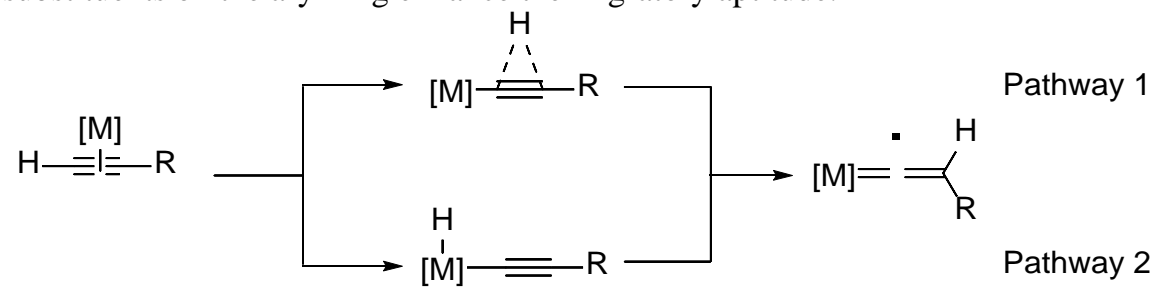

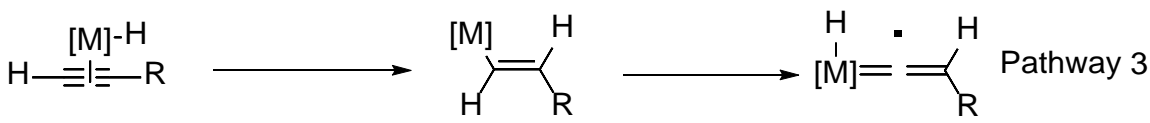

\section{Scheme 1}

The properties of vinylidene ligands are derived from the presence of an electrophilic coordinated carbon atom as well as the metal carbene character. The main processes in which metal-vinylidenes are involved that highlight their catalytic applications are: 
(a) Addition of nucleophiles to the electrophilic coordinated C $\alpha$.

(b) Alkyl, alkenyl or alkynyl migration from the metal center to the $\mathrm{C} \alpha$.

(c) Pericyclic reactions.

In this chapter the main applications of catalytic ruthenium vinylidenes that have been reported in the last decade are reviewed.[12]

\section{Nucleophilic Addition to Catalytic Ruthenium Vinylidenes}

Due to the electrophilic nature of the $\mathrm{C} \alpha$ in vinylidenes, their reactivity is dominated by the addition of nucleophiles to this position to afford Fischer-type carbenes (Scheme 2). Depending on the nature of the nucleophile and the subsequent evolution of the carbene a wide variety of compounds can be generated (aldehydes, dihydropyrans, furans, $\beta, \gamma$-unsaturated ketones, etc.).[12] The regioselectivity of this process led to the product resulting from addition of the nucleophile to the less substituted carbon of the alkyne (anti-Markovnikov addition), which is the opposite result to that observed when the alkyne is activated by a Lewis-acid (Markovnikov addition).

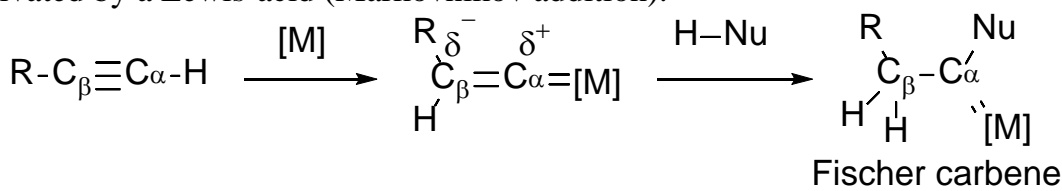

\section{Scheme 2}

\subsection{O- and S-Nucleophiles}

The use of catalytic vinylidenes was first reported by Dixneuf and Sasaki for the synthesis of alkenyl carbamates by anti-Markovnikov addition of an in situ generated carbamate to alkynes (Scheme 3).[13] Since then, several variations including catalyst modifications - have been attempted in an effort to improve selectivities and yields.[14] 


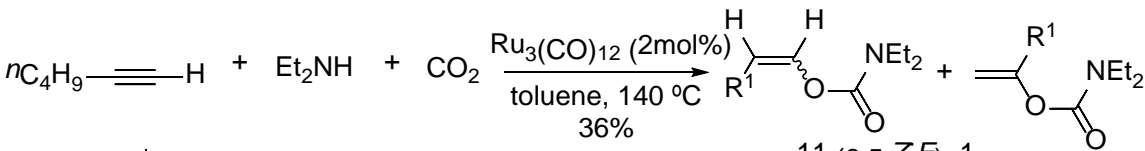

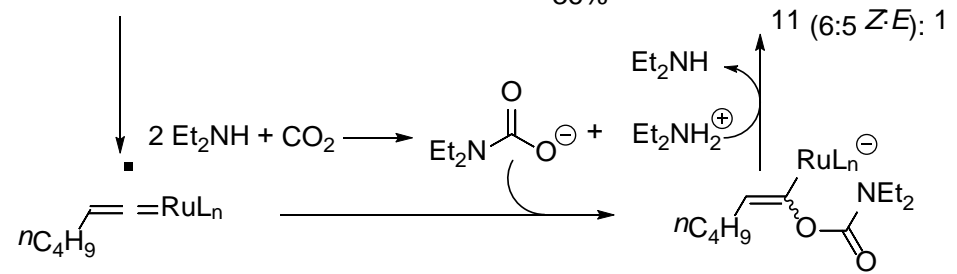

\section{Scheme 3}

Carboxylic acids are capable of adding to catalytic ruthenium vinylidenes to afford enol ester derivatives. The mechanism involves the formation of a ruthenium vinylidene species followed by nucleophilic attack of the benzoic acid to the electrophilic $\mathrm{C} \alpha$ of the vinylidene. The [Ru(2-methallyl $\left.)_{2} \mathrm{dppb}\right]$ complex has proven to be a superb catalyst for this transformation (Scheme 4).[15,16]

$$
\begin{aligned}
& \mathrm{R}^{1}=+\mathrm{PhCO}_{2} \mathrm{H} \underset{\mathrm{R}^{2}}{\stackrel{[\mathrm{Ru}(2-\text { methallyl) } 2 \mathrm{dppb}](2 \mathrm{~mol} \%)}{\text { toluene, } \Delta}} \mathrm{R}^{1} \mathrm{O}_{\mathrm{Ph}} \\
& \mathrm{R}^{1}=\mathrm{Ph}, n_{\mathrm{C}_{4} \mathrm{H}_{9}} \prod^{\xi_{2}} \\
& \text { 92-97\% }
\end{aligned}
$$

\section{Scheme 4}

Interestingly, modulation of the regioselectivity of the reaction from antiMarkovnikov (formation of the vinylidene) to Markovnikov (either by electrophilic activation of the alkynes or by oxidative addition of the acid to the ruthenium complex and subsequent migratory insertion and reductive elimination) was observed on using [( $p$-cymene $\left.) \mathrm{RuCl}_{2}\right]_{2}$ as the ruthenium catalyst and different phosphine ligands and bases (Table 1).[12d,g],[17]

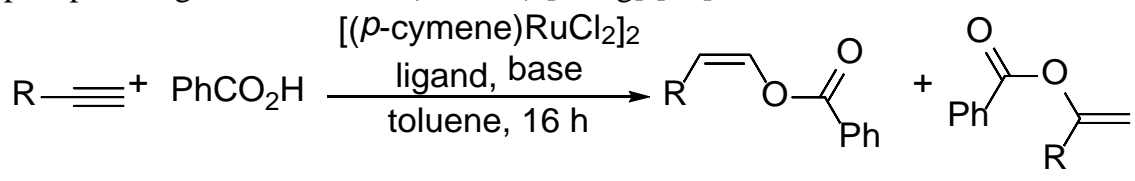

I

II

\begin{tabular}{|c|c|c|c|c|c|c|}
\hline $\mathrm{R}$ & $\begin{array}{c}\text { Cat. } \\
(\mathrm{mol} \%)\end{array}$ & Ligand (mol\%) & Base (mol\%) & $\begin{array}{c}\mathrm{T} \\
\left({ }^{\circ} \mathrm{C}\right)\end{array}$ & $\begin{array}{c}\text { Yield } \\
(\mathrm{mol} \%)\end{array}$ & I/II \\
\hline$n$-Bu & 1 & $\mathrm{P}\left(4-\mathrm{Cl}-\mathrm{C}_{6} \mathrm{H}_{4}\right)_{3}(3)$ & $\mathrm{DMAP}(4)$ & 60 & 89 & $50: 1$ \\
\hline$n-\mathrm{Bu}$ & 0.4 & $\mathrm{P}(\text { furyl })_{3}(0.8)$ & $\mathrm{Na}_{2} \mathrm{CO}_{3}(1.6)$ & 50 & 93 & $1: 30$ \\
\hline $\mathrm{Ph}$ & 1 & $\mathrm{P}\left(4-\mathrm{Cl}-\mathrm{C}_{6} \mathrm{H}_{4}\right)_{3}(3)$ & $\mathrm{DMAP}(4)$ & 60 & 99 & $50: 1$ \\
\hline $\mathrm{Ph}$ & 0.4 & $\mathrm{P}(\text { furyl })_{3}(0.8)$ & $\mathrm{Na}_{2} \mathrm{CO}_{3}(1.6)$ & 70 & 88 & $1: 1.5$ \\
\hline$t-\mathrm{Bu}$ & 1 & $\mathrm{P}\left(4-\mathrm{Cl}-\mathrm{C}_{6} \mathrm{H}_{4}\right)_{3}(3)$ & $\mathrm{DMAP}(4)$ & 80 & 68 & $50: 1$ \\
\hline$t-\mathrm{Bu}$ & 0.4 & $\mathrm{P}(\text { furyl })_{3}(0.8)$ & $\mathrm{Na}_{2} \mathrm{CO}_{3}(1.6)$ & 50 & 88 & $1: 10$ \\
\hline
\end{tabular}

Table 1 
Intramolecular anti-Markovnikov addition of carboxylic acids to alkynes was also achieved using ruthenium catalysts. $\alpha, \omega$-Alkynoic acids afford the corresponding cycloalkene lactones by intramolecular addition of the carboxylic acid to the corresponding catalytic vinylidene species obtained by treatment of the alkyne with the complex $\left[\mathrm{TpRu}[\mathrm{C}(\mathrm{Ph})=\mathrm{C}(\mathrm{Ph}) \mathrm{C} \equiv \mathrm{CPh}] \mathrm{PMe}(i-\mathrm{Pr})_{2}\right][18]$ or $\left[\mathrm{RuCl}_{\mathrm{x}}(p-\right.$ cymene)(triazol-5-ylidene)] (Scheme 5).[19]

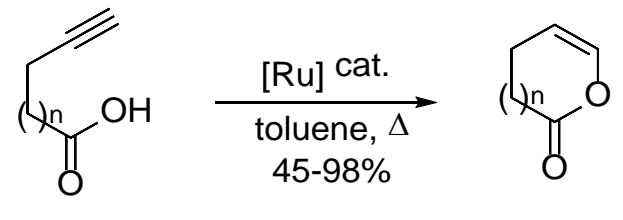

\section{Scheme 5}

$\mathrm{n}=1,2,3,7$

The enol esters obtained in this transformation can be further modified bearing in mind that they are protected aldehydes. Treatment of propargyl alcohols with benzoic acid in the presence of complex (dppe)Ru(2-methallyl) ${ }_{2}$ as catalyst affords the enol esters derived from the anti-Markovnikov addition of the acid to the alkyne (Scheme 6). Subsequent acid treatment gives rise to the conjugated enal, which is an isomer of the starting propargylic alcohol.[20]

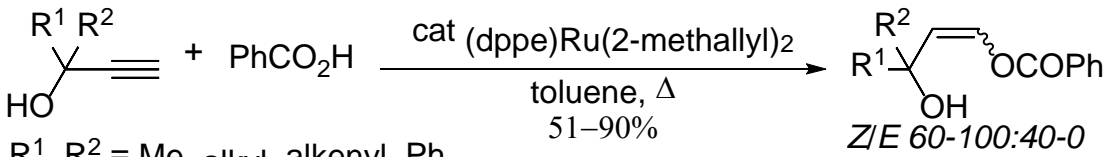

$$
\begin{aligned}
& \mathrm{R}^{1}, \mathrm{R}^{2}=\mathrm{Me} \text {, alkyl, alkenyl, } \mathrm{Ph}
\end{aligned}
$$
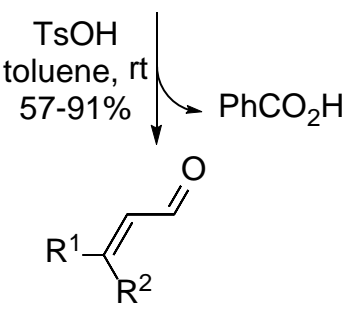

\section{Scheme 6}

The use of water as the nucleophile in the presence of a catalytic ruthenium vinylidene directly affords the aldehyde derived from the anti-Markovnikov hydration of a terminal alkyne. The first example of this reaction was reported by the group of Wakatsuki, who used $\left[\mathrm{RuCl}_{2}\left(\mathrm{C}_{6} \mathrm{H}_{6}\right)\right]_{2}$ or $\mathrm{RuCl}_{2}\left(\mathrm{C}_{6} \mathrm{H}_{6}\right)$ (phosphine) with additional specific phosphine ligands $\mathrm{PPh}_{2}\left(\mathrm{C}_{6} \mathrm{~F}_{5}\right)$ or $\mathrm{P}\left(3-\mathrm{C}_{6} \mathrm{H}_{4} \mathrm{SO}_{3} \mathrm{Na}\right)_{3}$.[21] The same research group reported that cyclopentadienylruthenium complexes of type A (Scheme 7) bearing bidentate phosphine ligands show much higher activity and complete selectivity to the anti-Markovnikov hydration product.[22,4b] Grotjahn and co-workers reported that other ruthenium catalysts obtained by changing the phosphine ligand for imidazolylphosphanes (type B, Scheme 7),[23] showed even better selectivities under milder conditions, i.e., room temperature and with lower catalytic loadings. On the other hand, Breit and co-workers 
showed that ruthenium catalysts bearing bidentate ligands, generated by the selfassembly of monodentate ligands through complementary hydrogen bonding of aminopyridine/isoquinoline systems, also lead to highly regioselective antiMarkovnikov hydration of terminal alkynes (type C, Scheme 7).[24]
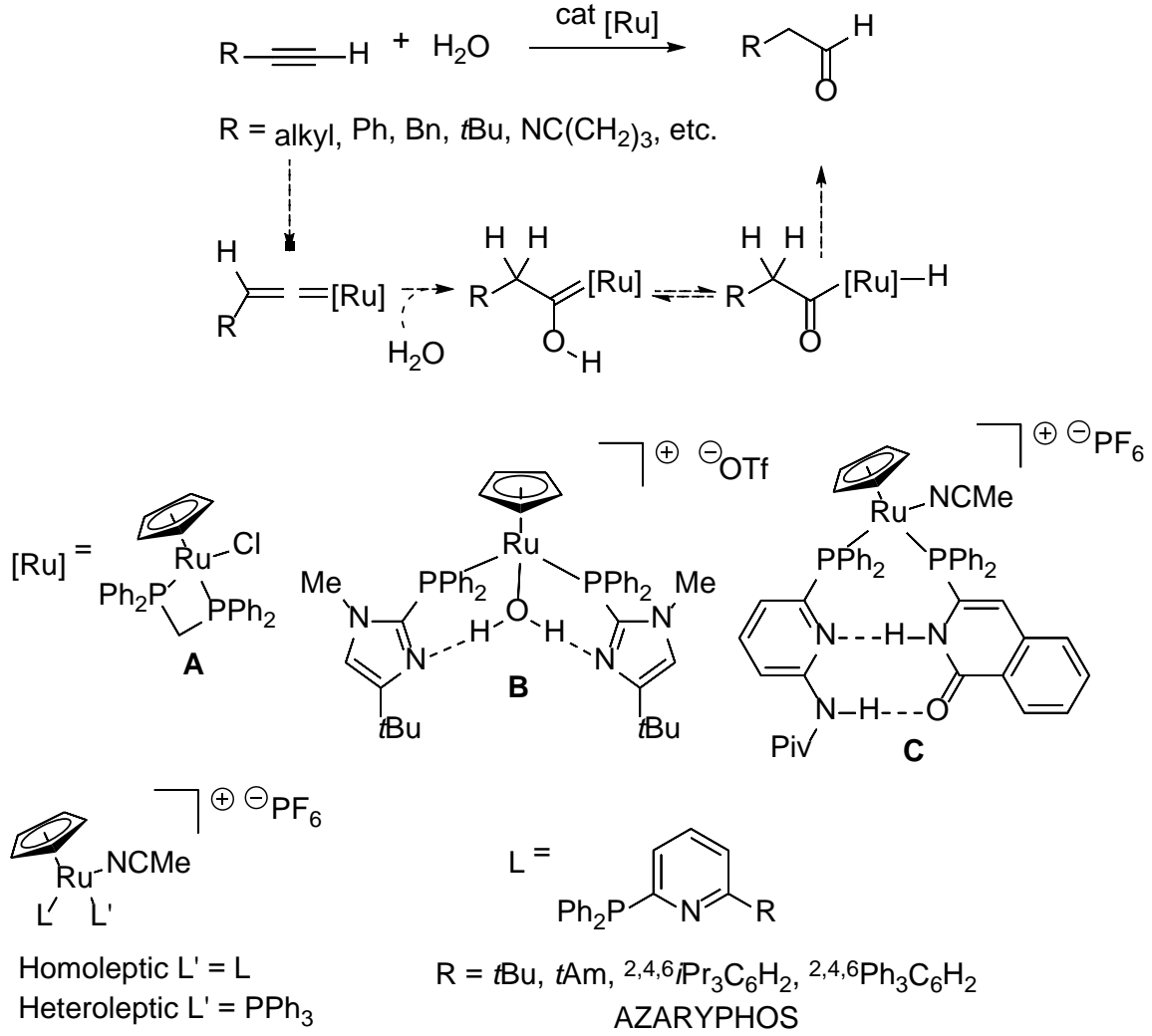

\section{Scheme 7}

Another family of phosphane ligands that contain a phosphine unit and sterically shielded nitrogen lone pairs in the ligand periphery are the so-called AZARYPHOS (aza-aryl-phosphane, L) ligands. The incorporation of these ligands into homoleptic ruthenium complexes $\left[\mathrm{RuCp}(\mathrm{L})_{2}(\mathrm{MeCN})\right]\left[\mathrm{PF}_{6}\right]$, either preformed [25] or generated in situ,[26] provides catalysts for the antiMarkovnikov hydration of terminal alkynes with the highest known activities.[27] Recently, heteroleptic ruthenium complexes $\left[\mathrm{RuCp}(\mathrm{L})\left(\mathrm{L}^{\prime}\right)(\mathrm{MeCN})\right]\left[\mathrm{PF}_{6}\right]$, in which $\mathrm{L}$ is AZARYPHOS and L' is a suitable non-functionalized placeholder phosphane ligand such as $\mathrm{PPh}_{3}$, have shown high catalytic activity. This result implies that only one bifunctional ligand is involved in the postulated ambifunctional reaction mechanism (Scheme 7).[28]

$N$-Protected $\beta$-amino aldehydes have been prepared from imines through a sequence that involves a Zn-mediated direct alkynylation followed by a Ru- 
catalyzed anti-Markovnikov alkyne hydration using a homoleptic ruthenium complex with AZARYPHOS ligands (Scheme 8).[29]

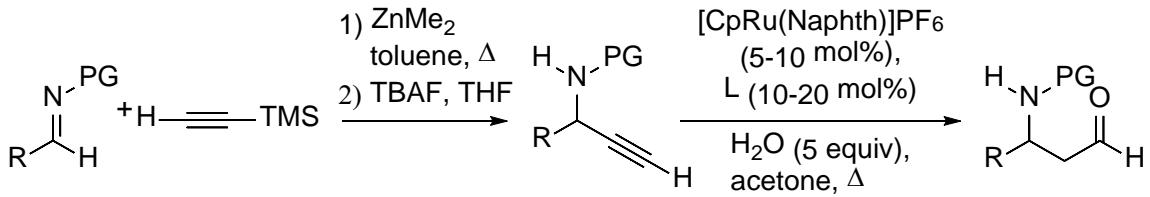

\section{Scheme 8}

Intermolecular addition of alcohols to catalytic ruthenium vinylidenes is far more difficult than the addition of water except when allylic alcohols are employed (Scheme 9).[30] In this case, the reaction of an allylic alcohol with a terminal alkyne catalyzed by $\mathrm{CpRuCl}\left(\mathrm{PPh}_{3}\right)_{2}$ afforded a $\beta, \gamma$-unsaturated ketone. The initial ruthenium oxacarbene obtained by addition of the alcohol to the ruthenium vinylidene evolves through a Claisen rearrangement to a $\pi$-allyl ruthenium species. Reductive elimination then gives rise to the final unsaturated ketone.

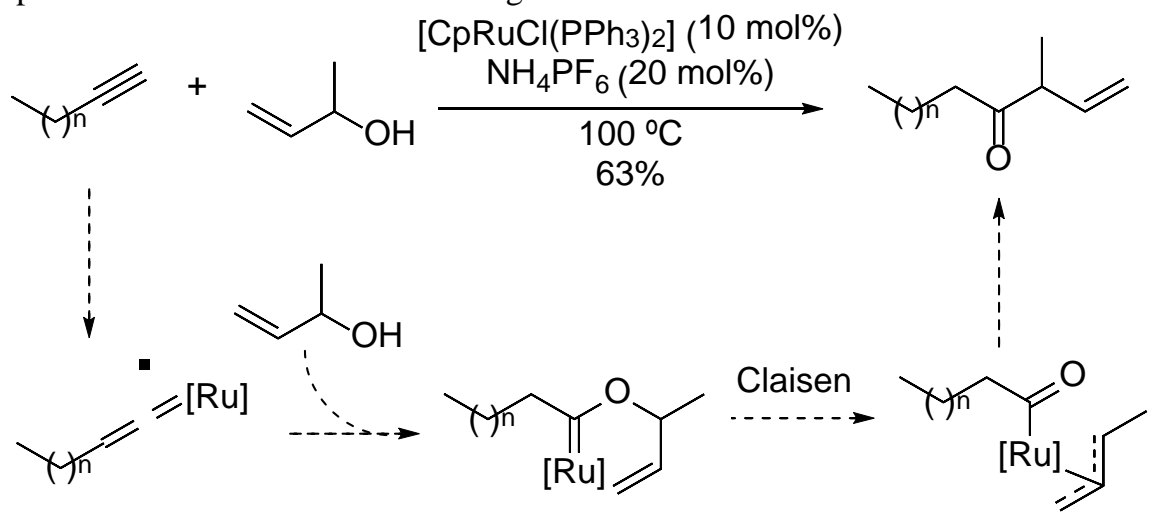

\section{Scheme 9}

Intramolecular addition of alcohols to vinylidenes to afford oxygen-containing heterocycles has been used more widely than the intermolecular version of this reaction.[31] Trost and co-workers described the cyclization of homo- and bishomopropargyl alcohols in the presence of catalytic ruthenium vinylidenes. Cyclization of homopropargyl alcohols in the presence of catalytic amounts of $\mathrm{CpRuCl}(\mathrm{cod})$ afforded the corresponding $\gamma$-butyrolactones by a sequence that involved intramolecular addition of the hydroxy group to the ruthenium vinylidene followed by oxidation of the initially formed hemiacetal group (Scheme 10).[32]

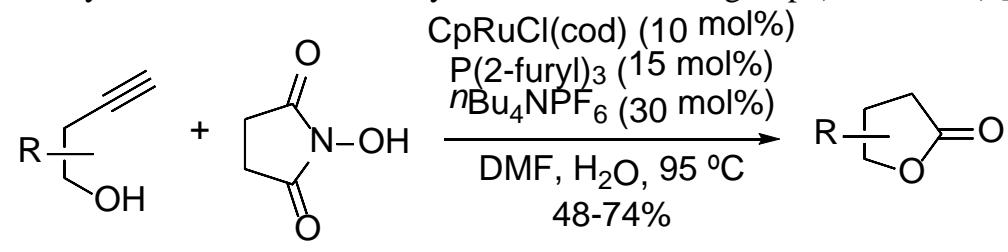

\section{Scheme 10}


On the other hand, cyclization of bis-homopropargyl alcohols with $\mathrm{CpRuCl}\left(\mathrm{PAr}_{3}\right)_{2}$ can be modulated depending on the electronic properties of the ligand.[33] The use of electron-donating ligands such as tris(4-methoxyphenyl)phosphine gave rise to $\delta$-valerolactone (addition of the hydroxy group to the Ru-vinylidene followed by oxidation), while the use of the electron-withdrawing ligand tris(4fluorophenyl)phosphine led to cycloisomerization to give dihydropyrans (addition of the hydroxy group to the Ru-vinylidene followed by $\beta$-hydride elimination) (Scheme 11).

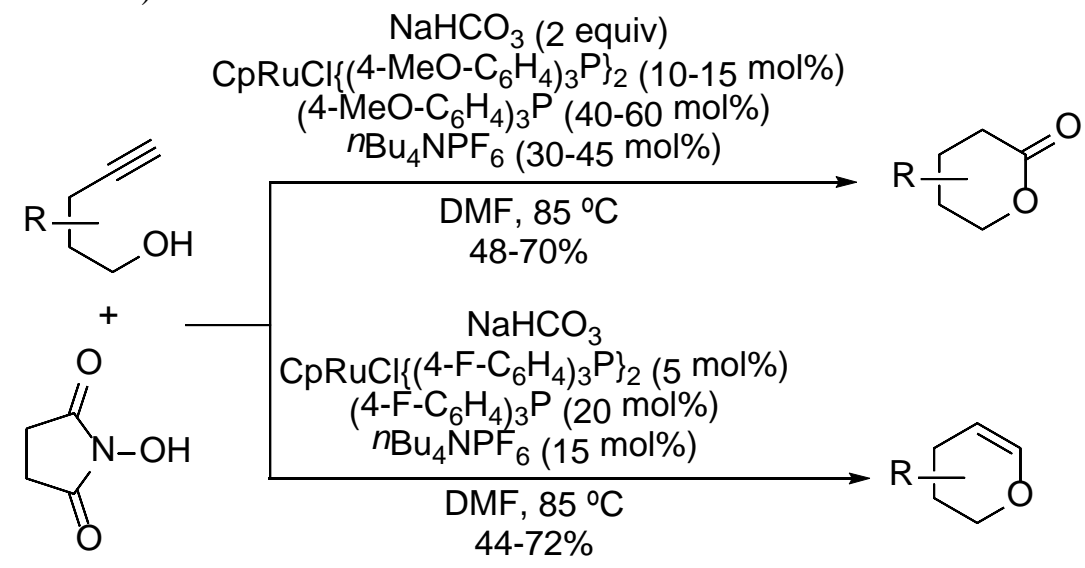

Scheme 11

These cycloisomerization conditions proved to be chemoselective for the Ocyclizations over the N-cyclizations. Dihydropyrans were the products obtained when aminoalcohols bearing an alkyne group were exposed to the Ru-catalyzed cycloisomerization conditions [i.e., $\mathrm{CpRuCl}\left(\mathrm{PPh}_{3}\right)_{2}, \mathrm{NaHCO}_{3}, \mathrm{~N}$ -

hydroxysuccinimide and $\mathrm{Bu}_{4} \mathrm{NPF}_{6}$ in $\mathrm{DMF}$ at $80^{\circ} \mathrm{C}$ for $8 \mathrm{~h}$ ] (Scheme 12).[34]
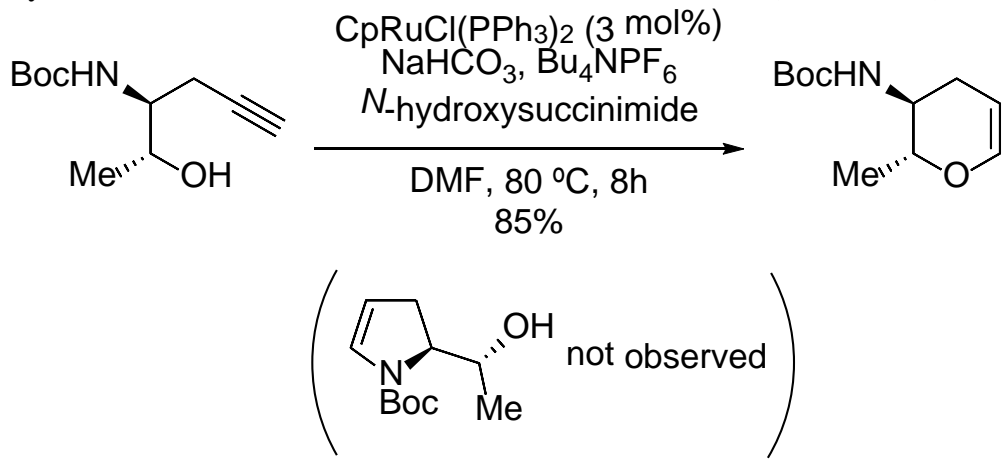

\section{Scheme 12}

The ruthenium complex $\left[\mathrm{Ru}\left(\mathrm{N}_{3} \mathrm{P}\right)(\mathrm{OAc})\right]\left[\mathrm{BPh}_{4}\right]$, in which $\mathrm{N}_{3} \mathrm{P}$ is the N,P mixed tetradentate ligand $N, N$-bis[(pyridin-2-yl)methyl]-[2-

(diphenylphosphino)phenyl]methanamine, was found to be catalytically active for the endo cycloisomerization of aliphatic alkynols to five-, six- and sevenmembered endo-cyclic enol ethers in good to excellent yield (Scheme 13).[35] 


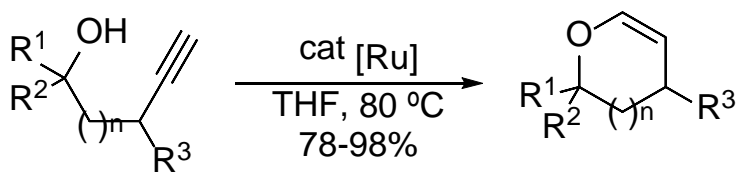

$\mathrm{n}=0,1,2$

\section{Scheme 13}

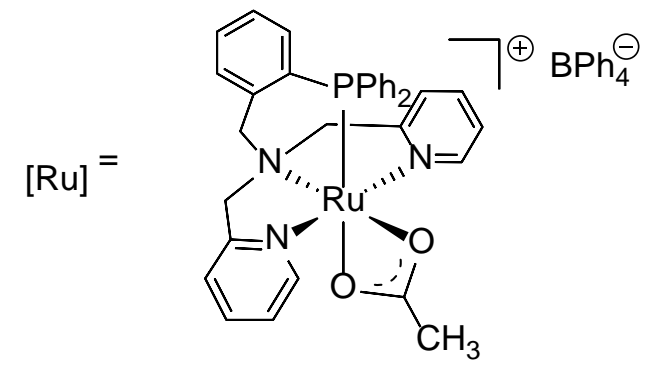

On the other hand, cycloisomerization of aromatic homo- and bishomopropargylic alcohols to benzofurans and isochromenes can be performed using catalytic $\mathrm{CpRuCl}\left(\mathrm{PPh}_{3}\right)_{2}$ in the presence of an amine as base (Scheme 14).[36] In a similar manner, benzofurans were also available from homopropargylic aromatic alcohols on using the bifunctional ruthenium catalyst $\left[\mathrm{RuL}_{2} \mathrm{Cp}\left(\mathrm{CH}_{3} \mathrm{CN}\right)\right]\left[\mathrm{PF}_{6}\right]$ (L = AZARYPHOS, see Scheme 7).[37]

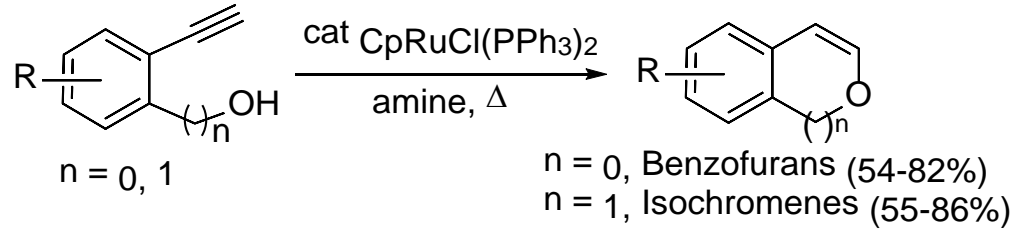

\section{Scheme 14}

The proposed mechanism begins with the dissociation of the chloride to afford the starting Ru precatalyst, which upon coordination with the corresponding alkyne would give rise to the key vinylidene intermediate A (Scheme 15). Nucleophilic attack by the pendant alcohol to the vinylidene with concurrent removal of a proton by the amine would provide alkenyl ruthenium species $\mathbf{B}$, which after protonolysis by the ammonium salt formed could provide the final benzofuran or isochromene with regeneration of the active catalyst (Scheme 15). 


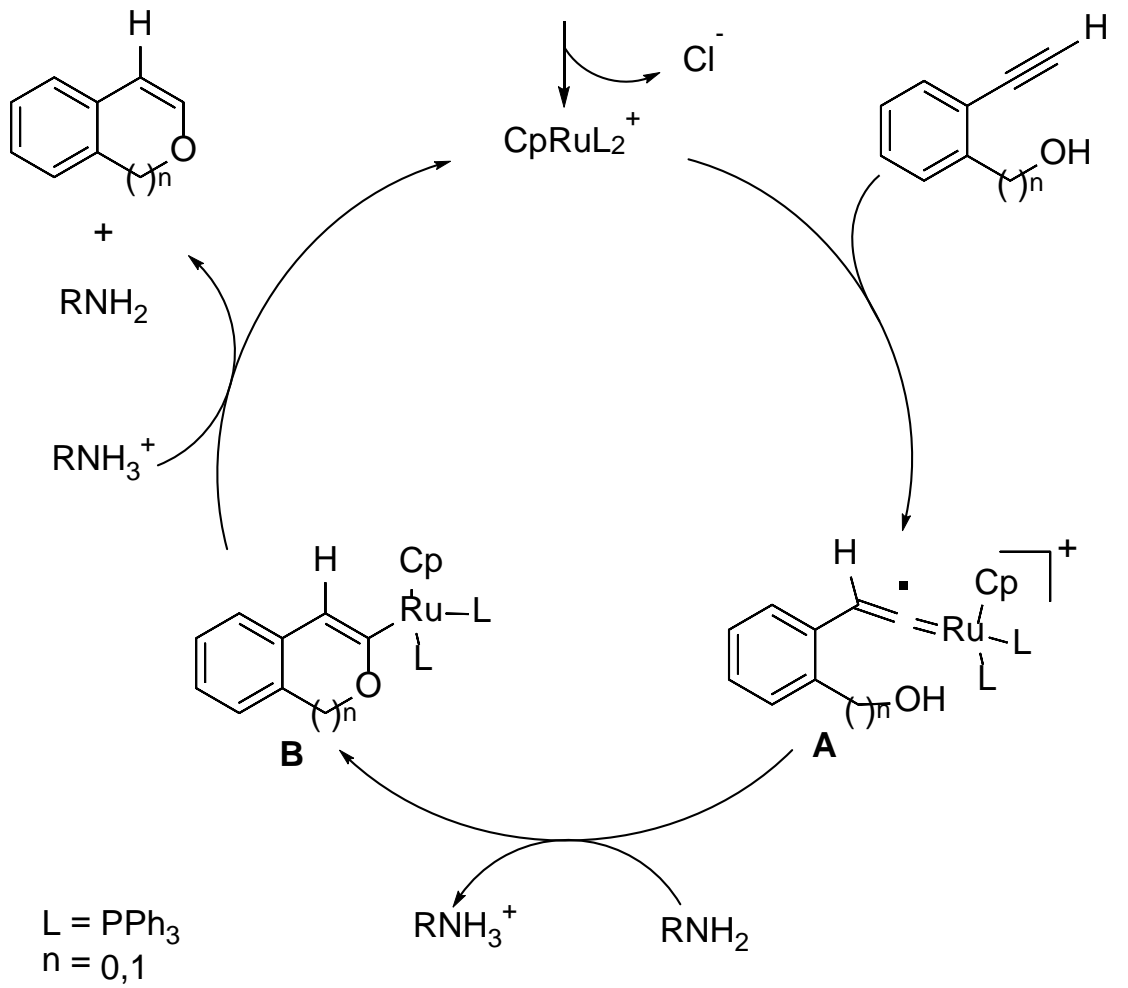

Scheme 15

Seven-membered oxygen heterocycles, 3-benzoxepines, were accessible by a similar methodology involving the use of tungsten vinylidene complexes,[38] but catalytic osmium vinylidenes proved to be more efficient than tungsten, ruthenium and rhodium vinylidenes for the regioselective 7-endo heterocyclization of aromatic alkynols into benzoxepines (Scheme 16).[39] The better efficiency could be explained as being due to the more reducing character of osmium compared to ruthenium (Os more easily oxidized), which could result into cleaner osmiumvinylidene formation (see pathway 2, Scheme 1) as compared to the formation of ruthemium-vinylidene via pathways 1 and 2 (Scheme 1), with possible more side reactions.<smiles>C#Cc1ccc(C)cc1CC(C)O</smiles>

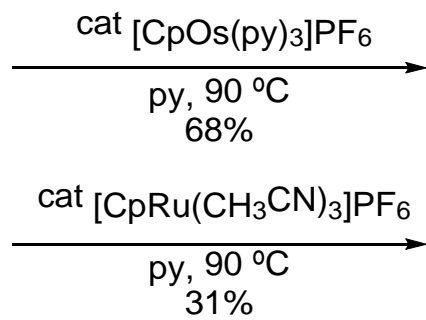<smiles>Cc1ccc2c(c1)CC(C)OC=C2</smiles> 


\section{Scheme 16}

The oxygen atom from epoxides can also act as a nucleophile in the cycloisomerization of epoxyalkynes to furans catalyzed by $\mathrm{TpRuCl}$ $\left(\mathrm{PPh}_{3}\right)\left(\mathrm{CH}_{3} \mathrm{CN}\right)_{2}$ in the presence of $\mathrm{Et}_{3} \mathrm{~N}$.[40] The initial ruthenium vinylidene species $\mathbf{A}$ would evolve to the ruthenium furylidene $\mathbf{B}$ by nucleophilic attack of the epoxide oxygen, which in the presence of base would afford ruthenium furyl anion C. Protonolysis would give rise to the final product and recovery of the catalytic ruthenium species (Scheme 17).

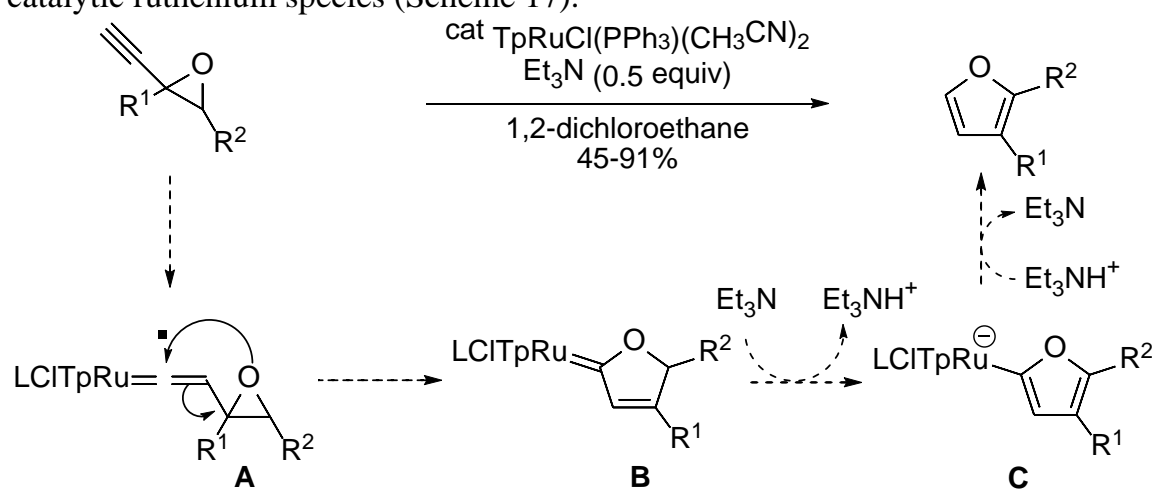

\section{Scheme 17}

The reaction of (o-ethynyl)phenyl epoxides in the presence of $\left[\mathrm{TpRu}\left(\mathrm{PPh}_{3}\right)(\mathrm{MeCN})_{2}\right] \mathrm{PF}_{6}$ gave different products depending on the epoxide substituents. 1',2'-Disubstituted epoxides gave 2-naphthol derivatives, whereas 1',2',2'-trisubstituted epoxides produced 1-alkylidene-2-indanones in good yields. A possible mechanism for this process involves ketene-alkene intermediates $\mathbf{A}$ (Scheme 18), which are generated by an oxygen migration from epoxide to the terminal alkyne initiated by nucleophilic attack of the epoxide to a ruthenium vinylidene. Finally, a 6-endo-dig cyclization would afford 2-naphthols and 5endo-dig cyclization would give rise to 1-alkylidene-2-indanones (Scheme 18).[41] The use of iodoalkynes such as 1-(2'-iodoethynylphenyl)-2-alkyloxiranes in DMF (Scheme 18, X = I) gave rise to 1-iodo-2-naphthols derived from the formation of the corresponding iodovinylidenes. Conversely, the use of benzene as solvent preferentially gave rise to 2-iodobenzo[ $d]$ oxepines due to the electrophilic activation of the alkyne by the ruthenium catalyst via a $\pi$-iodoalkyne species as intermediate.[42] 


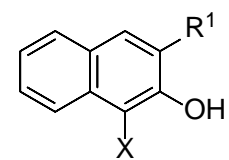

$$
\begin{aligned}
\mathrm{X}=\mathrm{H}, \mathrm{R}^{1=}= & n_{\mathrm{C}_{5} \mathrm{H}_{11}(81 \%)} \\
& i \operatorname{Pr}(72 \%) \\
& \operatorname{Ph}(95 \%)
\end{aligned}
$$

$$
X=I, \quad R^{1}=n_{C_{5}} H_{11}(87 \%)
$$

$$
\begin{gathered}
\text { 6-endo-dig } \\
\mathrm{R}^{2}=\mathrm{H}
\end{gathered}
$$

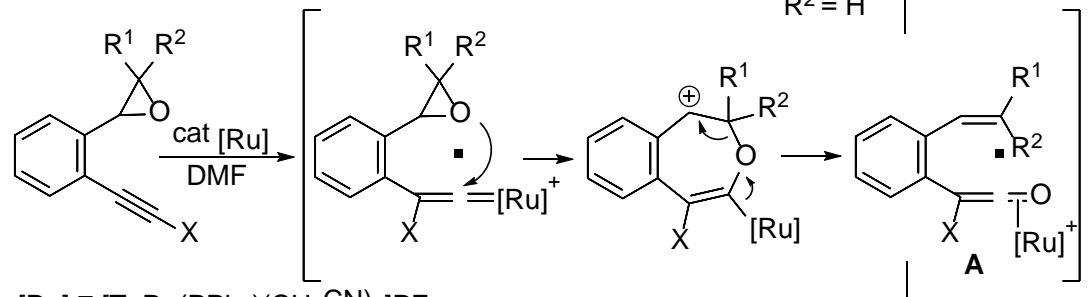

$[\mathrm{Ru}]=\left[\mathrm{TpRu}\left(\mathrm{PPh}_{3}\right)\left(\mathrm{CH}_{3} \mathrm{CN}\right)_{2}\right] \mathrm{PF}_{6}$

$$
\begin{array}{c|l}
\text { cat }[\mathrm{Ru}] & \mathrm{X}=\mathrm{I} \\
\text { benzene } & \mathrm{R}^{2}=\mathrm{H}
\end{array}
$$

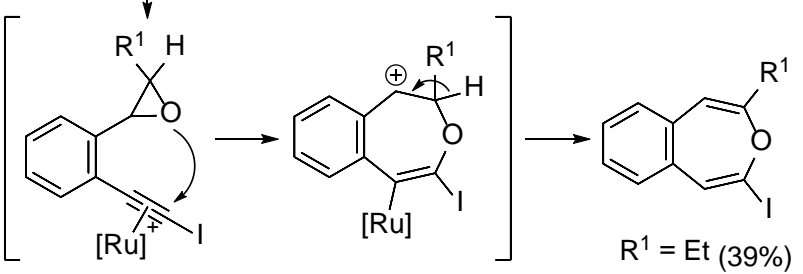

5-endo-dig $\mathrm{R}^{2} 7 \mathrm{H}$<smiles>[R]C([R])=C1C(=O)C([Y])c2ccccc21</smiles>

$X=H, R^{1}, R^{2}=M e(89 \%)$

\section{Scheme 18}

In contrast to oxygen, sulfur has been far less widely used as a nucleophile for addition to ruthenium vinylidenes. The formation of vinyl thioethers from the addition of thiols to alkynes catalyzed by binuclear ruthenium complexes $\mathrm{Cp} * \mathrm{Ru}(\mu-\mathrm{SR})_{2} \mathrm{RuCp}^{*}(\mathrm{R}=\mathrm{Et}, i-\mathrm{Pr}, t-\mathrm{Bu})$ and related complex $\mathrm{Cp} * \mathrm{Ru}\left(\mu^{1}-\mathrm{C}_{6} \mathrm{~F}_{5}\right)(\mu-$ $\mathrm{S})\left(\mu-\mathrm{SC}_{6} \mathrm{~F}_{5}\right) \mathrm{RuCp} *$ has been described.[43]

\section{2. $N$ - and P-Nucleophiles}

Nitrogenated nucleophiles can also add to $\mathrm{C} \alpha$ of ruthenium vinylidenes. Although the addition of simple primary or secondary amines to metal vinylidene intermediates in a catalytic reaction has not been reported to date, probably due to catalyst deactivation by the amine, the TpRuCl$\left(\mathrm{PPh}_{3}\right)_{2}$-catalyzed addition of $\mathrm{N}, \mathrm{N}$ dialkylhydrazines to alkynes to give nitriles has been reported.[44] In recent years 
Goossen and co-workers have described a range of customized protocols for the anti-Markovnikov addition of various $\mathrm{N}$-nucleophilic amides, thioamides and imides to terminal alkynes to afford enamides, thioenamides and enimides in a chemo-, regio- and stereoselective manner (Scheme 19). 


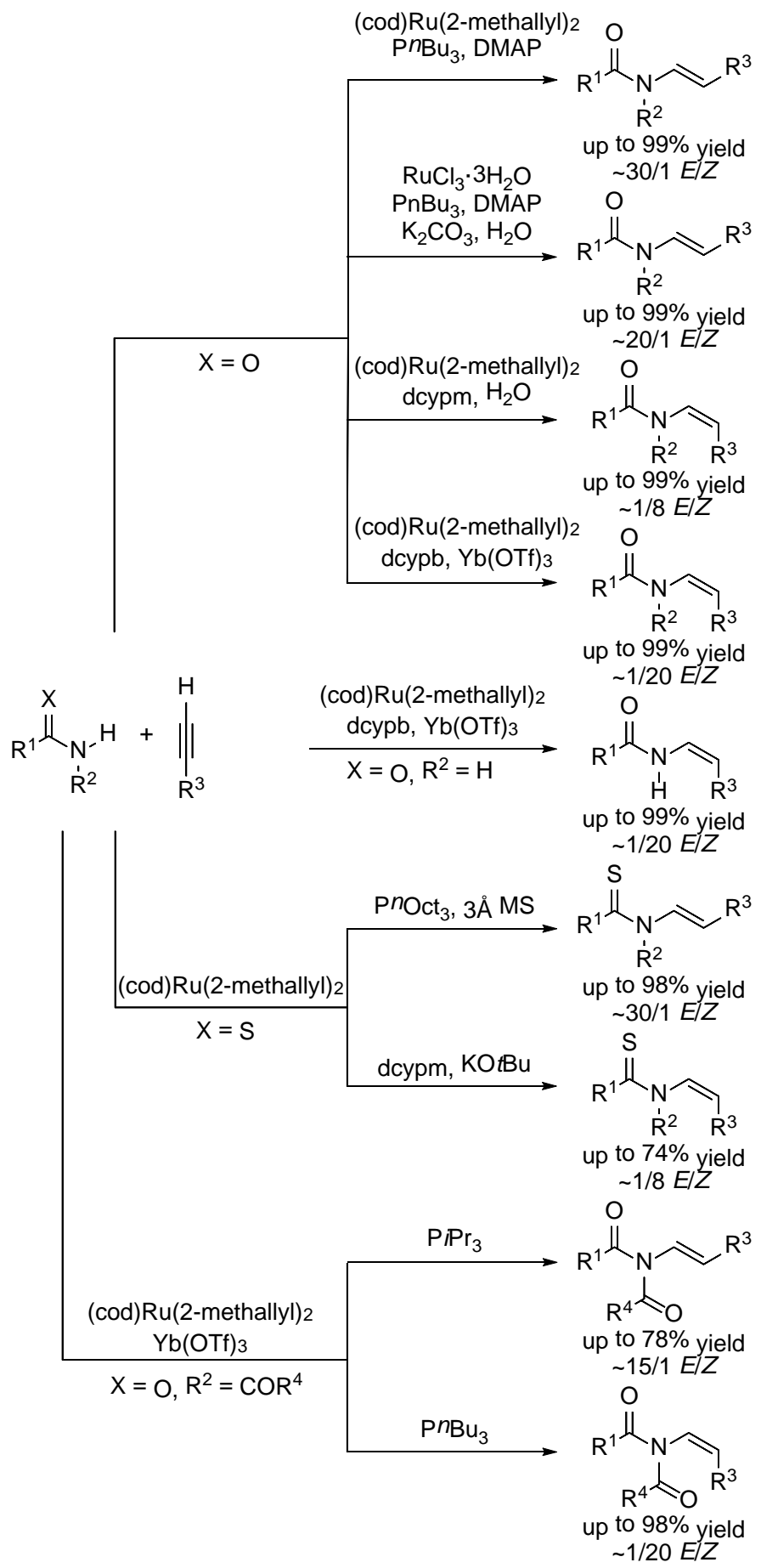

to $98 \%$ yield $-1 / 20$ ElZ 


\section{Scheme 19}

Tertiary (E)-enamides can be synthesized by the reaction of secondary amides with terminal alkynes in the presence of a catalyst system generated in situ from bis(2-methallyl)(cycloocta-1,5-diene)ruthenium(II) [(cod)Ru(2-methallyl) 2 ], tri- $n$ butylphosphine and 4-dimethylaminopyridine (Scheme 19, eq 1),[45] or by using a mixture of $\left(\mathrm{RuCl}_{3} \cdot 3 \mathrm{H}_{2} \mathrm{O}\right), \mathrm{P}(n-\mathrm{Bu})_{3}, \mathrm{DMAP}, \mathrm{K}_{2} \mathrm{CO}_{3}$ and water (Scheme 19, eq 2).[46] The stereoselectivity can be reversed in favor of the corresponding ( $Z$ )enamides by employing [(cod)Ru(2-methallyl $)_{2}$ ], bis(dicyclohexylphosphino)methane (dcypm) and water instead of $\mathrm{P}(n-\mathrm{Bu})_{3}$ and DMAP (Scheme 19, eq 3),[45] or the Lewis acid ytterbium(III) triflate in combination with [(cod)Ru(2-methallyl $\left.)_{2}\right] \quad$ and 1,4bis(dicyclohexylphosphino)butane dcypb (Scheme 19, eq 4).[47] The latter conditions also proved to be efficient for the synthesis of secondary $(E)$-enamides from primary amides and terminal alkynes (Scheme 19, eq 5).[48] The previously described catalytic conditions for the addition of amides to alkynes were also modified to allow the stereoselective addition of thioamides (Scheme 19, eq 6 and 7) [49] and imides to alkynes (Scheme 19, eq 8 and 9).[50]

Mechanistic studies on the Ru-catalyzed hydroamidation of terminal alkynes support the involvement of ruthenium hydride and ruthenium vinylidene species as the key intermediates.[51] The proposed pathway starts with the initial oxidative addition of the amide $\mathrm{N}-\mathrm{H}$ bond to the ruthenium complex to afford ruthenium hydride I followed by 1,2-insertion of a $\pi$-coordinated alkyne to vinylruthenium species II. Rearrangement to the vinylidene species III followed by nucleophilic attack of the amide and subsequent reductive elimination would give rise to the product (Scheme 20). 


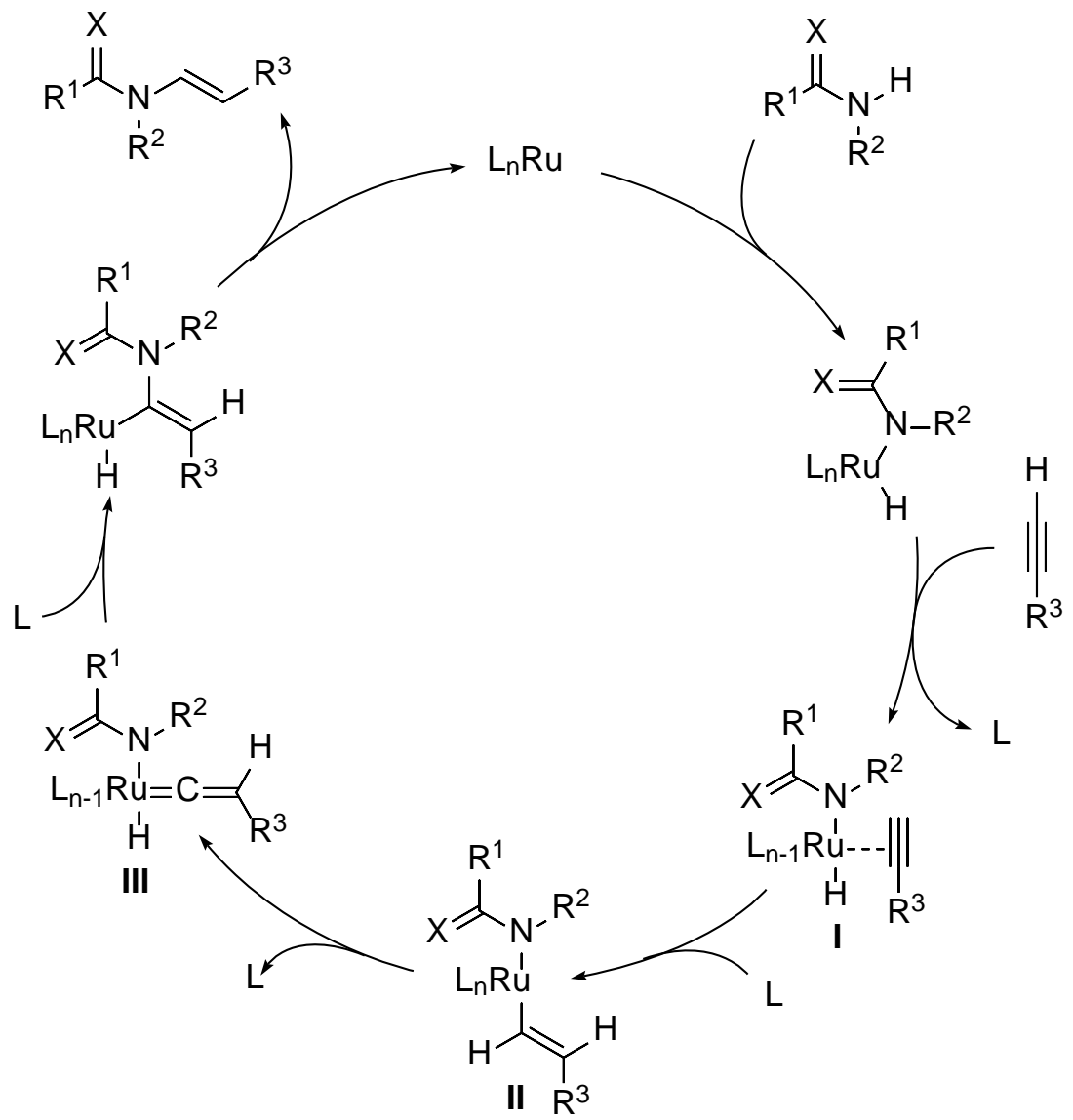

\section{Scheme 20}

This methodology can be used in an intramolecular fashion to synthesize different nitrogen heterocycles. Ruthenium-catalyzed cycloisomerizations of aromatic homo- and bis-homopropargylic amines/amides to indoles, dihydroisoquinolines and dihydroquinolines have been developed.

Grotjahn and co-workers used the same ruthenium catalyst as for antiMarkovnikov hydration of terminal alkynes, $\left[\mathrm{CpRuL}_{2}\left(\mathrm{CH}_{3} \mathrm{CN}\right)\right]\left[\mathrm{PF}_{6}\right](\mathrm{L}=$ AZARYPHOS, see Scheme 7),[25] to synthesize indoles from homopropargylic amines/amides in good yields.[37] The use of doubly ethynylated substrates in the presence of water gave rise to the product derived from cyclization to the indole plus anti-Markovnikov hydration of the second terminal alkyne (Scheme 21). 


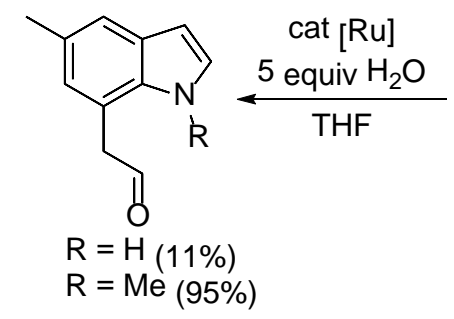<smiles>[R]Nc1c(C#C)cc(C)cc1C#C</smiles><smiles>[R]n1ccc2cc(C)cc(C#C)c21</smiles>

$\left.[\mathrm{Ru}]=\mathrm{CpRuL}_{2}\left(\mathrm{CH}_{3} \mathrm{CN}\right)\right]\left[\mathrm{PF}_{6}\right]$<smiles>CC(C)(C)c1cccc(P)n1</smiles>

\section{Scheme 21}

On using $\mathrm{CpRuCl}\left(\mathrm{PPh}_{3}\right)_{2}$ as catalyst in pyridine as solvent it was not only possible to synthesize indoles from aromatic homopropargylic amides but also 1,2dihydroisoquinolines and 1,4-dihydroquinoline from bis-homopropargylic amides (Scheme 22).[52] Surprisingly, cyclization of the latter amides under other typical conditions used for vinylidene formation, $\left[\mathrm{RuCl}_{2} \text { ( } p \text {-cymene) }\right]_{2} / \mathrm{PBu}_{3}$,[51] gave the 2-methylindole, which indicates that cyclization did not proceed through a ruthenium vinylidene.[52]

$$
\begin{aligned}
& \text { (Z) })^{n}{ }_{\mathrm{NHR}}^{\mathrm{CpRuCl}\left(\mathrm{PPh}_{3}\right) 2(10 \mathrm{~mol} \%)} \\
& \mathrm{n}=0,1 \\
& \mathrm{Z}=\mathrm{CO}, \mathrm{SO}_{2}, \mathrm{CH}_{2} \\
& \mathrm{R}=\mathrm{H} \text {, alkyl } \\
& \mathrm{n}=0 \text {, Indoles }(72-98 \%) \\
& n=1 \text {, Dihydroisoquinolines (56-82\%) } \\
& \text { [RuCl} 2 \text { (p-cymene) }]_{2} \text { (2 mol\%) } \\
& \begin{array}{c}
\mathrm{PBu}_{3}(6 \mathrm{~mol} \%) \\
\text { toluene, } \Delta \\
45 \%
\end{array} \\
& \text { 5-exo }
\end{aligned}
$$
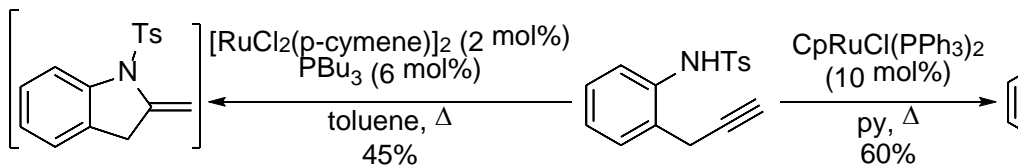

Scheme 22

These results may be interpreted in terms of the proposed mechanism shown in Scheme 23. Dissociation of $\mathrm{Cl}^{-}$from the starting $\mathrm{Ru}$ precatalyst is followed by coordination of the alkyne and subsequent rearrangement leads to Ru vinylidene intermediate I. This key intermediate may undergo nucleophilic attack by the pendant amine or amide with concurrent removal of a proton by pyridine to provide the alkenyl Ru species II. Finally, protonolysis by the pyridinium salt formed could provide the final indoles or dihydroisoquinolines, with regeneration 
of the active catalytic species. A similar mechanistic proposal could be invoked for the preparation of dihydroquinolines from bis-homopropargylic amide.

$\mathrm{CpRuL}{ }_{2} \mathrm{Cl}$

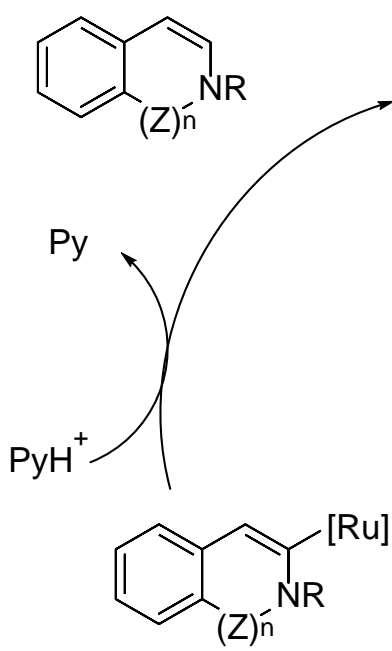

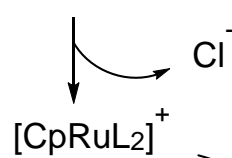<smiles>[R]NNc1cc(CC)ccc1C#C</smiles>

(Z)́n

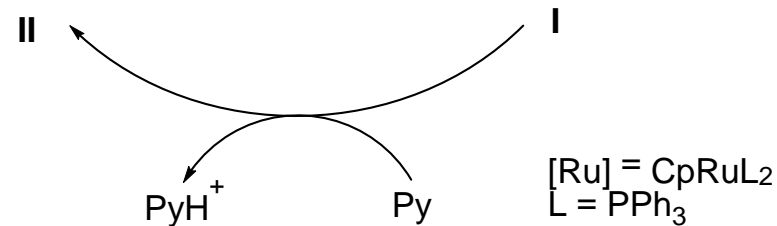

Scheme 23

Phosphorus nucleophiles can also be added to $\mathrm{C} \alpha$ of ruthenium vinylidenes. Dixneuf and co-workers reported the efficient Ru-catalyzed anti-Markovnikov cis hydrophosphination of propargyl alcohols to vinyl phosphines (Scheme 24).[53]

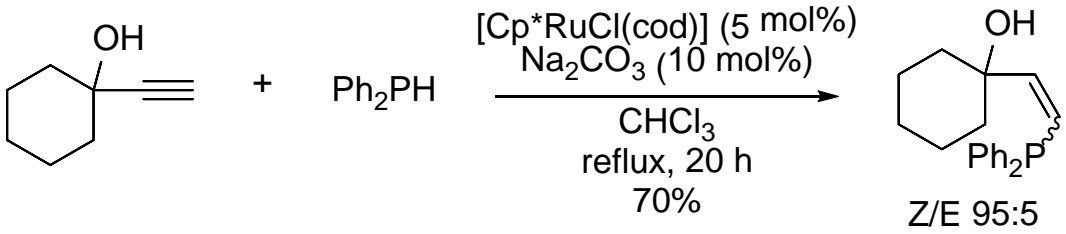

\section{Scheme 24}

\subsection{C-Nucleophiles}

Ruthenium vinylidenes can participate in the formation of $\mathrm{C}-\mathrm{C}$ bonds by using carbon nucleophiles that are capable of adding to the electrophilic $\mathrm{C} \alpha$ to the metal. 
Head-to-head dimerization of alkynes can be rationalized by the intramolecular attack of the Csp of one catalytic alkynylrutheniumvinylidene species I, generated in situ by treatment of one alkyne with catalytic amounts of a ruthenium complex, followed by acidic protonolysis of the intermediate enynyl II to afford the conjugated enyne (Scheme 25).[54] Depending on the nature of the ligands, complex II can rearrange to a cumulenyl ruthenium species III, which upon protonolysis gives the butatriene compound (Scheme 25).[55]

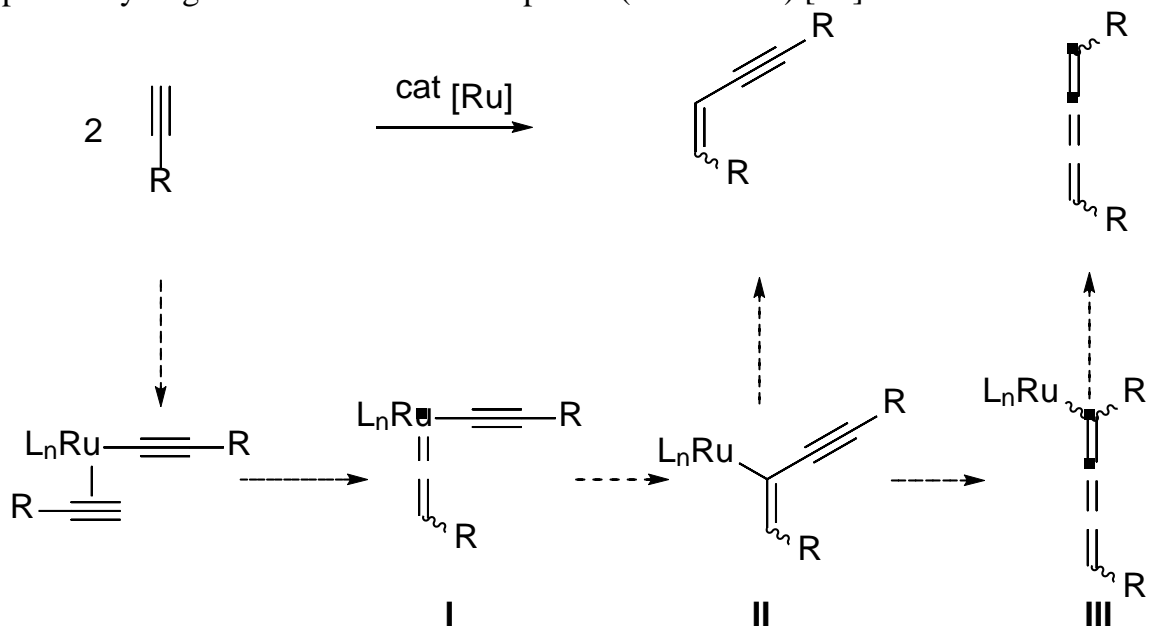

Scheme 25

There have been several reports of ruthenium complexes that are able to catalyze the head-to-head dimerization of alkynes with different $E / Z$ selectivities. These compounds include [TpRuCl( $\left.\left.\mathrm{PPh}_{3}\right)_{2}\right],[56] \quad[\mathrm{TpRu}(\mathrm{Mei}-$ $\left.\left.\mathrm{Pr}_{2} \mathrm{P}\right) \mathrm{C}(\mathrm{Ph})=\mathrm{C}(\mathrm{Ph}) \mathrm{CCPh}\right],[57] \quad\left[\mathrm{Ru}\left(\mathrm{ma}_{2}\left(\mathrm{PPh}_{3}\right)_{2}\right] \quad(\mathrm{ma}=\right.$ maltolate, $\left.\mathrm{C}_{6} \mathrm{H}_{5} \mathrm{O}_{3}\right),[58]\left[\left(\eta^{5}-\mathrm{C}_{9} \mathrm{H}_{7}\right) \mathrm{Ru}\left(\mathrm{PPh}_{3}\right)_{2} \mathrm{CCPh}\right],[59] \quad\left[\mathrm{RuCl}_{2}\left(\mathrm{PCy}_{3}\right)_{2}=\mathrm{CHPh}\right][60]$ and $\mathrm{RuHXL}_{2}\left[\mathrm{X}=\mathrm{Cl}\right.$ or N($\left(\mathrm{SiMe}_{3}\right)_{2}, \mathrm{~L}=\mathrm{Pi}^{\left.-\mathrm{Pr}_{3}\right] .[61]}$

The stereoselectivity of the dimerization process can be modulated by changing the nature of the ligands in the catalysts. $\mathrm{Yi}$ and Liu reported that the use of [Cp* $\left.\mathrm{Ru}(\mathrm{L}) \mathrm{H}_{3}\right]\left(\mathrm{L}=\mathrm{PCy}_{3}\right)$ led to dimerization of phenylacetylene to the $\mathrm{Z}$ isomer, whereas the system with $\mathrm{L}=\mathrm{PMe}_{3}$ gave the product of $E$ configuration as the major isomer (Scheme 26).[62] More recently, Bianchini and co-workers described the synthesis of $(Z)$-enynes from aliphatic and aromatic alkynes with high regio- and stereoselectivity by using $\left[\mathrm{RuH}\left(\mathrm{CH}_{3} \mathrm{CN}\right)\left(\mathrm{NP}_{3}\right)\right] \mathrm{OTf}$ as the catalyst in both aqueous and organic media (Scheme 26).[63] 


$$
\begin{aligned}
& \mathrm{Ph} \stackrel{\text { cat } \mathrm{Cp} \mathrm{RuLH}_{3}}{\mathrm{THF}, 80^{\circ} \mathrm{C}, 24 \mathrm{~h}} \\
& \overbrace{\mathrm{Ph}}^{\mathrm{R}}+\overbrace{\mathrm{Ph}}^{\mathrm{R}} \\
& \mathrm{L}=\mathrm{PCy}_{3}: 1: 9 \text { (86\%) } \\
& \mathrm{L}=\mathrm{PMe}_{3}: 9: 1 \text { (82\%) } \\
& \mathrm{R} \rightleftharpoons \frac{\text { cat }\left[\mathrm{RuH}\left(\mathrm{NCCH}_{3}\right)\left\{\mathrm{N}\left(\mathrm{CH}_{2} \mathrm{CH}_{2} \mathrm{PPh}_{2}\right)_{3}\right\}\right] \mathrm{OTf}}{\text { benzene, toluene or neat, } \Delta} \\
& \mathrm{R}=\mathrm{Ph}, n_{\mathrm{C}_{6}} \mathrm{H}_{13}, t-\mathrm{Bu}
\end{aligned}
$$

\section{Scheme 26}

It was also possible to achieve cross-dimerization with (Z)-selectivity of two types of alkynes that possess significantly different properties with respect to the tautomerization between alkyne and vinylidene ligands. Cross-dimerization of arylacetylenes and silylacetylenes was reported to proceed on using vinylideneruthenium complexes bearing bulky and basic trialkyl phosphine ligands in the presence of methylpyrrolidine (Scheme 27).[64]

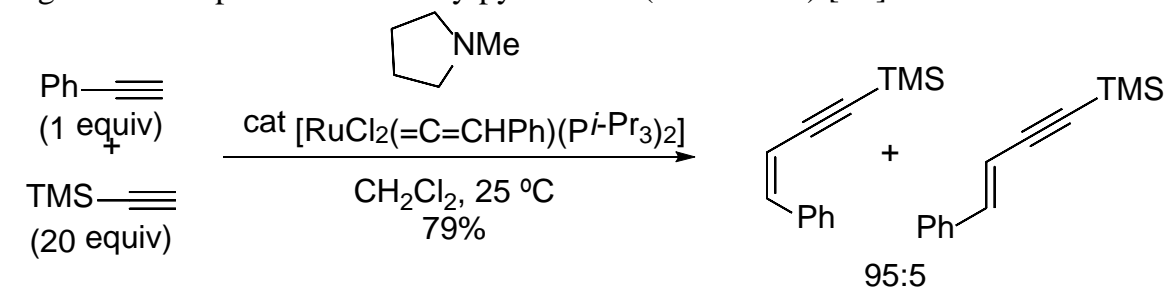

\section{Scheme 27}

In addition to dimerization and cross-dimerization of alkynes, regio- and stereoselective polyaddition of alkynes catalyzed by ruthenium has also been described. Katayama and Ozawa reported the synthesis of poly(9,9-dioctyl-2,7fluorene ethynylene vinylene) having $(Z)$-vinylene units by polyaddition of 2,7diethynyl-9,9-dioctylfluorene catalyzed by $\mathrm{RuCl}_{2}(=\mathrm{C}=\mathrm{CHPh})\left(\mathrm{Pi}-\mathrm{Pr}_{3}\right)_{2}$ (Scheme 28).[65] 
<smiles>C#Cc1ccc2c(c1)C(CCCC)(CCCC)c1cc(C#C)ccc1-2</smiles>

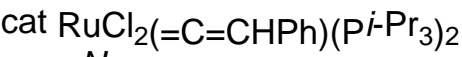
$N_{\text {-methylpyrrolidine }}$

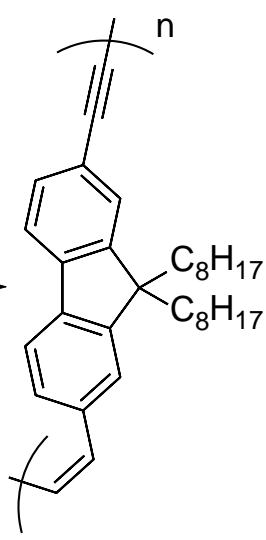

$92 \%, Z$

Scheme 28

Alkenes are also capable of acting as nucleophiles and can add intramolecularly to ruthenium vinylidenes. Liu and co-workers described the $\mathrm{TpRu}\left(\mathrm{PPh}_{3}\right)\left(\mathrm{CH}_{3} \mathrm{CN}\right)_{2} \mathrm{PF}_{6}$-catalyzed cycloisomerization of substituted orthoalkynylethynylstyrenes to give different naphthalenes or indenes depending on the nature of the alkene substituents (Scheme 29).[66] In all cases the reaction begins with the formation of the ruthenium vinylidene I. Subsequent 6-endo-dig (path a) or 5-endo-dig (path b) cyclization by nucleophilic attack of the alkene moiety would afford ruthenium species II and III, respectively. When monosubstituted iodoalkenes were used, only path a is operative, while with aryl monosubstituted alkenes the most favorable path was b. The substituted naphthalenes were obtained after a final rearrangement.[66a] Both mechanisms are operative when terminal disubstituted alkenes are used, with the naphthalene derivatives obtained from 6-endo-dig cyclization and indenes from 5-endo-dig cyclization.[66b] 


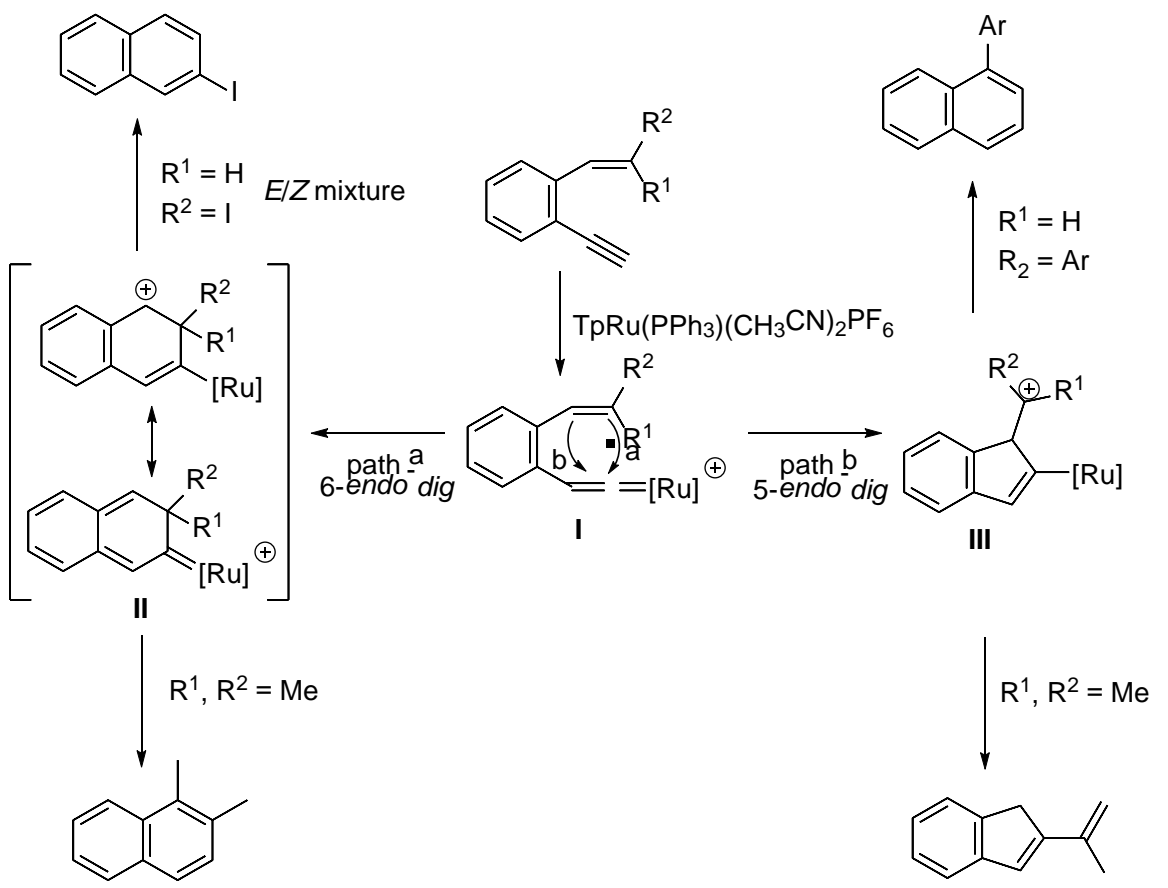

\section{Scheme 29}

Non-conjugated terminal 2-substituted-1,5-enynes also react through a 6-endo-dig cyclization to afford 1,3-cyclohexadienes via ruthenium vinylidene intermediates. Nishibayashi and co-workers reported that 2-substituted-1,5-enynes in the presence of $5 \%$ methanethiolate-bridged diruthenium complex $\left[\mathrm{Cp} * \mathrm{RuCl}\left(\mu_{2^{-}}\right.\right.$ $\mathrm{SMe})]_{2}$ and $10 \mathrm{~mol} \%$ of $\mathrm{NH}_{4} \mathrm{BF}_{4}$ afforded the corresponding 1,3-cyclohexadienes in good yields (Scheme 30).[67] 


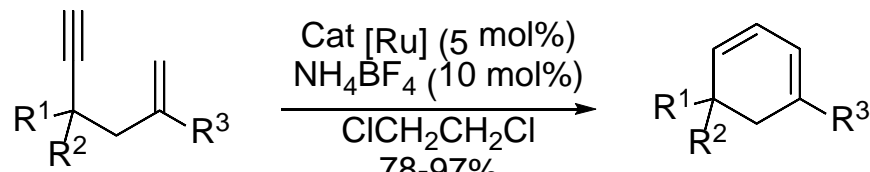

$\mathrm{R}^{1}=\mathrm{Et}, n \mathrm{Pr}, \mathrm{Ph}$

$\mathrm{R}^{2}=\mathrm{Me}, \mathrm{Et}, \mathrm{H}$

$\mathrm{R}^{3}=\mathrm{Ar}, \mathrm{BBu}$

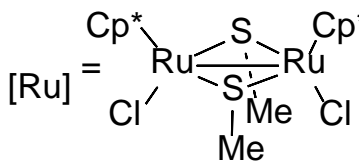

$78-97 \%$

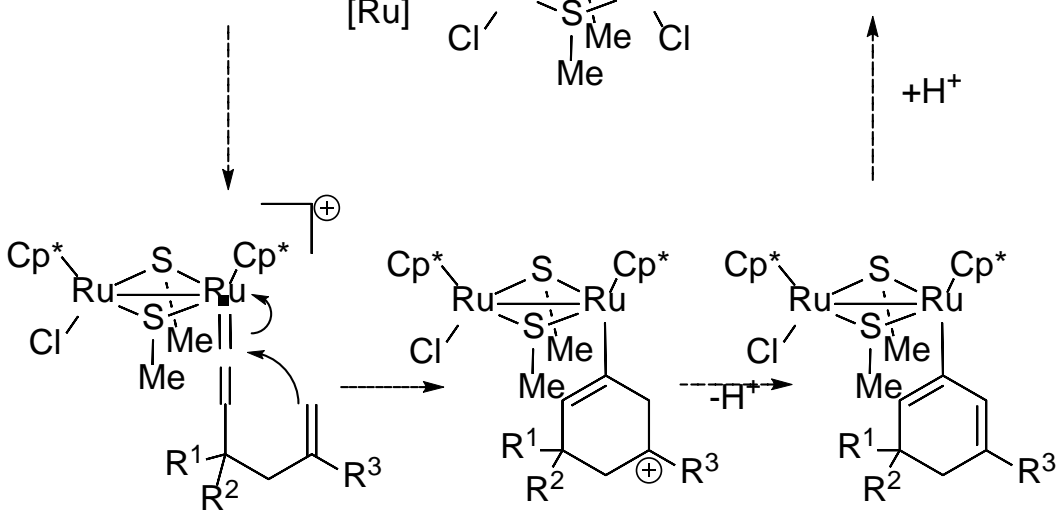

Scheme 30

Lin and co-workers described the 6-endo-dig cyclization of aromatic 1,5-enynes incorporating a cycle catalyzed by $\left.\left[\mathrm{CpRu}\left(\mathrm{PPh}_{3}\right)_{2} \mathrm{CH}_{3} \mathrm{CN}\right)\right]^{+}$using a mixture of $\mathrm{CHCl}_{3} / \mathrm{MeOH}$ to afford fused tricyclic rings with the incorporation of $\mathrm{MeOH}$ (Scheme 31).[68] Interestingly, the position of the final double bond varies depending on the size of the ring bearing the enyne.

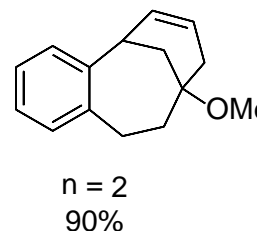<smiles>C=C1CC(C)c2cc(C(C)C)ccc2C1=NOc1ccc(C(C)C)cc1</smiles>
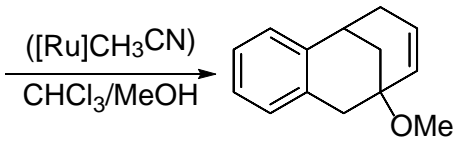

$\mathrm{n}=1$

$73 \%$

$[\mathrm{Ru}]=\mathrm{CpRu}\left(\mathrm{PPh}_{3}\right)_{2}$

Scheme 31

\subsection{B-Nucleophiles}

Ruthenium hydride pincer complex $\left[\mathrm{Ru}(\mathrm{PNP})\left(\mathrm{H}_{2}\left(\mathrm{H}_{2}\right)\right][\mathrm{PNP}=1\right.$,3-bis(di-tertbutyl-phosphinomethyl)pyridine] and its borane analog $\left[\mathrm{Ru}(\mathrm{PNP})(\mathrm{H})_{2}(\mathrm{HBpin})\right]$ $($ HBpin $=$ pinacolborane $)$ catalyze the hydroboration of terminal alkynes to give 
selectively Z-vinylboronates in high yields (Scheme 32).[69] Mechanistic studies suggest a 1,2-hydrogen shift from a $\eta^{2}$-alkyne to a vinylidene complex prior to the C-B bond formation.

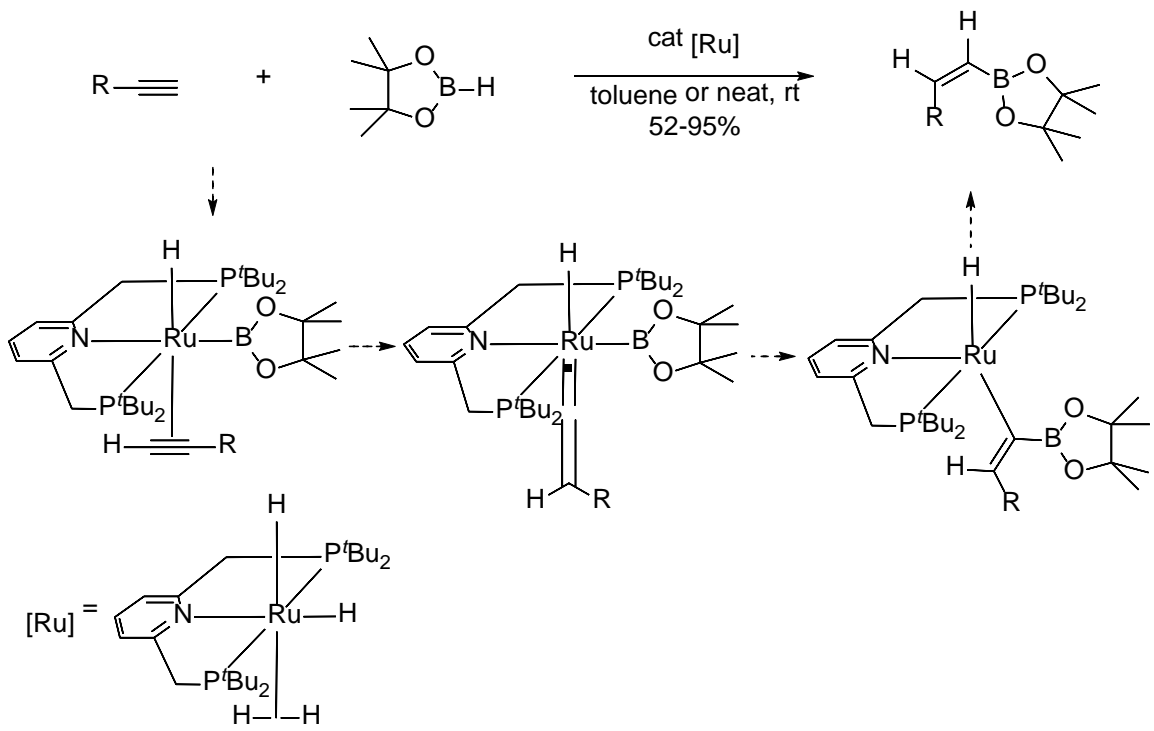

Scheme 32

\section{Intramolecular Cyclizations}

Cyclizations can be initiated by a nucleophilic attack, e.g. by $\mathrm{H}_{2} \mathrm{O}$ or a carboxylic acid, to a catalytic ruthenium vinylidene followed by trapping with an electrophile. Lee and co-workers described the Ru-catalyzed hydrative cyclization of 1,5-enynes (Scheme 33) to give functionalized cyclopentanones.[70] Treatment of 1,5-enynes bearing an internal Michael acceptor with a catalytic amount of $\left[\mathrm{Ru}_{3} \mathrm{Cl}_{5}(\mathrm{dppm})_{3}\right] \mathrm{PF}_{6}$ in the presence of water initially afforded the corresponding ruthenium vinylidene species. Nucleophilic anti-Markovnikov addition of water would afford an acylruthenium hydride, which through a hydroacylation or a Michael addition would give rise to the hydrated cycle cyclopentanone. 


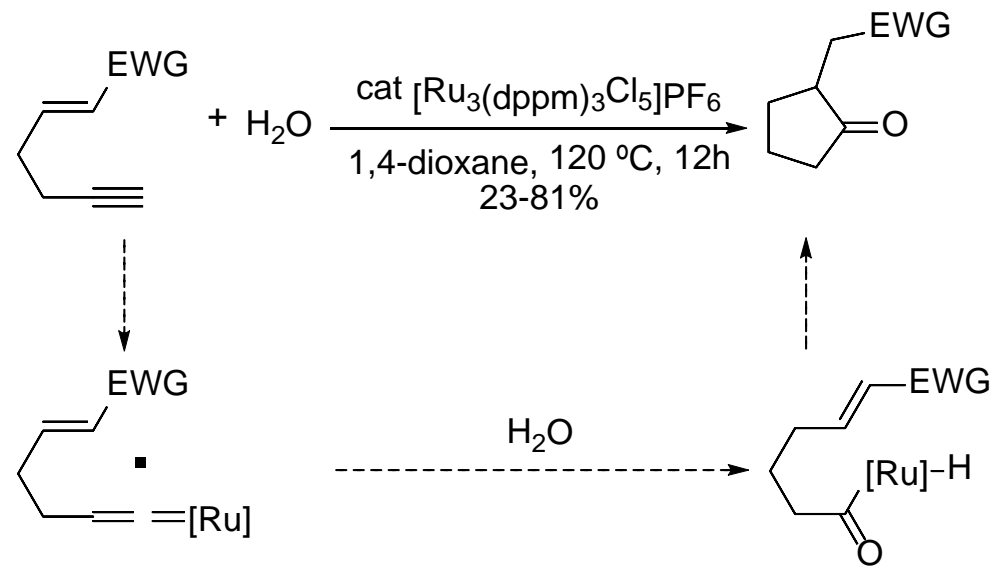

\section{Scheme 33}

Cyclization of terminal alkynals to cycloalkenes with loss of a carbon atom through catalytic ruthenium vinylidenes using $\left[\mathrm{CpRuMeCN}_{3}\right] \mathrm{PF}_{6}$ as catalyst has been described by Saá and co-workers (Scheme 34).[71] These transformations would be initiated by the nucleophilic attack of acetate to the ruthenium vinylidene I to give complex II followed by an aldol-type condensation to afford the acyl ruthenium hydride III. Finally, decarbonylation to IV followed by reductive elimination would give rise to the final product, with the terminal carbon of the alkyne being the one that is lost as CO. The use of a catalyst bearing a bidentate ligand such as $\mathrm{CpRu}(\mathrm{dppm}) \mathrm{Cl}$ prevents the decarbonylative step and this process gives the corresponding $\alpha, \beta$-unsaturated aldehyde (Scheme 34 ). 

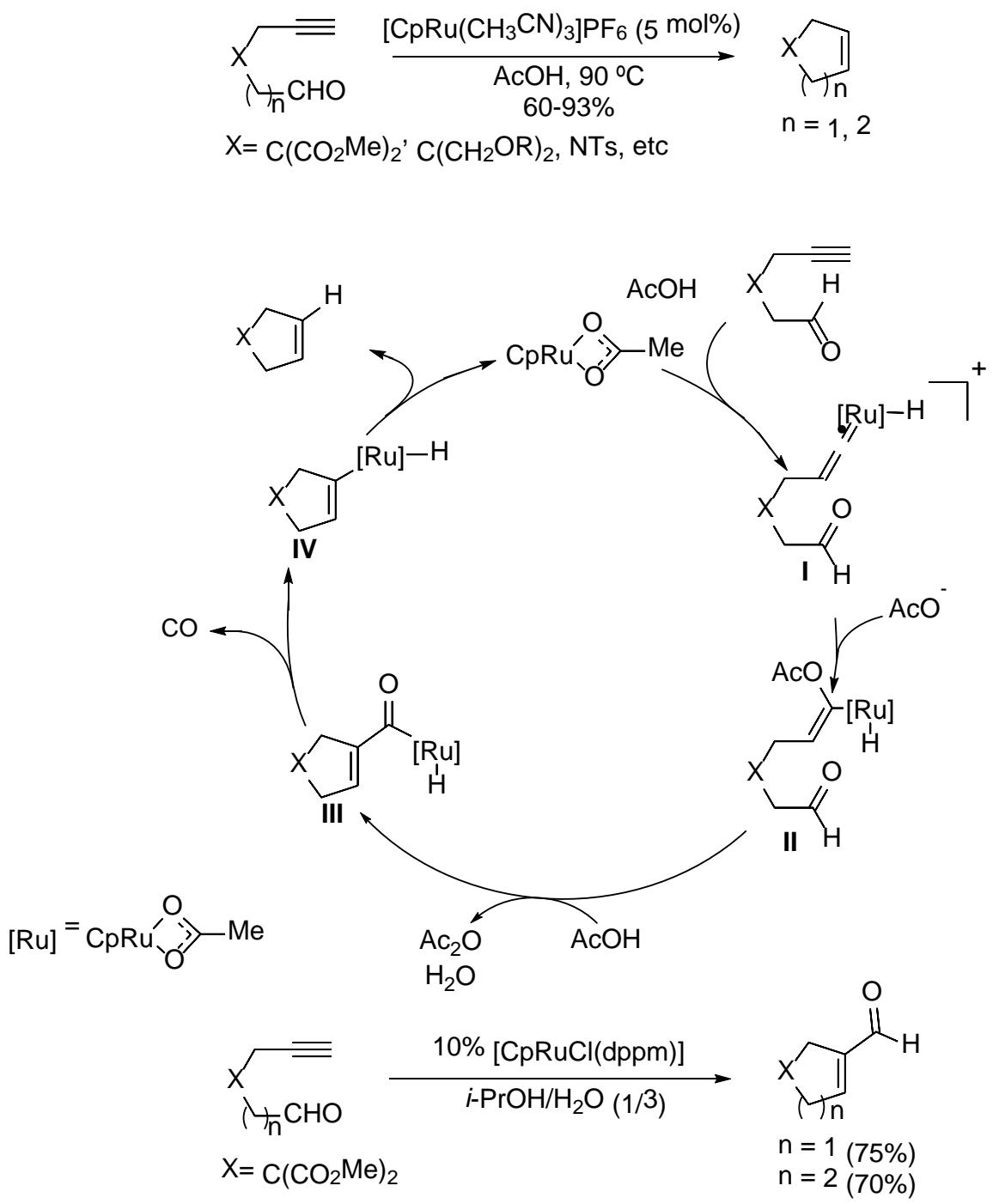

Scheme 34

The same catalyst, [CpRuMeCN$\left.{ }_{3}\right] \mathrm{PF}_{6}$, also performs the decarbonylative cyclization of 1,6-diynes to exo-alkylidenecyclopentanes through the initial addition of the carboxylic acid to a catalytic ruthenium vinylidene (Scheme 35).[72] The acyclic vinylruthenium hydride II obtained by addition of acetic acid to the initially formed vinylidene would evolve through a [3+2]-type cycloaddition to a cyclic carbene ruthenium-hydride III. Reductive loss of AcOH from III would give the cyclic carbene IV, which undergoes another nucleophilic attack by $\mathrm{AcOH}$ to give the acyl ruthenium-hydride $\mathbf{V}$. Reductive opening of ruthenacycle $\mathbf{V}$ followed by oxidative addition of $\mathrm{AcOH}$ with concomitant 
decarbonylation of VI would lead to the ruthenium-hydride VII, which affords the observed alkylidenecyclopentane through a reductive elimination (Scheme 35).

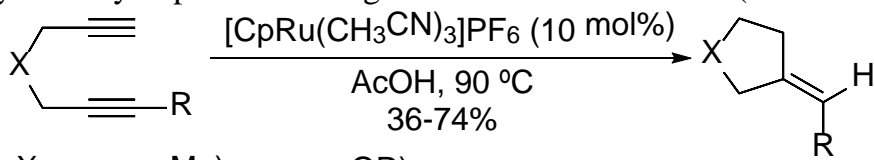

$\mathrm{X}=\mathrm{C}\left(\mathrm{CO}_{2} \mathrm{Me}\right)_{2}, \mathrm{C}\left(\mathrm{CH}_{2} \mathrm{OR}\right)_{2}, \mathrm{NTs}$, etc

$\mathrm{R}=\mathrm{H}$, Alkyl, $\mathrm{Ph}, \mathrm{CH}_{2} \mathrm{OMe}, \mathrm{CO}_{2} \mathrm{Me}$, etc

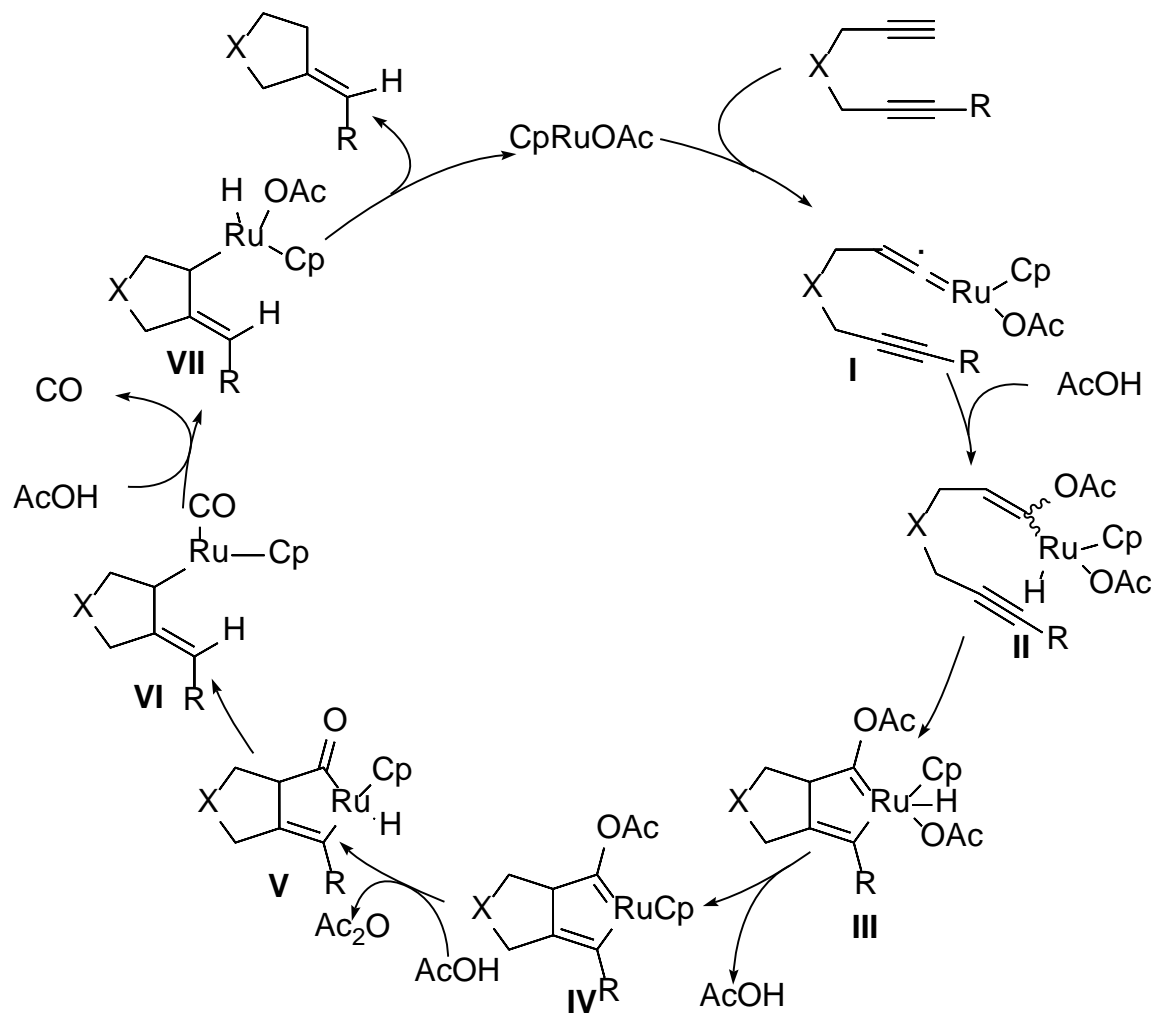

\section{Scheme35}

Variation of the electronic and steric nature of the ruthenium catalysts allow the complementary carboxylative cyclization of 1,6-diynes (Scheme 36).[73] Lee and co-workers described how a variety of carboxylic acids condense with 1,6terminal diynes in the presence of catalytic amounts of $\left[\mathrm{Ru}(p \text {-cymene }) \mathrm{Cl}_{2}\right]_{2}, \mathrm{P}(4$ $\left.\mathrm{F}_{-} \mathrm{C}_{6} \mathrm{H}_{5}\right)_{3}$ and 4-dimethylaminopyridine to give cyclohexylidene enol carboxylates with exclusive $(E)$-selectivity. The proposed mechanism involves the initial formation of a ruthenium vinylidene species $\mathbf{I}$ followed by intramolecular cyclization induced by the nucleophilic attack of the carboxylate anion to afford a 
vinylruthenium species II. Final protonolysis furnished the product and turns the catalyst over.

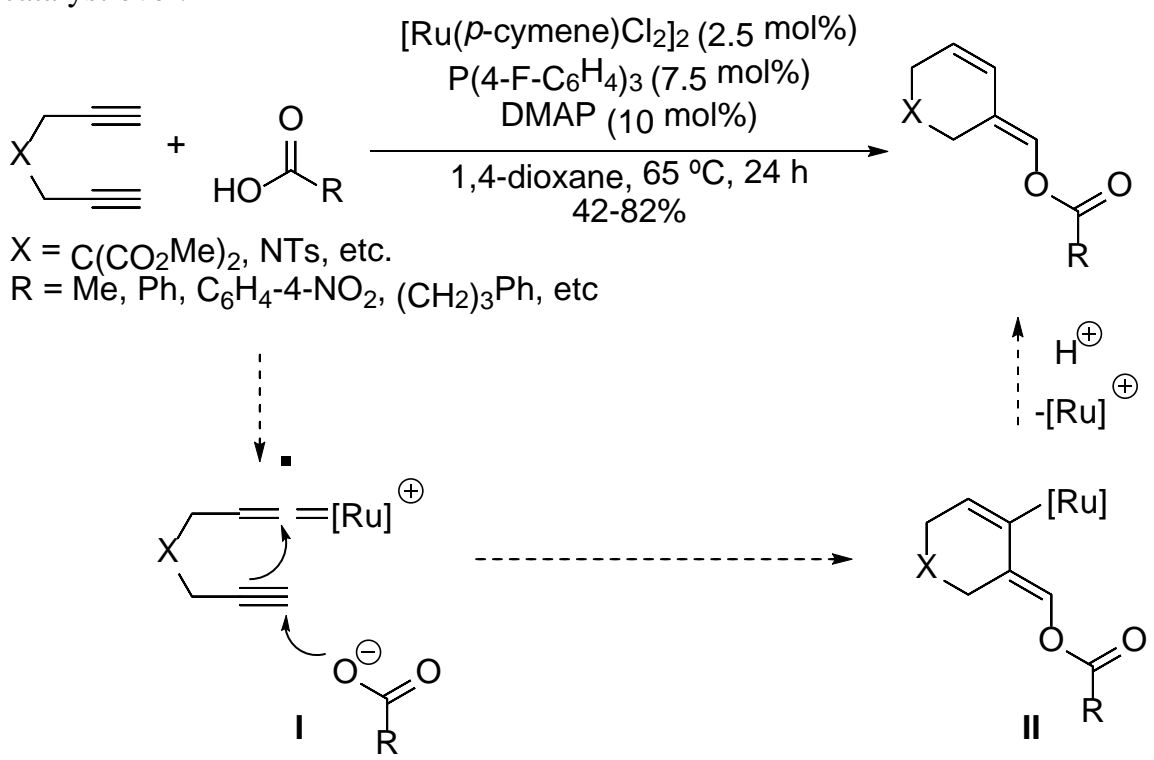

Scheme 36

\section{Pericyclic Reactions}

The electronic $\pi$ system of ruthenium vinylidenes can participate in pericyclic reactions such as electrocyclizations, cycloadditions and sigmatropic reactions to afford a variety of interesting poly(hetero)cyclic products.

\subsection{Electrocyclizations}

The first example of the participation of the electronic $\pi$ system of a catalytic ruthenium vinylidene in a $6 \mathrm{e}^{-} \pi$ electrocyclization was described by Merlic and Pauly. Treatment of conjugated terminal dienynes with catalytic amounts of $\mathrm{RuCl}_{2}$ (p-cymene) $\mathrm{PPh}_{3}$ and $\mathrm{NH}_{4} \mathrm{PF}_{6}$ in refluxing dichloromethane afforded the aromatic benzene derivatives in good yields (Scheme 37).[74] The proposed mechanism begins with the formation of the conjugated ruthenium vinylidene $\mathbf{I}$, which undergoes a $6 \mathrm{e}^{-} \pi$ electrocyclization to the ruthenium carbene II. Subsequent $\beta$-hydride elimination followed by reductive elimination would generate the benzene derivative with recovery of the Ru catalyst. 


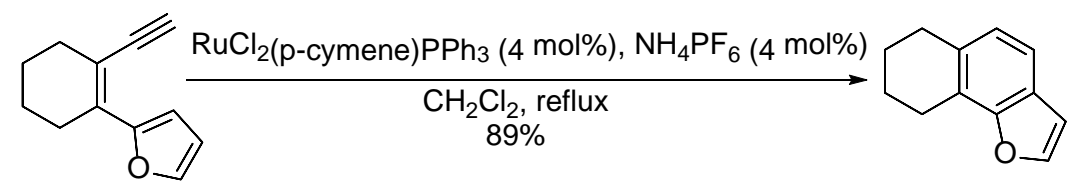

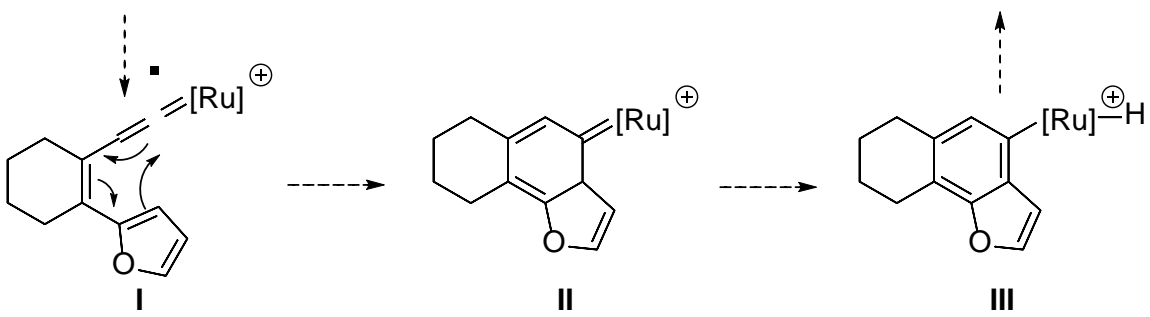

Scheme 37

Liu and co-workers reported a Ru-catalyzed 6-endo-dig cyclization of 3,5-dien-1ynes to rearranged toluene derivatives through a cascade process initiated by the formation of ruthenium vinylidenes (Scheme 38).[75]<smiles>C#CC1=C(C=C2Cc3ccccc3C2)CCC1</smiles>

$[\mathrm{Ru}]=\mathrm{TpRuPPh}_{3}\left(\mathrm{CH}_{3} \mathrm{CN}\right)_{2} \mathrm{PF}_{6}$

Scheme 38

The proposed mechanism for this transformation would start with a $6 \mathrm{e}^{-} \pi$ electrocyclization of ruthenium vinylidene I to cyclic dienylcarbene II (Scheme 39). A 1,2-alkyl shift in carbene II would afford the rearranged cationic intermediate III. Attack of the ruthenium center of species III at the remote benzyl carbon with a concomitant 1,2-phenyl shift would give rise to the cyclobutylruthenium species IV. Another structural rearrangement from a [1,5]sigmatropic alkyl shift would afford the cyclobutylruthenium $\mathbf{V}$, which would ultimately give rise to the observed polycyclic toluene derivatives. 


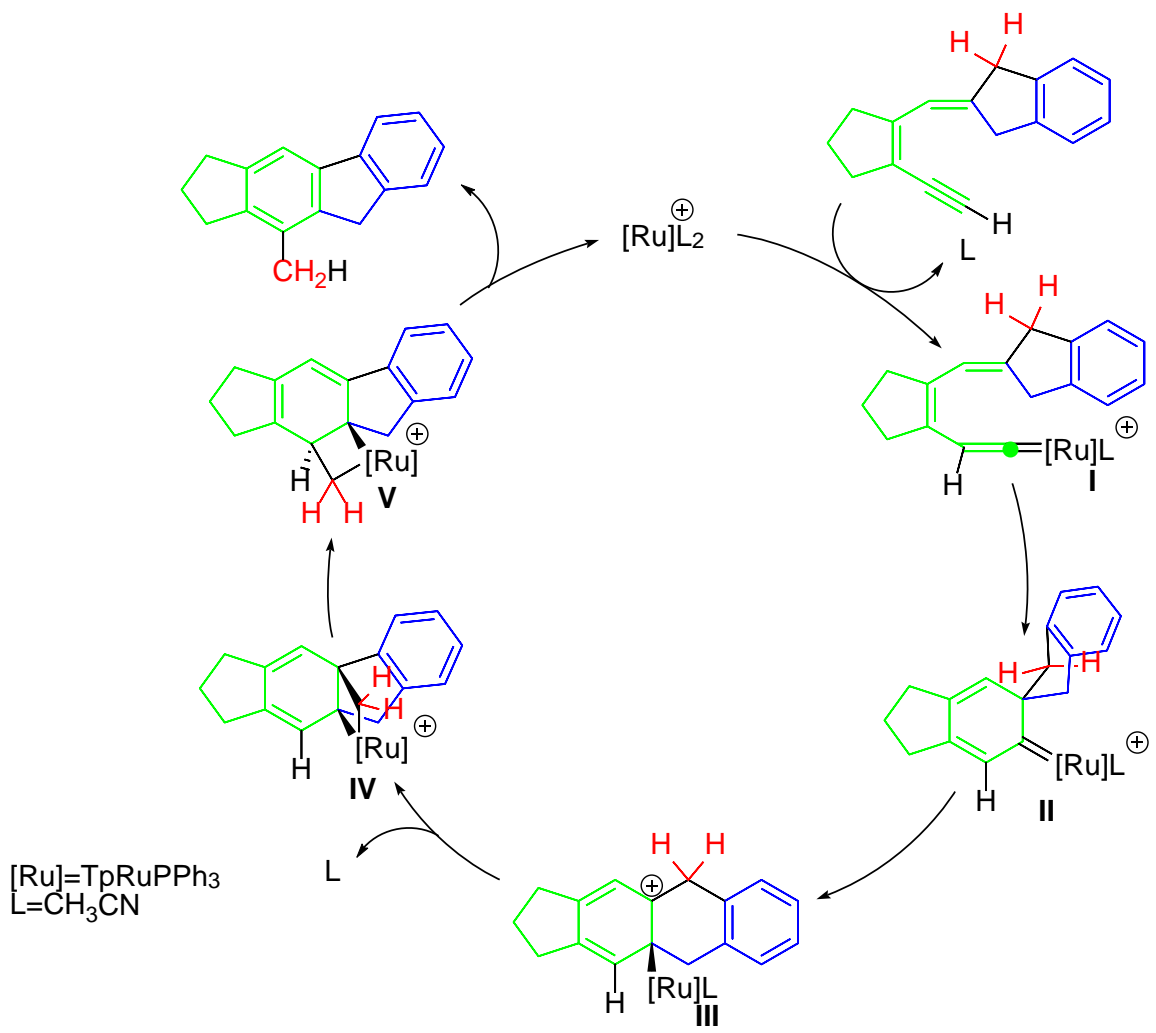

Scheme 39

Similarly, $\alpha$-pyridones and 3(2H)-isoquinolones have been synthesized from 3en-5-ynyl nitrones and o-alkynylphenyl nitrones, respectively (Scheme 40).[76] The proposed mechanism involves an $8 \mathrm{e}^{-} \pi$-electrocyclization of the initially formed vinylidene I to form seven-membered heterocyclic species II, which can also be represented as its resonance structure, the pentadienyl cation II'. Cleavage of the $\mathrm{N}-\mathrm{O}$ bond leads to species III, bearing both imine and ketene functionalities, which undergoes an $6 \mathrm{e}^{-} \pi$-electrocyclization to afford the final heterocyclic products. 
<smiles>[R][N+]([O-])=CC1=C(C#C)CCCC1</smiles>
$\mathrm{R}^{3}=\mathrm{Bn}, \mathrm{Me}$

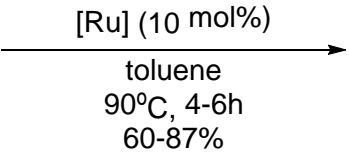

$60-87 \%$<smiles>[R]n1cc2c(cc1=O)CCC2</smiles><smiles>[R]n1cc2ccccc2cc1=O</smiles>

$[\mathrm{Ru}]=\mathrm{TpRuPPh}_{3}\left(\mathrm{CH}_{3} \mathrm{CN}\right)_{2} \mathrm{SbF}_{6}$

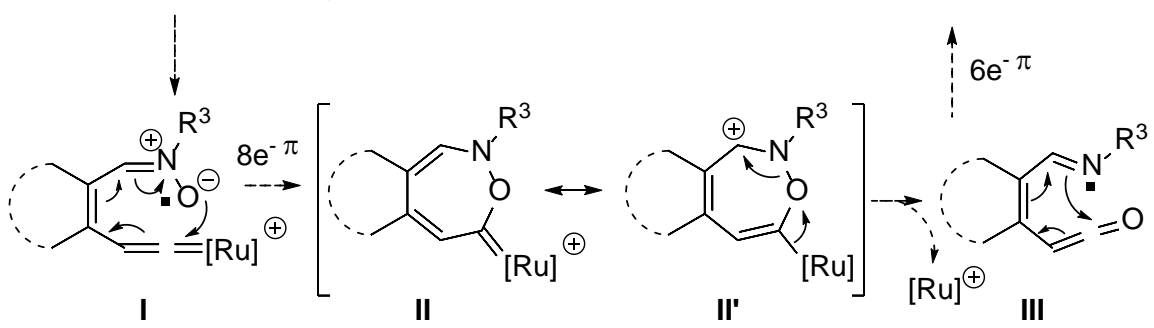

Scheme 40

\subsection{Cycloadditions}

\subsection{1. [2+2] Cycloadditions}

The $\pi$-system of ruthenium vinylidenes has been shown to participate in [2+2] cycloadditions with other unsaturated compounds. Murakami and co-workers described the formation of 1,3-dienes by reaction of phenylacetylenes with several olefins (Scheme 41, eq 1)[77] and the regio- and stereoselective alkenylation of pyridines, both catalyzed by the complex [CpRuCl( $\left.\mathrm{PPh}_{3}\right)_{2}$ ] (Scheme 41, eq 2).[78] In both cases the mechanism involves the initial formation of a ruthenium vinylidene I followed by a [2+2] cycloaddition with the double bond of either the alkene or the pyridine to afford ruthenacyclobutene species II. Finally, deprotonation and protonolysis would afford the corresponding product. 


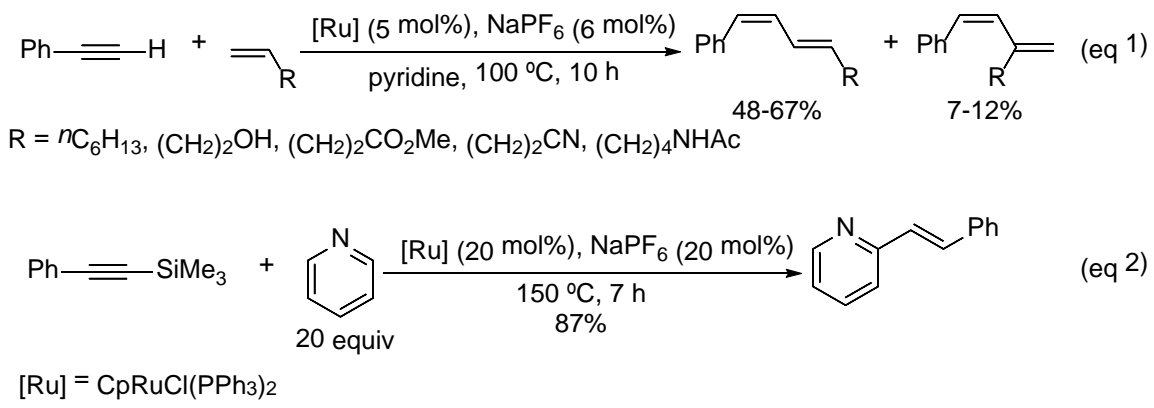

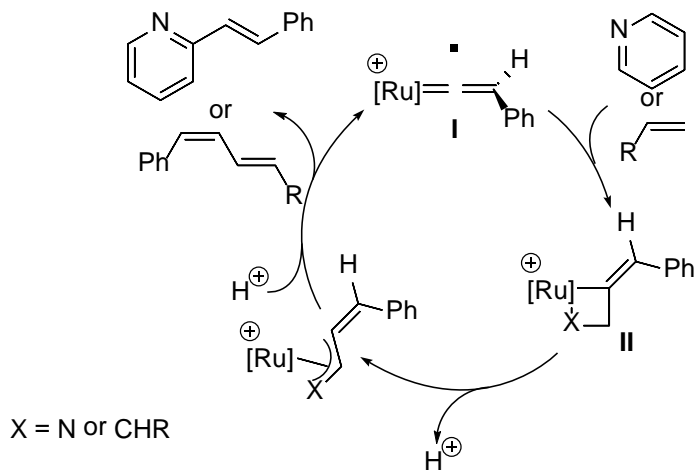

\section{Scheme 41}

Recently, Slattery and Lynam reported that the formation of 2-styrylpyridine from terminal alkynes and pyridine could also be catalyzed by the cationic ruthenium complex $\left[\mathrm{CpRuPy} 2\left(\mathrm{PPh}_{3}\right)\right] \mathrm{PF}_{6}$ under far milder conditions than the corresponding reaction promoted by $\left[\mathrm{CpRuCl}\left(\mathrm{PPh}_{3}\right)_{2}\right]$ (Scheme 42).[79] According to experimental and theoretical data, the mechanistic rationale would involve a catalytic ruthenium pyridylidene species without the formation of ruthenacyclobutenes. The initially formed ruthenium vinylidene I would undergo nucleophilic attack of the pyridine to give vinyl ruthenium II, which would evolve to pyridylidenes III and IV. C-N bond cleavage and protonation would give rise to vinylidene VI, which after $\mathrm{C}-\mathrm{C}$ bond formation by pyridylidene migration to the $\alpha$-carbon of the Ru-vinylidene would afford the 2-styrylpyridine with regeneration of the catalytic species. 


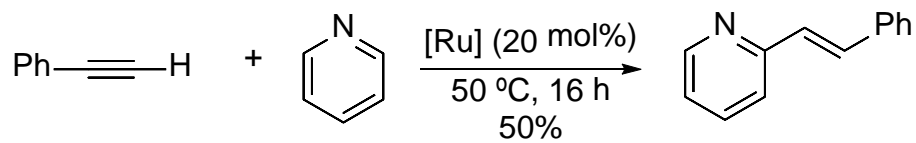

$[\mathrm{Ru}]=\left[\mathrm{CpRuPy}{ }_{2} \mathrm{PPh}_{3}\right] \mathrm{PF} 6$

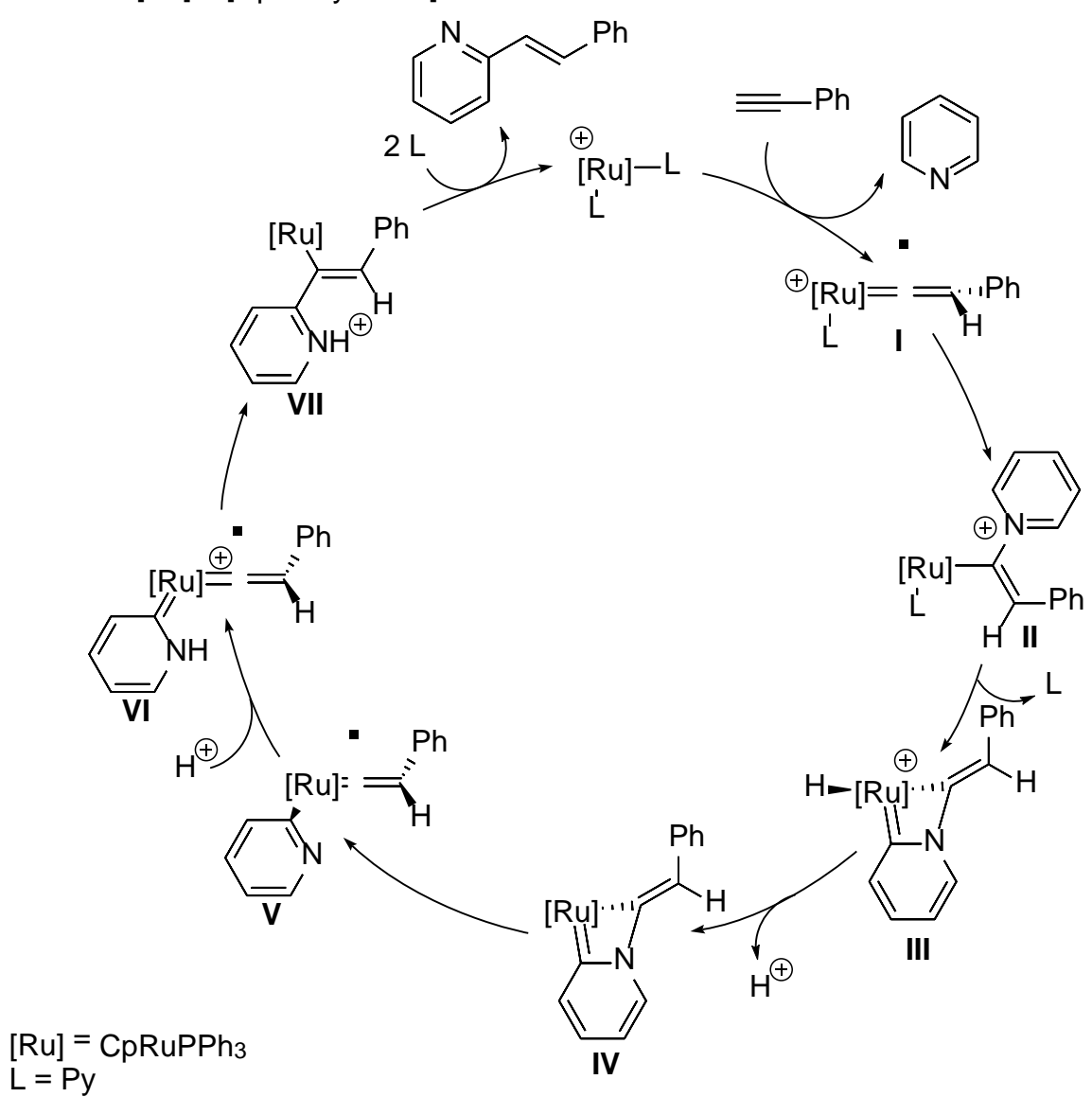

\section{Scheme 42}

\subsection{2. [4+2] Cycloadditions}

Intermolecular Diels-Alder reactions between catalytic ruthenium vinylidenes I and arylacetylenes afforded 1-arylnaphthalenes (cyclodimerization) in moderate yields (Scheme 43).[80] Tautomerization of the initial cycloadduct, ruthenium carbene II, followed by reductive elimination gives rise to the final naphthalene with regeneration of the catalytic porphyrylruthenium complex. 
<smiles>C#Cc1ccc(C)cc1</smiles>

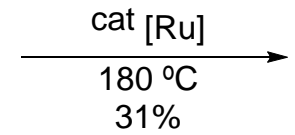<smiles>Cc1ccc(-c2cccc3ccc(C)cc23)cc1</smiles>

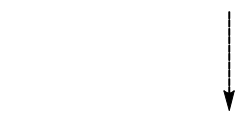<smiles>Cc1ccc(C#Cc2ccc(C)cc2)cc1</smiles>

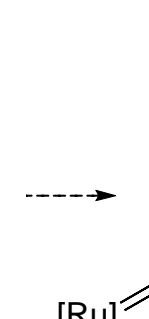<smiles>C=C1C=C2C=CC(C)=CC2C(c2ccc(C)cc2)=C1</smiles>
$\uparrow$

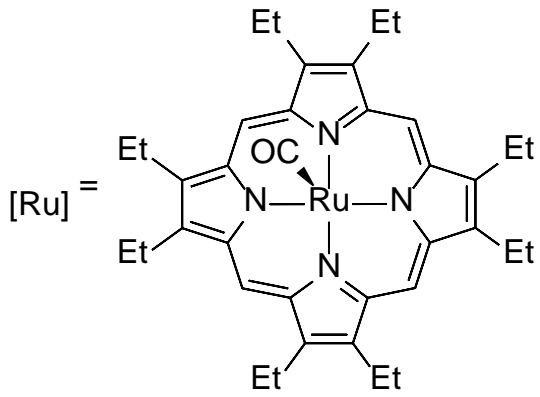

Scheme 43

\section{3. [1,5] Sigmatropic Rearrangements}

Liu and co-workers reported the cycloisomerization of cis-3-en-1-ynes to cyclopentadiene derivatives through 1,5-sigmatropic hydrogen shifts of catalytic ruthenium vinylidene intermediates (Scheme 44).[81]<smiles>C#CC(O)(CC[Al])c1ccccc1</smiles>

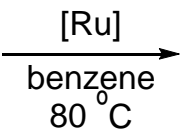<smiles>C#C/C(=C\CC[Al])c1ccccc1</smiles>

[Ru]

$[\mathrm{Ru}]=\mathrm{TpRuPPh}_{3}\left(\mathrm{CH}_{3} \mathrm{CN}\right)_{2} \mathrm{PF}_{6}$ $\mathrm{Ar}=2-\mathrm{MeOPh}$ 


\section{Scheme 44}

More recently, the cyclizations of 2-alkyl-1-ethynylbenzenes to 1-substituted-1Hindenes and 1-indanones have also been developed (Scheme 45).[82]<smiles>C#Cc1cc(OC)ccc1CCCCCCCC</smiles><smiles>CC(C)(C)[Mg][Mg]</smiles><smiles>CCCCCCCC1C=Cc2cc(OC)ccc21</smiles><smiles>C#Cc1cc(OC)ccc1C[O+]S</smiles><smiles>CC(C)[Mg][Mg][Mg]</smiles><smiles>COc1ccc2c(c1)CCC2=O</smiles>

$$
[\mathrm{Ru}]=\mathrm{TpRuPPh}_{3}\left(\mathrm{CH}_{3} \mathrm{CN}\right)_{2} \mathrm{PF}_{6}
$$

\section{Scheme 45}

In both cases the proposed mechanism would start with the formation of vinylidene I that evolves to the carbene II by a [1,5]-hydrogen shift. Subsequent $6 \mathrm{e}^{-} \pi$-electrocyclization of II to ruthenacyclohexadiene III followed by reductive elimination would afford the final product (Scheme 46).<smiles>[R]C1C=Cc2ccccc21</smiles>

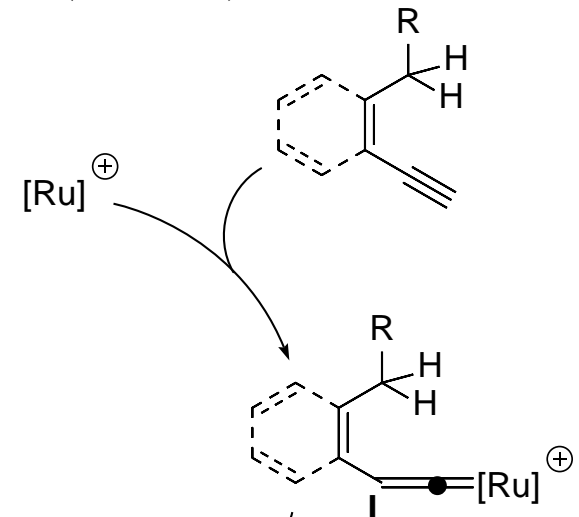

$[\mathrm{Ru}]=\mathrm{TpRuPPh}_{3}\left(\mathrm{CH}_{3} \mathrm{CN}\right)_{2} \mathrm{PF}_{6}$

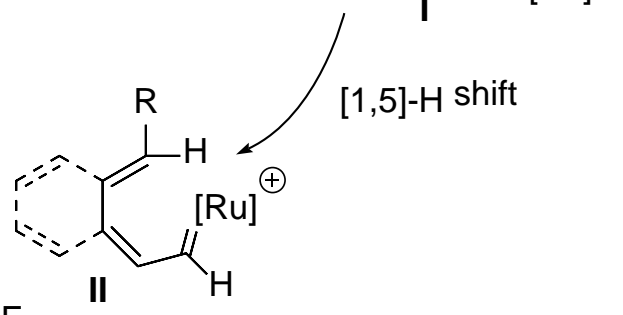

\section{Scheme 46}




\section{Vinylideneruthenium Catalysts in Metathesis}

Some ruthenium vinylidene complexes have been found to serve as good catalyst precursors for olefin metathesis.[83] Although the efficiency of the vinylidene complexes as initiators is lower than those of the well-known Grubbs' alkylidene and indenylidene complexes, the polymerization rate is fast enough for practical use and, more importantly, they are readily prepared from conventional terminal alkynes. Another important feature is the rearrangement of the vinylidene ligand $([\mathrm{M}]=\mathrm{C}=\mathrm{CHR})$ to an alkylidene moiety $([\mathrm{M}]=\mathrm{CHR})$ in the presence of an olefin, a process that allows the application of vinylidenes as precursors for selective crossmetathesis $(\mathrm{CM})$, ring-closing metathesis (RCM) and ring-opening metathesis polymerization (ROMP).[84] Specifically, the use of vinylideneruthenium as a catalyst in metathesis has been subject of several recent reviews.[12c-e,k]

Since the first use of $\left[\mathrm{RuCl}_{2}\left(=\mathrm{C}=\mathrm{CH}_{2}\right)\left(\mathrm{PCy}_{3}\right)_{2}\right]$ as a catalyst for ROMP,[85] several analogs containing other phosphines (such as $\mathrm{PPh}_{3}$ and $\mathrm{Pi}_{-} \mathrm{Pr}_{3}$ ) and vinylidene ligands generated from various alkynes (such as tert-butylacetylene, phenylacetylene, ferrocenylacetylene, para-methoxyphenylacetylene) as well as $\mathrm{TpRuCl}(=\mathrm{C}=\mathrm{CHPh})\left(\mathrm{PPh}_{3}\right)$ have been used to catalyze the ROMP of a variety of norbornene derivatives and in the RCM of $\alpha, \omega$-dienes (Scheme 47).[84,86]

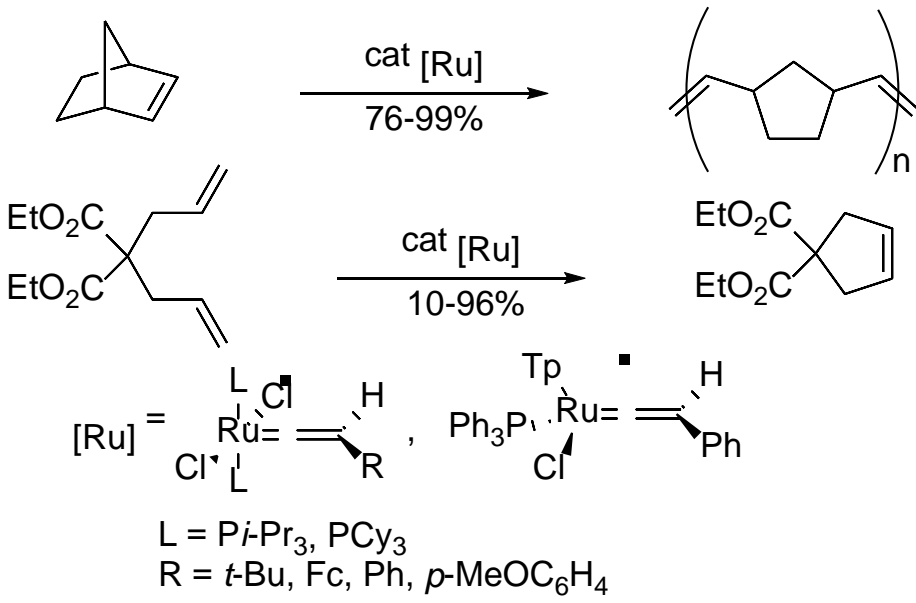

\section{Scheme 47}

Replacement of a phosphine ligand with an $\mathrm{N}$-heterocyclic carbene (NHC) increases the stability and efficiency of the catalyst precursors, thus affording a second generation of monometallic ruthenium initiators. Several vinylidene complexes $\left[\mathrm{RuCl}_{2}(=\mathrm{C}=\mathrm{CHR})\left(\mathrm{PCy}_{3}\right)(\mathrm{NHC})\right]$ bearing mixed ligand sets made up of tricyclohexylphosphine $\left(\mathrm{PCy}_{3}\right)$ and $N$-heterocyclic carbenes promoted several RCM and ROMP reactions (Scheme 48).[87] 


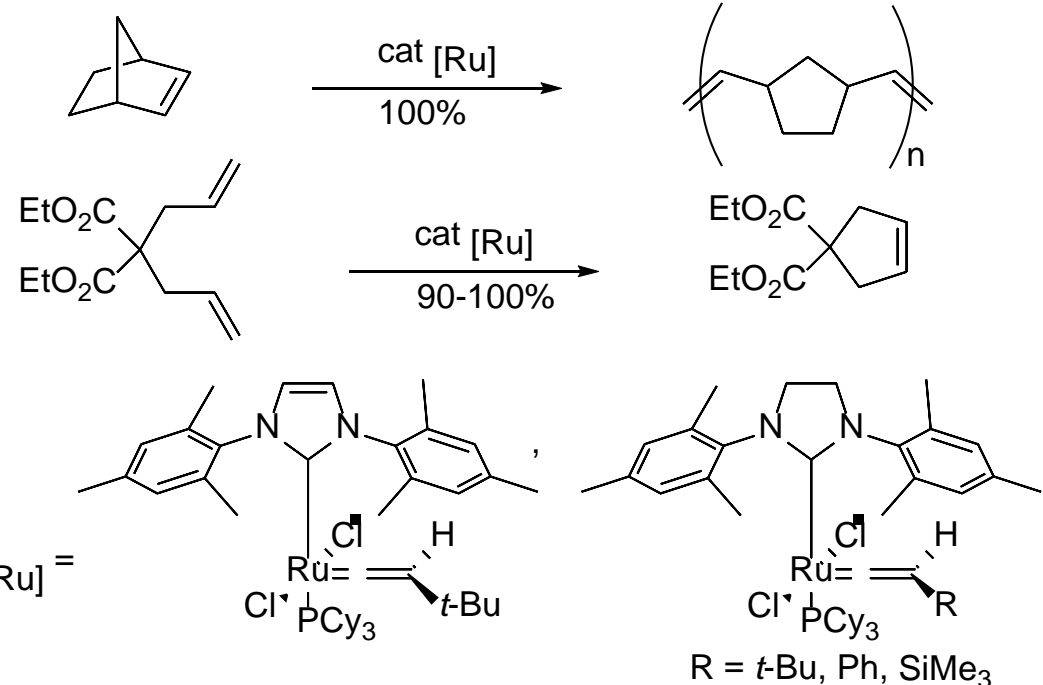

\section{Scheme 48}

More recently, Delaude and co-workers described the catalytic application in olefin metathesis of new homobimetallic ruthenium arene complexes bearing vinylidene ligands. The complex $\left[(p\right.$-cymene $\left.) \mathrm{Ru}(\mu-\mathrm{Cl})_{3} \mathrm{RuCl}(=\mathrm{C}=\mathrm{CHPh})\left(\mathrm{PC} y_{3}\right)\right]$ was synthesized and tested in metathesis reactions. Although its reaction with norbornene afforded high molecular weight polymers almost quantitatively, for the ROMP of cyclooctadiene it was necessary to use aluminum chloride as a cocatalyst. For the RCM of 1,6-dienes it was also necessary to use a cocatalyst, in this case phenylacetylene (Scheme 49).[88] Homobimetallic ruthenium arene complexes bearing NHC instead of phosphine ligands were also reported as catalysts for metathesis. This second generation of homobimetallic ruthenium arene complexes displayed an enhanced metathetical activity in both the ROMP of cyclooctene and the RCM of 1,6-dienes (Scheme 49).[89] 


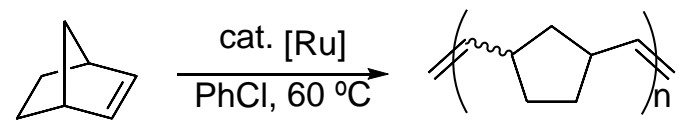

$[\mathrm{Ru}]^{1^{\text {st }} \text { Generation } 80 \%}$

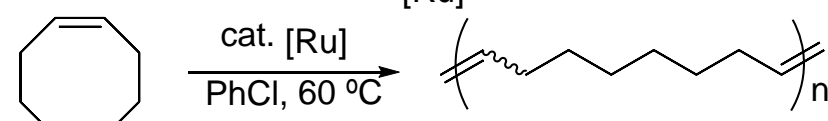

$[\mathrm{Ru}] 1^{\text {st }}$ Generation $+\mathrm{AlCl}_{3}$ as cocatalyst $84 \%$

$[\mathrm{Ru}] 2^{\text {nd }}$ Generation $87 \%$ (no cocatalyst)

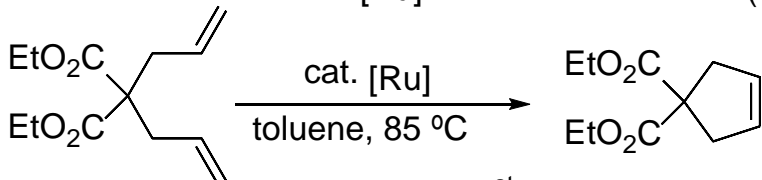

$[\mathrm{Ru}] 1^{\text {st }}$ Generation + $\mathrm{PhCCH}$ as cocatalyst $[R u] 2^{\text {nd }}$ Generation (no cocatalyst)<smiles>CCc1ccc(C)cc1C(Cl)(Cl)[R](Cl)(Cl)C=Cc1ccccc1</smiles>

$1^{\text {st }}$ Generation<smiles></smiles>

$2^{\text {nd }}$ Generation

Scheme 49

\section{Ruthenium Allenylidenes in Catalysis}

Allenylidenes ligands are divalent radicals derived from allenes and their metal derivatives can be easily obtained from terminal propargylic alcohols by dehydration of initially formed M-hydroxyvinylidenes.[90] Since the first report of the use of transition metal allenylidene complexes in catalytic reactions by Trost,[91] significant progress in this field has been made.[12e,j,k,92] The reactivities of metal allenylidene complexes are rationalized by considering the electrophilicity of $C \alpha$ and $C \gamma$ and the nucleophilicity of $C \beta$ of the $M=C=C=C_{2}$ moiety. 


\subsection{Nucleophilic Addition to Allenylidenes $C \gamma$}

The ability shown by transition metal allenylidenes to undergo nucleophilic additions at the $\mathrm{C} \gamma$ atom of the cumulenic chain has been used to develop efficient catalytic processes for the direct substitution of the hydroxyl group in propargylic alcohols.[92a] These studies were initiated[93] and further developed by Nishibayashi, Uemura and Hidai using as catalyst precursors the thiolate-bridged diruthenium(III) complexes $\left[\mathrm{Cp} * \mathrm{RuCl}(\mu \text {-SR) }]_{2}\left(\mathrm{R}=\mathrm{Me}, \mathrm{Et}, n-\mathrm{Pr}, i\right.\right.$-Pr) and $\left[\mathrm{Cp}^{*}\right.$ $\mathrm{RuCl}(\mu \text {-SR })_{2}$-RuCp* $\left.(\mathrm{OH})_{2}\right] \mathrm{OTf}$. The proposed mechanism requires the generation of allenylidene II by dehydration of the initially formed vinylidene I by treatment of the corresponding propargylic alcohol with the diruthenium complex in the presence of $\mathrm{NH}_{4} \mathrm{BF}_{4}$. Nucleophilic attack at the $\mathrm{C} \gamma$ of the allenylidene II would afford vinylidene species III, which after tautomerization to the $\eta^{2}$-coordinated alkyne-ruthenium IV would afford the propargylic-substituted product with recovery of the catalytic species (Scheme 50). 


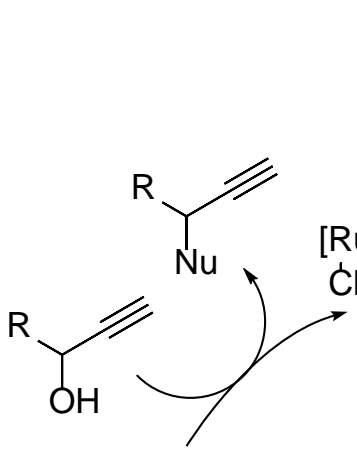

[Ru]- $[\mathrm{Ru}]$
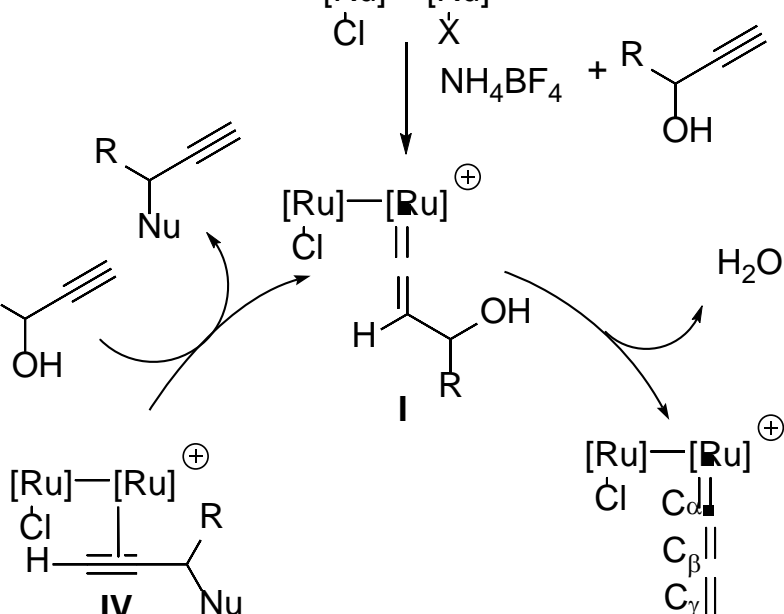

$[\mathrm{Ru}]-[\mathrm{Ru}]$

Cl Cd.<smiles>[C]1CC[As]1</smiles>

IV $\mathrm{Nu}$<smiles>[R]C([CH])=[CH]</smiles>

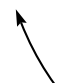<smiles>C1=CCCC1</smiles>

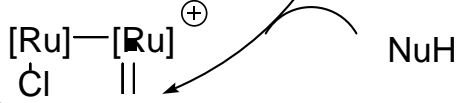

Ru $]-[\mathrm{Ru}$

Cl $\dot{x}$

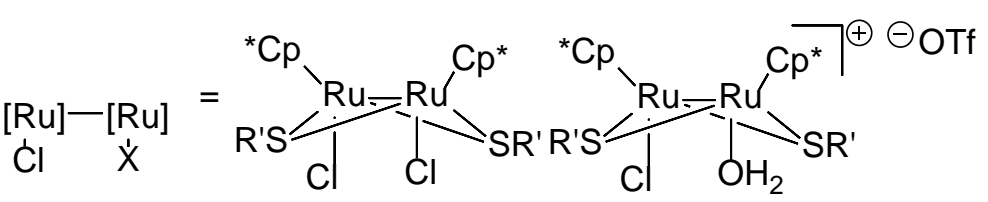<smiles>[R]C([AlH2])C([1H])=C</smiles>

$\mathrm{R}^{\prime}=\mathrm{Me}, \mathrm{Et}, i-\mathrm{Pr}, n-\mathrm{Pr}$

\section{Scheme 50}

The nucleophilic substitution of the hydroxy group in propargylic alcohols with a variety of heteroatom-centered nucleophiles, such as alcohols, amines, amides and diphenylphosphine oxide, to give the corresponding propargylic-substituted products with complete selectivity has been conveniently exploited.[94] One interesting modification of this methodology arises from the reaction of 1cyclopropyl-2-propyn-1-ols with nitrogen- and oxygen-centered nucleophiles such as anilines and water to afford functionalized conjugated enynes (Scheme 51).[95] 

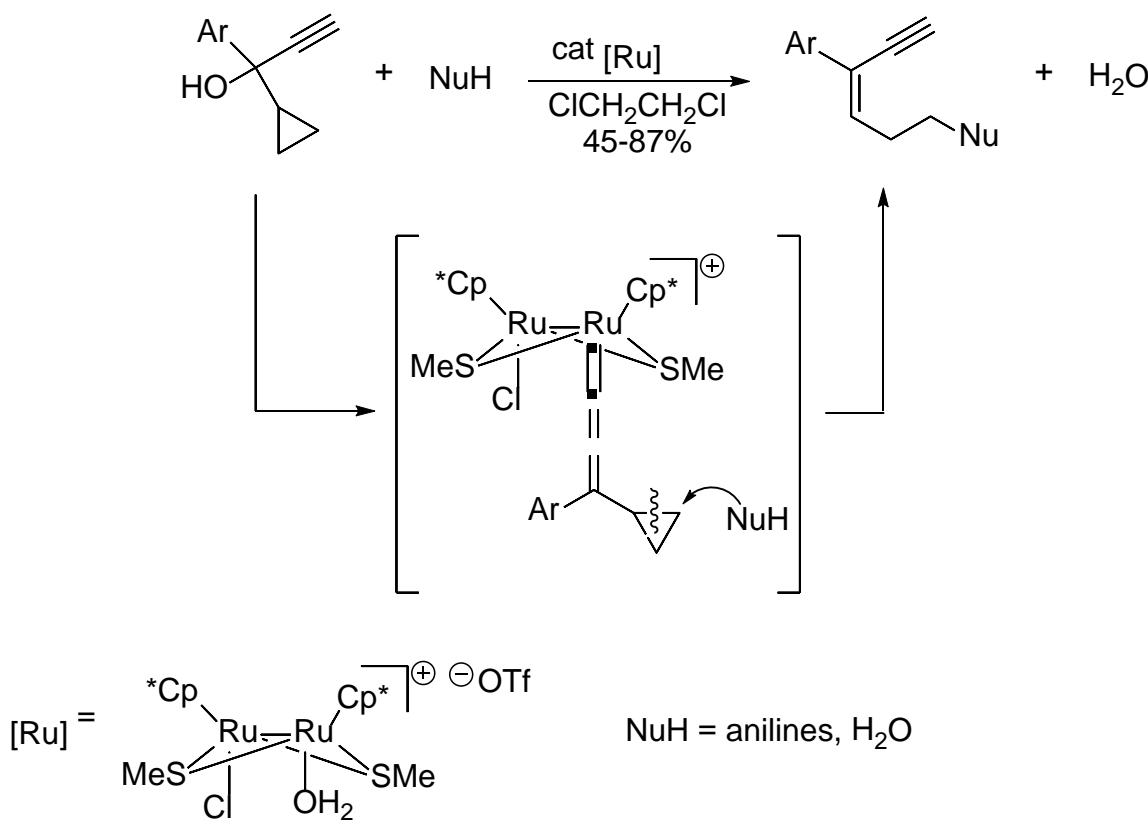

\section{Scheme 51}

Nishibayashi and Sakata recently described the Ru-catalyzed [3+2] cycloaddition of ethynylcyclopropanes bearing two carboxy groups at the homopropargylic position with aldehydes and aldimines to afford 2-ethynyltetrahydrofurans and pyrrolidines (Scheme 52).[96] The proposed mechanism requires the formation of the ruthenium allenylidene species II by isomerization of the initially formed vinylidene I. Nucleophilic attack of species II to the aldehyde or aldimine, which are activated by $\mathrm{BF}_{3} \cdot \mathrm{OEt}_{2}$, would afford allenylidene III. Final nucleophilic attack on the $\mathrm{C} \gamma$ by the oxygen or nitrogen followed by tautomerization of the vinylidene species IV would give rise to the corresponding 2-ethynyltetrahydrofurans and pyrrolidines, respectively. 


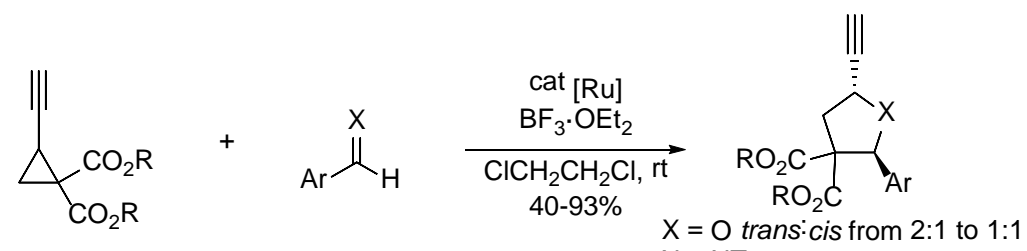

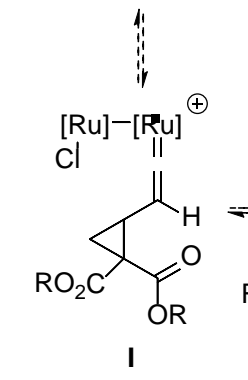

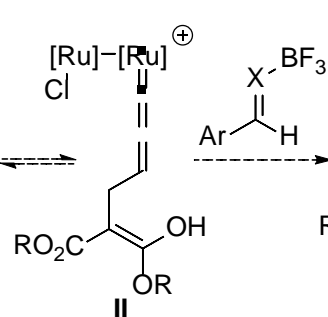
$X=$ NTs trans:cis from $1: 8$ to $1: 50$

$$
x=0, \text { NTs }
$$

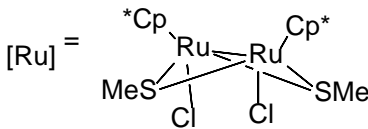

\section{Scheme 52}

The propargylic substitution with carbon-centered nucleophiles such as acetone has been reported to give $\gamma$-ketoalkynes,[97] heteroaromatic compounds such as furans, thiophenes, pyrroles and indoles and electron-rich arenes such as anilines, 1,3,5-trimethoxybenzene, 3,5-dimethoxylacetanilide and azulene.[98] The asymmetric version of the propargylic alcohol substitution with acetone[99] and hetero- and aromatic compounds[100] was achieved using a diruthenium complex incorporating a bridging chiral thiolate ligand (Scheme 53). The chiral induction of the process is believed to be determined by favorable $\pi-\pi$ interactions between one of the aromatic rings of the thiolate ligand and the aryl substituent of the alkynol in the corresponding allenylidene intermediate. 

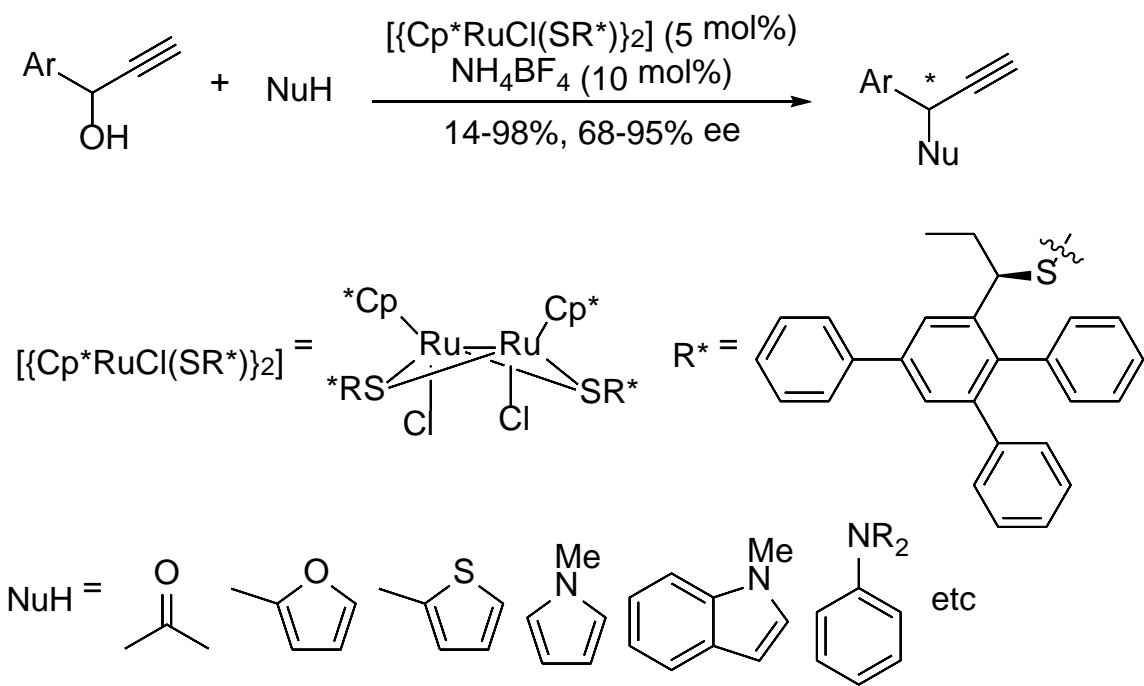

\section{Scheme 53}

The enantioselective propargylic alkylation of propargylic alcohols with aldehydes[101] or $\beta$-ketoesters[102] has recently been accomplished by cooperative catalytic reactions using a thiolate-bridged diruthenium complex and a chiral organocatalyst in the former case or a chiral copper complex in the latter. In both cases, the ruthenium complex activates the propargylic alcohols to afford the corresponding ruthenium allenylidene while aldehydes and $\beta$-ketoesters are activated by the chiral organocatalyst and the chiral copper complex, respectively (Scheme 54). 

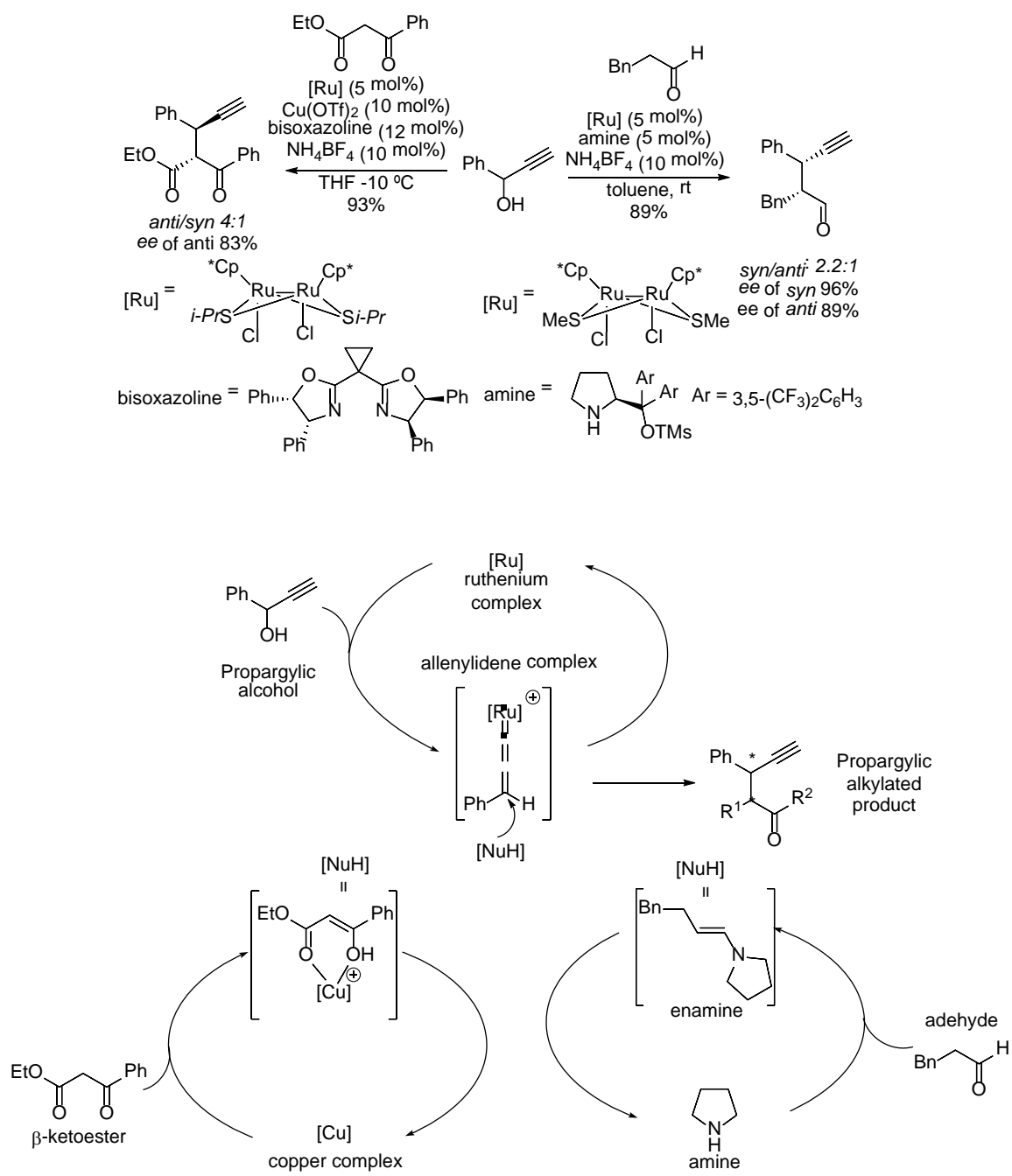

\section{Scheme 54}

\subsection{Nucleophilic Addition to Allenylidenes $C \alpha$}

The electrophilic $\mathrm{C} \alpha$ of allenylidenes is prone to add nucleophiles like ruthenium vinylidenes. The unsaturated $16 \mathrm{e}^{-}$complex $\left[\mathrm{Ru}\left(\eta^{3}-2-\mathrm{C}_{3} \mathrm{H}_{4} \mathrm{Me}\right)(\mathrm{CO})(\mathrm{dppf})\right]\left[\mathrm{SbF}_{6}\right]$ efficiently catalyzes the isomerization of both tertiary and secondary terminal propargylic alcohols into the corresponding enals or $\alpha, \beta$-unsaturated methyl ketones (Scheme 55).[103] The proposed mechanism involves the initial formation of the ruthenium vinylidene $\mathbf{I}$, which evolves to the corresponding 
allenylidene II if the propargylic alcohol does not bear a hydrogen in the $\beta$ position to the hydroxy group. Nucleophilic addition of water to the allenylidene $\mathrm{C} \alpha$ followed by tautomerization would afford acyl-ruthenium species III, which after protonolysis would give rise to the corresponding enal. Conversely, if the propargylic alcohol bears a hydrogen in the $\beta$-position to the hydroxy group, vinylidene I would undergo an elimination to give the new conjugated vinylidene species IV. Tautomerization to the corresponding Ru-alkyne complex $\mathbf{V}$ followed by Markovnikov hydration would afford the corresponding $\alpha, \beta$-unsaturated methyl ketone.

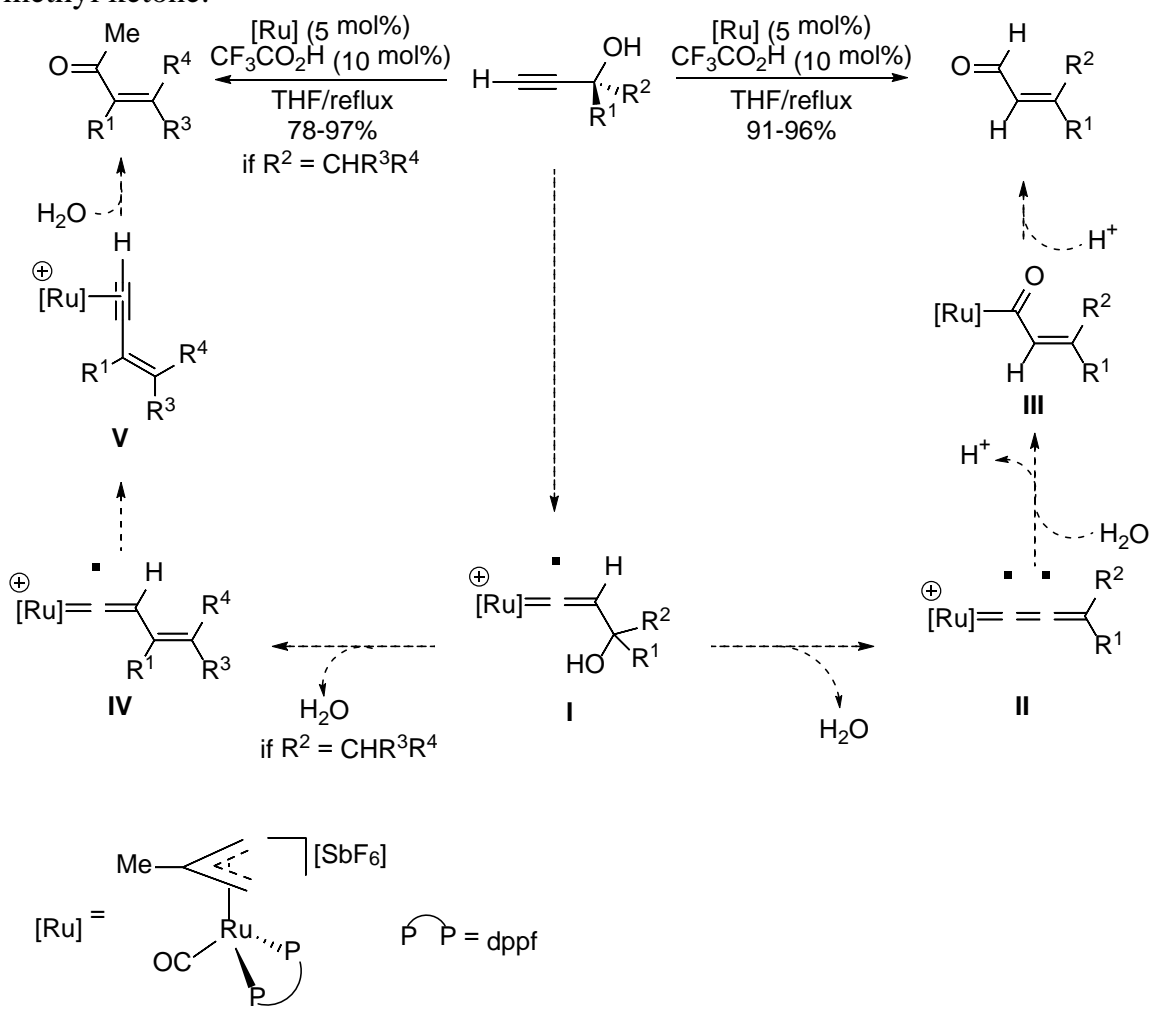

Scheme 55

If the same reaction is performed in the presence of an enolizable ketone, the initially formed enal can undergo an aldol-type condensation to afford the corresponding dienone, which can formally be regarded as a nucleophilic addition of a carbon-centered nucleophile to the C $\alpha$ of an allenylidene (Scheme 56).[104] 


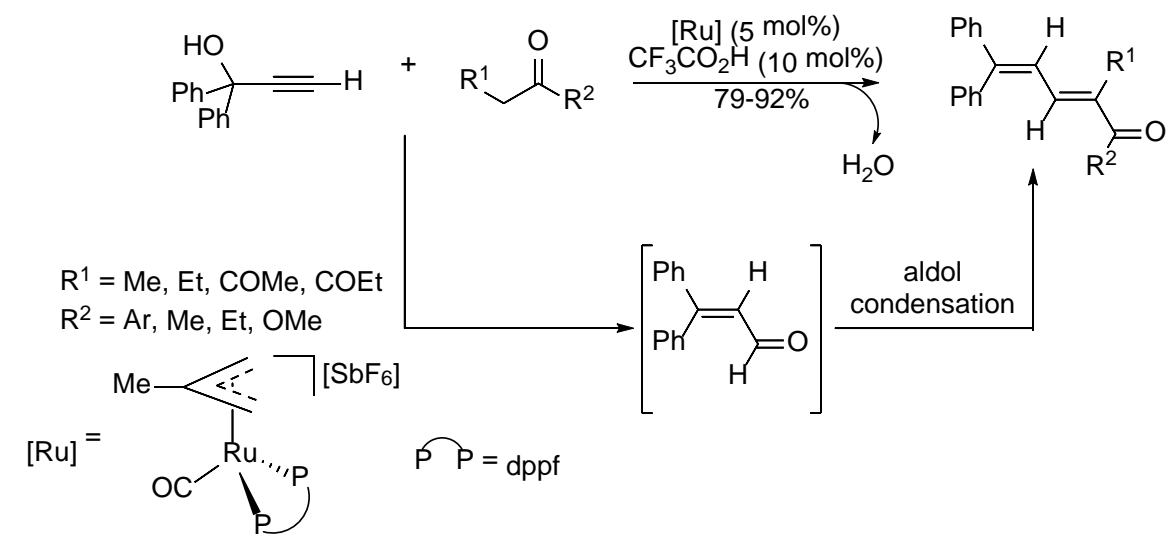

Scheme 56

\subsection{Pericyclic Reactions with Ruthenium Allenylidenes}

The $\pi$ system of ruthenium allenylidenes can also participate in pericyclic reactions such as cycloadditions and ene reactions to afford functionalized polycyclic products.

\subsubsection{Cycloadditions}

Thiolate-bridged diruthenium complexes catalyze the [3+3] cycloaddition reaction between propargylic alcohols and cyclic 1,3-dicarbonyl compounds to afford $4,6,7,8$-tetrahydrochromen-5-ones or $4 H$-cyclopenta[b]pyran-5-ones[105] and with 2-naphthols or phenols to afford $1 H$-naphtho[2,1-b]pyrans and $4 H-1$ benzopyrans, respectively.[106] This cycloaddition is considered to proceed by stepwise propargylation and intramolecular cyclization (carbon and oxygen nucleophile additions) reactions, where ruthenium allenylidene and vinylidene complexes are the key intermediates (Scheme 57). Enantioselective rutheniumcatalyzed [3+3] cycloaddition of propargylic alcohols with 2-naphthols has also been described.[107] 


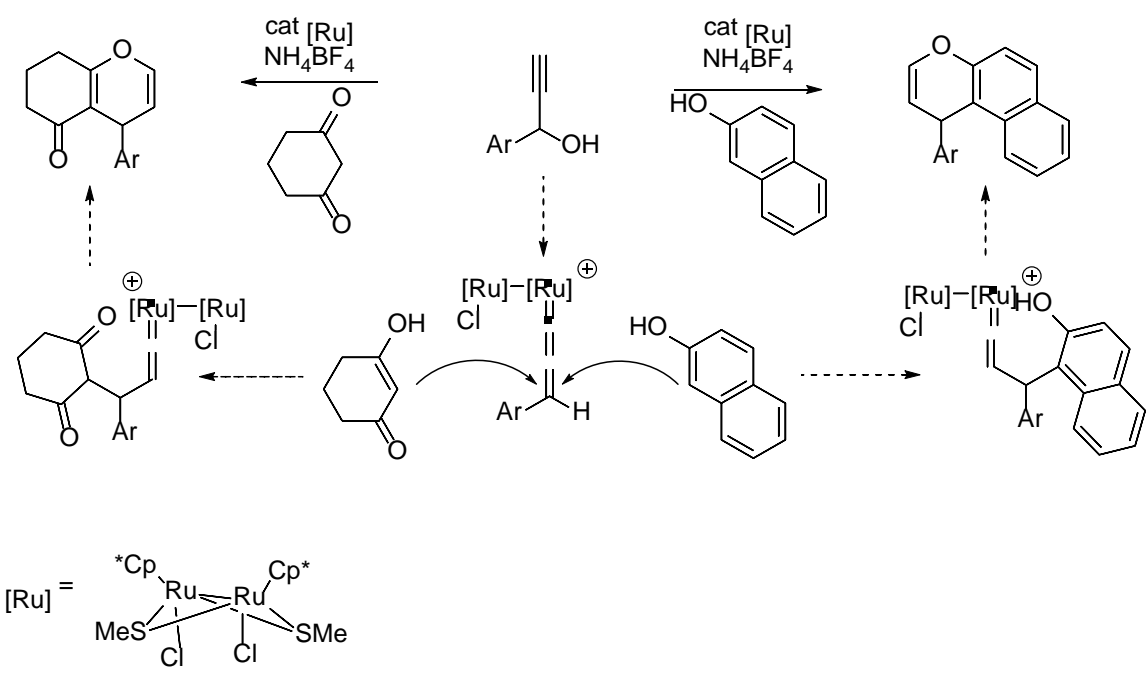

Scheme 57

\subsubsection{Allenylidene-ene Reactions}

Inter- and intramolecular additions of alkenes and dienes to propargylic alcohols catalyzed by thiolate-bridged diruthenium complexes have been described. The processes, a kind of allenylidene-ene reaction, generate 1,5-enynes and dienynes by reaction of propargylic alcohols with 2-arylpropenes[108] and 1,3-conjugated dienes,[109] respectively. The intramolecular version of this reaction has been developed to give diastereo-[108,110] or enantioselective syn-substituted chromanes (Scheme 58).[111] Recently, the results of DFT calculations indicated that nucleophilic attack of the olefinic $\pi$-electrons on a carbocationic rutheniumalkynyl $[\mathrm{Ru}]-\mathrm{C} \equiv \mathrm{C}-\mathrm{C}^{+} \mathrm{HR}$ complex, a resonance structure of the allenylidene intermediate $[\mathrm{Ru}]^{+}=\mathrm{C}=\mathrm{C}=\mathrm{CHR}$, is clearly involved in the catalytic cycle.[112] 


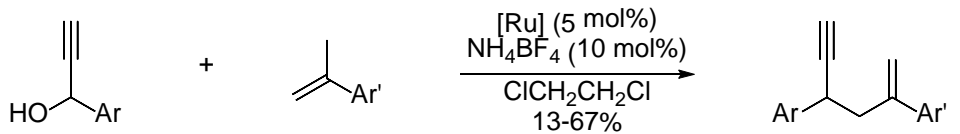

$[\mathrm{Ru}]={ }_{\mathrm{MeS}}^{{ }^{*} \mathrm{Cp}} \frac{\mathrm{Cl}}{\mathrm{Cl}}_{\mathrm{Cl}}^{\mathrm{Ru}_{\mathrm{CMe}}}{ }^{\mathrm{Cp}^{*}}$
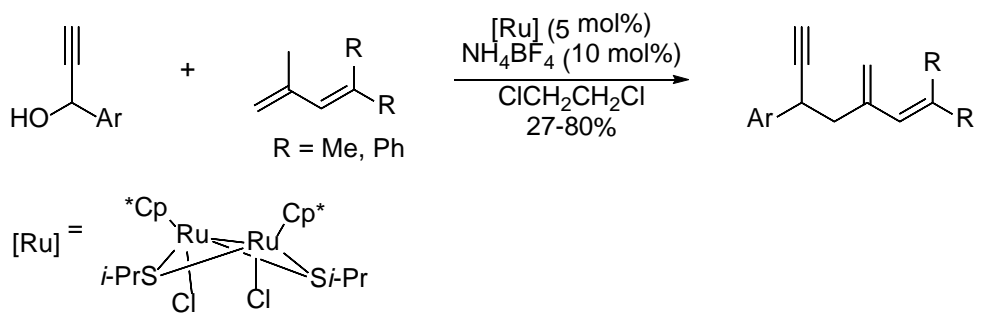

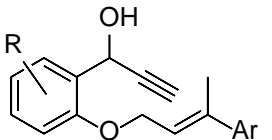

$\mathrm{R}=\mathrm{H}, 4-\mathrm{Me}, 6-\mathrm{Me}, 4-\mathrm{Cl}$

$\mathrm{Ar}=\mathrm{Ph}, p-\mathrm{MeC}_{6} \mathrm{H}_{4}$

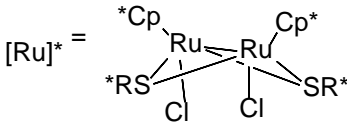

$$
\begin{gathered}
\underset{[\mathrm{Ru}]^{*}(10 \mathrm{~mol} \%)}{\mathrm{NH}_{4} \mathrm{BF}_{4}(20 \mathrm{~mol} \%)} \\
\underset{78-93 \%}{\mathrm{ClCH}_{2} \mathrm{CH}_{2} \mathrm{Cl}}
\end{gathered}
$$

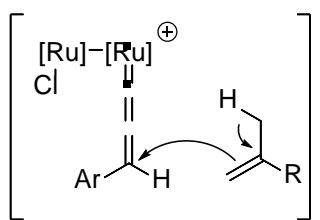

Allenylidene-ene reaction

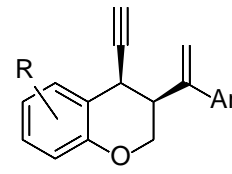

syn/anti: $2.3 / 1-17 / 1$

ee of syn: 90-93

\section{Scheme 58}

Lin and co-workers described the formation of 5,9-methanobenzoannulenes by $\left[\left(\mathrm{CpRu}\left(\mathrm{PPh}_{3}\right)_{2}\left(\mathrm{CH}_{3} \mathrm{CN}\right)\right]^{+}\right.$-catalyzed allenylidene-ene reactions of ortho-propenyl and ortho-butenylphenyl propargyl alcohols. The processes probably involve the initial formation of aromatic vinylidenes as intermediates and these undergo nucleophilic attack by the pendant olefinic double bonds and final trapping with $\mathrm{MeOH}$ (Scheme 59).[68] Similar cyclizations of enynes containing thioether or ether linkages have recently been described.[113] 


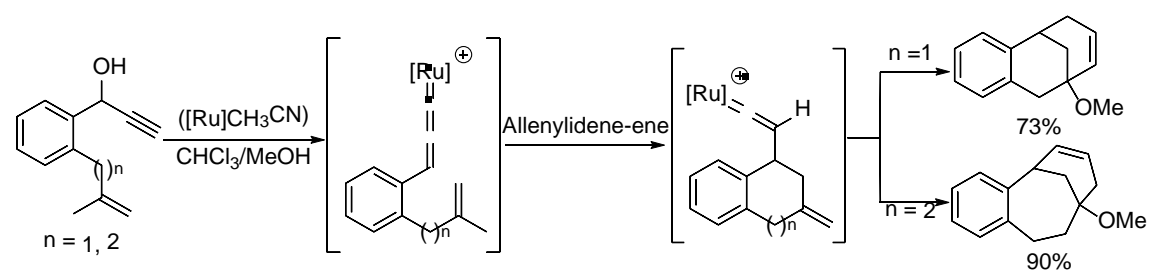

$[\mathrm{Ru}]=\mathrm{CpRu}\left(\mathrm{PPh}_{3}\right)_{2}$

Scheme 59

\subsection{Allenylideneruthenium Catalysts in Metathesis}

Allenylideneruthenium complexes, which are readily available and easy to handle, have become an alternative to the alkylideneruthenium complexes (the Grubbs catalyst family) in alkene metathesis.[12b,e,j,k,92b] The first catalytic applications of allenylidene complexes in alkene metathesis were described by Dixneuf's and Fürstner's groups, who used several well-defined 18-electron cationic ruthenium allenylidene complexes $\left[\mathrm{RuCl}(=\mathrm{C}=\mathrm{C}=\mathrm{CAr} 2)\left(\eta^{6}-p\right.\right.$-cymene $\left.\left.) \mathrm{PR}_{3}\right)\right][\mathrm{X}]$ (A, Figure 1).[114] Since then, electronic modifications on these cationic complexes have been studied thoroughly.[115] The following general trends were observed: (i) the activity increases with the electron richness and size of the phosphine ligand in the order $\mathrm{PCy}_{3}>\mathrm{Pi}-\mathrm{Pr}_{3}>>\mathrm{PPh}_{3}$; (ii) the nature of the counteranion of these ionic precursors has a dramatic influence on the catalytic activity, which increases in the order $\mathrm{TfO}^{-}>>\mathrm{PF}_{6}{ }^{-} \approx \mathrm{BF}_{4}^{-}$; (iii) several 3,3-diarylallenylidene ligands proved to be efficient, but the most simple 3,3-diphenylallenylideneruthenium derivatives led to the best performances. Modifications in the initial 18-electron cationic allenylidene complexes by using a chelate $\eta^{6}$-arene, $\eta^{1}$-carbene allenylidene ruthenium complex generated in situ (B, Figure 1) showed high activity and selectivity in some RCM reactions, with a strong influence of the diene and the solvent.[116]

Nolan and co-workers reported RCM reactions of neutral allenylideneruthenium complexes with a 16-electron metal center configuration, $\left.(\mathrm{PCy})_{2}\right)_{2}{ }_{2} \mathrm{Ru}\left(=\mathrm{C}=\mathrm{C}=\mathrm{CPh}_{2}\right)(\mathbf{C}$, Figure 1$)$, and its second generation analogs bearing an N-heterocyclic carbene ligand, $\left(\mathrm{PCy}_{3}\right)(\mathrm{IMes}) \mathrm{Cl}_{2} \mathrm{Ru}\left(=\mathrm{C}=\mathrm{C}=\mathrm{CPh}_{2}\right)(\mathbf{D}$, Figure 1).[117] Other ligand modifications and their influence in RCM reaction were investigated more recently.[118]

Cationic allenylideneruthenium complexes with a 16-electron metal center $\left[\mathrm{RuCl}\left(=\mathrm{C}=\mathrm{C}=\mathrm{CPh}_{2}\right)\left(\mathrm{PCy}_{3}\right)(\mathrm{DMSO})_{2}\right][\mathrm{OTf}]$ and with 18-electron neutral $\left[\mathrm{RuCl}_{2}\left(=\mathrm{C}=\mathrm{C}=\mathrm{CPh}_{2}\right)(\mathrm{PCy})_{2}(\mathrm{DMSO})\right]$ and $\left[\mathrm{RuCl}_{2}\left(=\mathrm{C}=\mathrm{C}=\mathrm{CPh}_{2}\right)\left(\mathrm{PCy}_{3}\right)(\mathrm{DMSO})_{2}\right]$ and cationic $\left[\mathrm{RuCl}\left(=\mathrm{C}=\mathrm{C}=\mathrm{CPh}_{2}\right)\left(\mathrm{PCy}_{3}\right)_{2}(\mathrm{DMSO})_{2}\right][\mathrm{OTf}]$ systems were tested in ROMP of cyclic olefins, but their efficiencies were found to be lower than those obtained with catalysts of type $\mathbf{A}$ in Figure 1.[119] 
Homobimetallic ruthenium allenylidene complex [(p-cymene $) \operatorname{Ru}(\mu$ $\left.\mathrm{Cl})_{3} \mathrm{RuCl}\left(\mathrm{PCy}_{3}\right)\left(\eta^{2}-\mathrm{C}_{2} \mathrm{H}_{4}\right)\right]$ (E, Figure 1) was synthesized and tested in RCM reactions.[120] However, later investigations revealed that the final catalysts formed were actually phenylindenylideneruthenium complexes rather than allenylidene analogs.[121] This latter homobimetallic ruthenium allenylidene complex was finally synthesized along with other ruthenium homobimetallic complexes and they were tested as catalysts in olefin metathesis.[122] Heterobimetallic allenylidene titanium-ruthenium complexes (F, Figure 1) have also shown catalytic activity in RCM reactions.[123]

Biocompatible water-soluble ruthenium allenylidenes (G, Figure 1)[124] and complexes of type A in ionic liquids have also been described.[115a,125] 

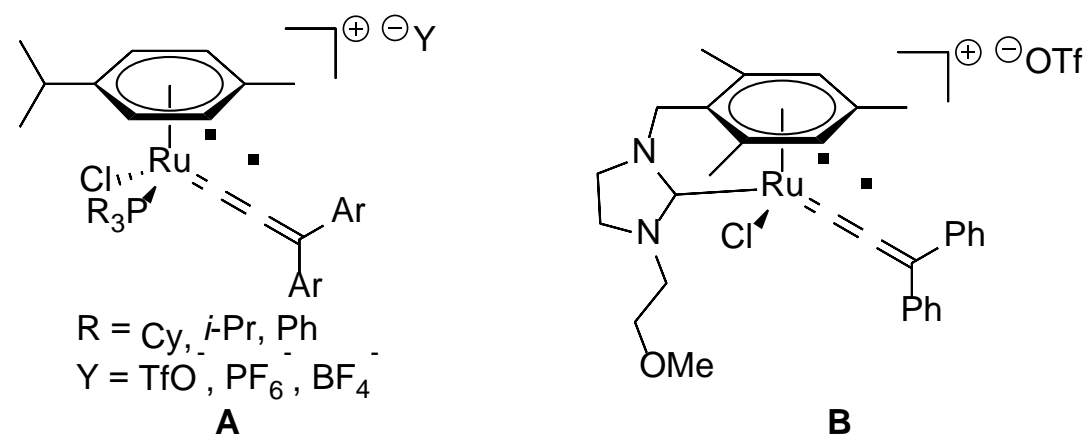

$\underset{\mathrm{Cl}}{\mathrm{Cl}} \underset{\mathrm{PCy}_{3}}{\stackrel{\mathrm{PCy}_{3}}{\mathrm{Ru}}=}=\left.\right|_{\mathrm{Ph}} ^{\mathrm{Ph}}$

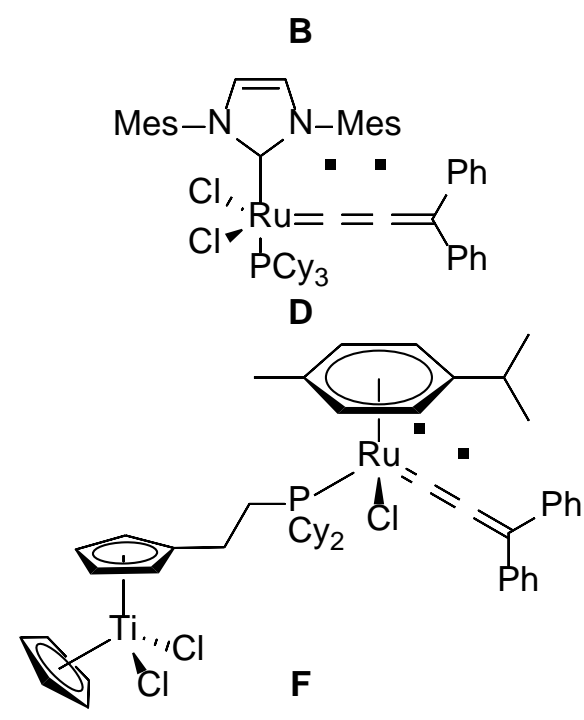

C

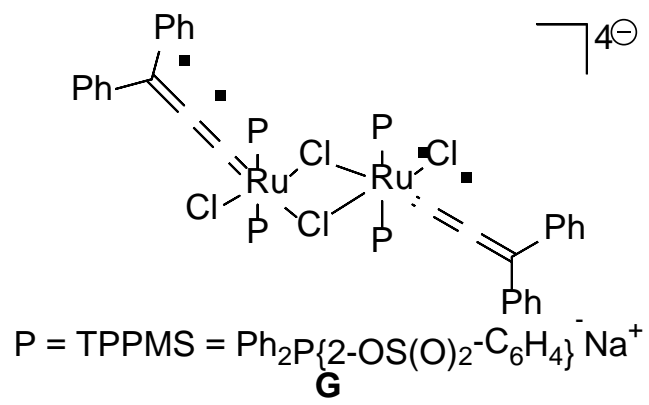

Figure 1 


\section{Conclusion}

The formation of catalytic ruthenium vinylidenes and allenylidenes has been revealed as one of the most powerful methods for the activation of compounds bearing terminal alkynes and propargylic alcohols, respectively. The chemical properties of the catalytic ruthenium vinylidenes and allenylidenes generated in situ change the reactivity of free alkynes, thus allowing new and selective reactions to be carried out with atom economy and significantly increased complexity. This reactivity hinges on the electrophilic character of the $\mathrm{C} \alpha$ in vinylidenes as well as $\mathrm{C} \alpha$ and $\mathrm{C} \gamma$ of allenylidenes and the capacity of the electronic $\pi$-system of both metallic intermediates to participate in pericyclic reactions.

\section{References}

[1] (a) Bruce MI, Swincer AG (1983) Adv Organomet Chem 22:59; (b) Antonova AB, Ioganson AA (1989) Russ Chem Rev 58:1197; (c) Davies SG, McNally JP, Smallridge AJ (1990) Adv Organomet Chem 30:1; (d) Bruce MI (1991) Chem Rev 91:197; (e) Bruce MI (1998) Chem Rev 98:2797

[2] (a) Mills OS, Redhouse AD (1968) J. Chem. Soc., A 1282; (b) Mills OS, Redhouse AD (1966) Chem Commun 444

[3] (a) Puerta MC, Valerga P (1999) Coord Chem Rev 193-195:977; (b) Cadierno V, Gamasa MP, Gimeno J (2004) Coord Chem Rev 248:1627; (c) Wakatsuki Y (2004) J Organomet Chem 689:4092; (d) Lynam JM (2010) Chem Eur J 16:8238; (e) Swennenhuis BHG, Cieslinski GB, Brothers EN, Bengali AA (2010) J Organomet Chem 695:891; (f) Wang Q, Wang X, Andrews L (2011) J Phys Chem A 115:12194

[4] (a) Wakatsuki Y, Koga N, Yamazaki H, Morokuma K (1994) J Am Chem Soc 116:8105; (b) Tokunaga M, Suzuki T, Koga N, Fukushima T, Horiuchi A, Wakatsuki Y (2001) J Am Chem Soc 123:11917; (c) De Angelis F, Sgamellotti A, Re N (2002) Organometallics 21:5944; (d) De Angelis F, Sgamellotti A, Re N (2002) Organometallics 21:2715

[5] (a) Wakatsuki Y, Koga N, Werner H, Morokuma K (1997) J Am Chem Soc 119:360; (b) Pérez-Carreño E, Paoli P, Ienco A, Mealli C (1999) Eur J Inorg Chem 1315; (c) Vastine BA, Hall MB (2008) Organometallics 27:4325; (d) Grotjahn DB, Zeng X, Cooksy AL (2006) J Am Chem Soc 128:2798; (e) Grotjahn DB, Zeng X, Cooksy AL, Kassel WS, DiPasquale AG, Zakharov LN, Rheingold AL (2007) Organometallics 26:3385; (f) De Angelis F, Sgamellotti A, Re N (2007) Organometallics 26:5285

[6] (a) Oliván M, Clot E, Eisenstein O, Caulton KG (1998) Organometallics 17:3091

[7] (a) Schneider D, Werner H (1991) Angew Chem Int Ed Engl 30:700; (b) Sakurai H, Fujii T, Sakamoto K (1992) Chem Lett 339; (c) Werner H, Baum M, Schneider D, Windmüller B (1994) Organometallics 13:1089; (d) Connelly NG, Geiger WE, Lagunas C, Metz B, Rieger AL, Rieger PH, Shaw MJ (1995) J Am Chem Soc 117:12202; (e) 
Naka A, Okazaki S, Hayashi M, Ishikawa M (1995) J Organomet Chem 499:35; (f) Onitsuka K, Katayama H, Sonogashira K, Ozawa F (1995) J Chem Soc Chem Commun 2267; (g) Katayama H, Onitsuka K, Ozawa F (1996) Organometallics 15:4642; (h) Werner H, Lass RW, Gevert O, Wolf J (1997) Organometallics 16:4077; (i) Katayama H, Ozawa F (1998) Organometallics 17:5190; (j) Huang D, Streib WE, Eisenstein O, Caulton KG (2000) Organometallics 19:1967; (k) Foerstner J, Kakoschke A, Goddard R, Rust J, Wartchow R, Butenschön H (2001) J Organomet Chem 617-618:412; (l) Murakami M, Hori S (2003) J Am Chem Soc 125:4720; (m) Jiménez MV, Sola E, Lahoz FJ, Oro LA (2005) Organometallics 24:2722; (n) Ilg K, Paneque M, Poveda ML, Rendón N, Santos LL, Carmona E, Mereiter K (2006) Organometallics 25:2230; (o) Konkol M, Steinborn D (2006) J Organomet Chem 691:2839; (p) Lass RW, Werner H (2011) Inorg. Chim. Acta 369:288

[8] (a) Venkatesan K, Blacque O, Fox T, Alfonso M, Schmalle HW, Kheradmandan S, Berke H (2005) Organometallics 24:920; (b) Venkatesan K, Fox T, Schmalle HW, Berke H (2005) Eur J Inorg Chem 2005:901

[9] (a) Miller DC, Angelici RJ (1991) Organometallics 10:79

[10] (a) Löwe C, Hund H-U, Berke H (1989) J Organomet Chem 371:311; (b) I: Miura T, Iwasawa N (2002) J Am Chem Soc 124:518; (c) Miura T, Murata H, Kiyota K, Kusama H, Iwasawa N (2004) J Mol Catal A 213:59

[11] (a) Shaw MJ, Bryant SW, Rath N (2007) Eur J Inorg Chem 3943; (b) Ikeda Y, Yamaguchi T, Kanao K, Kimura K, Kamimura S, Mutoh Y, Tanabe Y, Ishii Y (2008) J Am Chem Soc 130:16856; (c) Mutoh Y, Ikeda Y, Kimura Y, Ishii Y (2009) Chem Lett 38:534; (d) de los Ríos I, Bustelo E, Puerta MC, Valerga P (2010) Organometallics 29:1740; (e) Mutoh Y, Imai K, Kimura Y, Ikeda Y, Ishii Y (2011) Organometallics 30:204; (f) Singh VK, Bustelo E, de los Ríos I, Macías-Arce I, Puerta MC, Valerga P, Ortuño MA, Ujaque G, Lledós A (2011) Organometallics 30:4014; (g) Mutoh Y, Kimura Y, Ikeda Y, Tsuchida N, Takano K, Ishii Y (2012) Organometallics 31:5150 (h) Otsuka M, Tsuchida N, Ikeda Y, Kimura Y, Mutoh Y, Ishii Y, Takano K (2012) J Am Chem Soc 134:17746

[12] (a) Fishmeister C, Bruneau C, Dixneuf, PH (2004) Nucleophilic Additions to Alkynes and Reactions via Vinylidene Intermediates. In: Murahashi SI (ed) Ruthenium in Organic Synthesis, Wiley-VCH, Weinheim, chap 8; (b)Bruneau C (2004) Top. Organomet. Chem. 11:125; (c) Katayama H, Ozawa F (2004) Coord Chem Rev 248:1703; (d) Dragutan V, Dragutan I (2004) Platinum Met Rev 48:148; (e) Bruneau C, Dixneuf PH (2006) Angew Chem Int Ed 45:2176; (f) Varela JA, Saá C (2006) Chem Eur J 12:6450; (g) Varela JA, González-Rodríguez C, Rubín SG, Castedo L, Saá C (2008) Pure Appl Chem 80:1167; (h) Trost BM, McClory A (2008) Chem Asian J 3:164; (i) Liu R-S (2008) Synlett 801;(j) Bruneau C, Dixneuf PH (2008) Metal Vinylidenes and Allenylidenes in Catalysis: From Reactivity to Applications in Synthesis. Wiley-VCH, Winheim, Germany; (k) Lozano-Vila AM, Monsaert S, Bajek A, Verpoort F (2010) Chem Rev 110:4865

[13] Sasaki Y, Dixneuf PH (1986) J Chem Soc Chem Commun 790

[14] (a) Mahe R, Dixneuf PH, Lecolier S (1986) Tetrahedron Lett 27:6333; (b) Sasaki Y, Dixneuf PH (1987) J Org Chem 52:314; (c) Bruneau C, Dixneuf PH, Lecolier S (1988) J. Mol. Catal. 44:175; (d) Mahe R, Sasaki Y, Bruneau C, Dixneuf PH (1989) J Org Chem 54:1518; (e) Höfer J, Doucet H, Bruneau C, Dixneuf PH (1991) Tetrahedron Lett 32:7409; (f) Bruneau C, Dixneuf PH (1992) J. Mol. Catal. 74:97

[15] Ruppin C, Dixneuf PH (1986) Tetrahedron Lett 27:6323

[16] (a) Doucet H, Höfer J, Bruneau C, Dixneuf PH (1993) J Chem Soc Chem Commun 850; (b) Doucet H, Martin-Vaca B, Bruneau C, Dixneuf PH (1995) J Org Chem 
60:7247; (c) Doucet H, Höfer J, Derrien N, Bruneau C, Dixneuf PH (1996) Bull. Soc. Chim. Fr. 133:939

[17] Goossen LJ, Paetzold J, Koley D (2003) Chem Commun 706

[18] Jiménez-Tenorio M, Puerta MC, Valerga P, Moreno-Dorado FJ, Guerra FM, Massanet GM (2001) Chem Commun 2324

[19] Melis K, Samulkiewicz P, Rynkowski J, Verpoort F (2002) Tetrahedron Lett 43:2713

[20] (a) Picquet M, Bruneau C, Dixneuf PH (1997) Chem. Commun 1201; (b) Picquet M, Fernández A, Bruneau C, Dixneuf PH (2000) Eur J Org Chem 2361

[21] Tokunaga M, Wakatsuki Y (1998) Angew Chem Int Ed 37:2867

[22] Suzuki T, Tokunaga M, Wakatsuki Y (2001) Org Lett 3:735

[23] Grotjahn DB, Incarvito CD, Rheingold AL (2001) Angew Chem Int Ed 40:3884

[24] Chevallier F, Breit B (2006) Angew Chem Int Ed 45:1599

[25] Grotjahn DB, Lev DA (2004) J Am Chem Soc 126:12232

[26]Labonne A, Kribber T, Hintermann L (2006) Org Lett 8:5853

[27] Hintermann L, Dang TT, Labonne A, Kribber T, Xiao L, Naumov P (2009) Chem Eur J 15:7167

[28] Boeck F, Kribber T, Xiao L, Hintermann L (2011) J Am Chem Soc 133:8138

[29] (a) Labonne A, Zani L, Hintermann L, Bolm C (2007) J Org Chem 72:5704; (b) Kribber T, Labonne A, Hintermann L (2007) Synthesis 2007:2809

[30] (a) Trost BM, Dyker G, Kulawiec RJ (1990) J Am Chem Soc 112:7809; (b) Trost BM, Kulawiec RJ (1992) J Am Chem Soc 114:5579; (c) Trost BM, Flygare JA (1992) J Am Chem Soc 114:5476; (d) Trost BM, Kulawiec RJ, Hammes A (1993) Tetrahedron Lett 34:587; (e) Trost BM, Flygare JA (1994) J Org Chem 59:1078

[31] (a) McDonald FE (1999) Chem Eur J 5:3103; (b) McDonald FE, Reddy KS (2001) J Organomet Chem 617-618:444

[32] Trost BM, Rhee YH (1999) J Am Chem Soc 121:11680

[33] Trost BM, Rhee YH (2002) J Am Chem Soc 124:2528

[34] Zacuto MJ, Tomita D, Pirzada Z, Xu F (2010) Org Lett 12:684

[35] (a) Liu PN, Su FH, Wen TB, Sung HHY, Williams ID, Jia G (2010) Chem Eur J 16:7889; (b) Liu PN, Wen TB, Ju KD, Sung HHY, Williams ID, Jia G (2011) Organometallics 30:2571

[36] Varela-Fernández A, González-Rodríguez C, Varela JA, Castedo L, Saá C (2009) Org Lett 11:5350

[37] Nair RN, Lee PJ, Rheingold AL, Grotjahn DB (2010) Chem Eur J 16:7992

[38] (a) Alcázar E, Pletcher JM, McDonald FE (2004) Org Lett 6:3877; (b) Koo B, McDonald FE (2007) Org Lett 9:1737

[39] Varela-Fernández A, García-Yebra C, Varela JA, Esteruelas MA, Saá C (2010) Angew Chem Int Ed 49:4278

[40] Lo C-Y, Guo H, Lian J-J, Shen F-M, Liu R-S (2002) J Org Chem 67:3930

[41] Madhushaw RJ, Lin M-Y, Sohel SMA, Liu R-S (2004) J Am Chem Soc 126:6895

[42] Lin M-Y, Maddirala SJ, Liu R-S (2005) Org Lett 7:1745

[43] Koelle U, Rietmann C, Tjoe J, Wagner T, Englert U (1995) Organometallics 14:703

[44] Fukumoto Y, Dohi T, Masaoka H, Chatani N, Murai S (2002) Organometallics 21:3845

[45] Goossen LJ, Rauhaus JE, Deng G (2005) Angew Chem Int Ed 44:4042

[46] Goossen LJ, Arndt M, Blanchot M, Rudolphi F, Menges F, Niedner-Schatteburg G (2008) Adv Synth Catal 350:2701

[47] Buba AE, Arndt M, Goossen LJ (2010) J Organomet Chem 696:170

[48] Goossen LJ, Salih KS, Blanchot M (2008) Angew Chem Int Ed 47:8492

[49] Goossen LJ, Blanchot M, Salih KSM, Karch R, Rivas-Nass A (2008) Org Lett 10:4497 
[50] Goossen LJ, Blanchot M, Brinkmann C, Goossen K, Karch R, Rivas-Nass A (2006) J Org Chem 71:9506

[51] Arndt M, Salih KSM, Fromm A, Goossen LJ, Menges F, Niedner-Schatteburg G (2011) J Am Chem Soc 133:7428

[52] (a) Varela-Fernández A, Varela JA, Saá C (2011) Adv Synth Catal 353:1933; (b) Varela-Fernández A, Varela JA, Saá C (2012) Synthesis 44:3285

[53] Jérôme F, Monnier F, Lawicka H, Dérien S, Dixneuf PH (2003) Chem Commun 696

[54] (a) Bianchini C, Peruzzini M, Zanobini F, Frediani P, Albinati A (1991) J Am Chem Soc 113:5453; (b) Bianchini C, Frediani P, Masi D, Peruzzini M, Zanobini F (1994) Organometallics 13:4616

[55] (a)Yamazaki H (1976) J Chem Soc Chem Commun 841; (b) Wakatsuki Y, Yamazaki H, Kumegawa N, Satoh T, Satoh JY (1991) J Am Chem Soc 113:9604; (c) Wakatsuki Y, Yamazaki H (1995) J Organomet Chem 500:349

[56] (a) Slugovc C, Mereiter K, Zobetz E, Schmid R, Kirchner K (1996) Organometallics 15:5275; (b) Slugovc C, Doberer D, Gemel C, Schmidt R, Kirchner K, Winkler B, Stelzer F (1998) Monatsh. Chem. 129:221; (c) Pavlik S, Gemel C, Slugovc C, Mereiter K, Schmid R, Kirchner K (2001) J Organomet Chem 617-618:301

[57] Jiménez-Tenorio MA, Jiménez-Tenorio M, Puerta MC, Valerga P (2000) Organometallics 19:1333

[58] Fryzuk MD, Jonker MJ, Rettig SJ (1997) Chem Commun 377

[59] Bassetti M, Marini S, Tortorella F, Cadierno V, Diez J, Gamasa MP, Gimeno J (2000) J Organomet Chem 593-594:292

[60] Melis K, De Vos D, Jacobs P, Verpoort F (2002) J Organomet Chem 659:159

[61] Lee J-H, Caulton KG (2008) J Organomet Chem 693:1664

[62] (a) Yi CS, Liu N (1996) Organometallics 15:3968; (b) Yi CS, Liu N (1999) Synlett 281

[63] Chen X, Xue P, Sung HHY, Williams ID, Peruzzini M, Bianchini C, Jia G (2005) Organometallics 24:4330

[64] Katayama H, Yari H, Tanaka M, Ozawa F (2005) Chem Commun 4336

[65] Katayama H, Nakayama M, Nakano T, Wada C, Akamatsu K, Ozawa F (2004) Macromolecules 37:13

[66] (a) Shen H-C, Pal S, Lian J-J, Liu R-S (2003) J Am Chem Soc 125:15762; (b) Madhushaw RJ, Lo C-Y, Hwang C-W, Su M-D, Shen H-C, Pal S, Shaikh IR, Liu R-S (2004) J Am Chem Soc 126:15560

[67] Fukamizu K, Miyake Y, Nishibayashi Y (2009) Angew Chem Int Ed 48:2534

[68] Ma H-W, Lin Y-C, Huang S-L (2012) Org Lett 14:3846

[69] Gunanathan C, Hölscher M, Pan F, Leitner W (2012) J Am Chem Soc 134:14349

[70] Chen Y, Ho DM, Lee C (2005) J Am Chem Soc 127:12184

[71] Varela JA, González-Rodríguez C, Rubín SG, Castedo L, Saá C (2006) J Am Chem Soc 128:9576

[72] González-Rodríguez C, Varela JA, Castedo L, Saá C (2007) J Am Chem Soc 129:12916

[73] Kim H, Goble SD, Lee C (2007) J Am Chem Soc 129:1030

[74] Merlic CA, Pauly ME (1996) J Am Chem Soc 118:11319

[75] Lian JJ, Odedra A, Wu CJ, Liu RS (2005) J Am Chem Soc 127:4186

[76] Pati K, Liu R-S (2009) Chem Commun 5233

[77] (a) Murakami M, Ubukata M, Ito Y (1998) Tetrahedron Lett 39:7361; (b) Murakami M, Ubukata M, Ito Y (2002) Chem Lett 294

[78] Murakami M, Hori S (2003) J Am Chem Soc 125:4720 
[79] Johnson DG, Lynam JM, Mistry NS, Slattery JM, Thatcher RJ, Whitwood AC (2013) J Am Chem Soc 135:2222

[80] Elakkari E, Floris B, Galloni P, Tagliatesta P (2005) Eur J Org Chem 889

[81] Datta S, Odedra A, Liu RS (2005) J Am Chem Soc 127:11606

[82] Odedra A, Datta S, Liu RS (2007) J Org Chem 72:3289

[83] Grubbs, RH (2003) Handbook of Metathesis. Wiley-VCH

[84] (a) del Río I, van Koten G (1999) Tetrahedron Lett 40:1401; (b) Katayama H, Urushima H, Ozawa F (2000) J Organomet Chem 606:16

[85] Schwab P, Grubbs RH, Ziller JW (1996) J Am Chem Soc 118:100

[86] (a) Katayama H, Ozawa F (1998) Chem Lett 67; (b) Katayama H, Ozawa F (1998) Organometallics 17:5190; (c) Katayama H, Yoshida T, Ozawa F (1998) J Organomet Chem 562:203; (d) Saoud M, Romerosa A, Peruzzini M (2000) Organometallics 19:4005; (e) Katayama H, Yonezawa F, Nagao M, Ozawa F (2002) Macromolecules 35:1133; (f) Maya VG, Contreras AP, Canseco M-A, Tlenkopatchev MA (2001) React. Funct. Polym. 49:145; (g) Contreras AP, Cerda AM, Tlenkopatchev MA (2002) Macromol. Chem. Phys. 203:1811

[87] (a) Louie J, Grubbs RH (2001) Angew Chem Int Ed 40:247; (b) Opstal T, Verpoort F (2003) J. Mol. Catal. A: Chem. 200:49

[88] Borguet Y, Sauvage X, Zaragoza G, Demonceau A, Delaude L (2010) Organometallics 29:6675

[89] Borguet Y, Sauvage X, Zaragoza G, Demonceau A, Delaude L (2011) Organometallics 30:2730

[90] Selegue JP (1982) Organometallics 1:217

[91] Trost BM, Flygare JA (1992) J Am Chem Soc 114:5476

[92] (a) Nishibayashi Y, Uemura S (2006) Curr. Org. Chem. 10:135; (b) Cadierno V, Gimeno J (2009) Chem Rev 109:3512;(c) Nishibayashi Y (2012) Synthesis 44:489

[93] Nishibayashi Y, Wakiji I, Hidai M (2000) J Am Chem Soc 122:11019

[94] Nishibayashi Y, Milton MD, Inada Y, Yoshikawa M, Wakiji I, Hidai M, Uemura S (2005) Chem Eur J 11:1433

[95] Yamauchi Y, Onodera G, Sakata K, Yuki M, Miyake Y, Uemura S, Nishibayashi Y (2007) J Am Chem Soc 129:5175

[96] Miyake Y, Endo S, Moriyama T, Sakata K, Nishibayashi Y (2013) Angew Chem Int Ed 52:1758

[97] (a) Nishibayashi Y, Wakiji I, Ishii Y, Uemura S, Hidai M (2001) J Am Chem Soc 123:3393; (b) Nishibayashi Y, Imajima H, Onodera G, Inada Y, Hidai M, Uemura S (2004) Organometallics 23:5100

[98] (a) Nishibayashi Y, Yoshikawa M, Inada Y, Hidai M, Uemura S (2002) J Am Chem Soc 124:11846; (b) Inada Y, Yoshikawa M, Milton MD, Nishibayashi Y, Uemura S (2006) Eur J Org Chem 881

[99] Inada Y, Nishibayashi Y, Uemura S (2005) Angew Chem Int Ed 44:7715

[100] (a) Matsuzawa H, Miyake Y, Nishibayashi Y (2007) Angew Chem Int Ed 46:6488;

(b) Matsuzawa H, Kanao K, Miyake Y, Nishibayashi Y (2007) Org Lett 9:5561; (c) Kanao K, Matsuzawa H, Miyake Y, Nishibayashi Y (2008) Synthesis 3869

[101] Ikeda M, Miyake Y, Nishibayashi Y (2010) Angew Chem Int Ed 49:7289

[102] Ikeda M, Miyake Y, Nishibayashi Y (2012) Chem Eur J 18:3321

[103] (a) Cadierno V, Díez J, García-Garrido SE, Gimeno J (2004) Chem Commun 2716; (b) Cadierno V, García-Garrido SE, Gimeno J (2006) Adv Synth Catal 348:101

[104] Cadierno V, Díez J, Garcia-Garrido SE, Gimeno J, Nebra N (2006) Adv Synth Catal 348:2125 
[105] Nishibayashi Y, Yoshikawa M, Inada Y, Hidai M, Uemura S (2004) J Org Chem 69:3408

[106] Nishibayashi Y, Inada Y, Hidai M, Uemura S (2002) J Am Chem Soc 124:7900

[107] Kanao K, Miyake Y, Nishibayashi Y (2010) Organometallics 29:2126

[108] Nishibayashi Y, Inada Y, Hidai M, Uemura S (2003) J Am Chem Soc 125:6060

[109] Daini M, Yoshikawa M, Inada Y, Uemura S, Sakata K, Kanao K, Miyake Y, Nishibayashi Y (2008) Organometallics 27:2046

[110] Nishibayashi Y, Yoshikawa M, Inada Y, Hidai M, Uemura S (2004) J Am Chem Soc 126:16066

[111] Fukamizu K, Miyake Y, Nishibayashi Y (2008) J Am Chem Soc 130:10498

[112] Sakata K, Miyake Y, Nishibayashi Y (2009) Chem Asian J 4:81

[113] Feng Y-J, Lo J-X, Lin Y-C, Huang S-L, Wang Y, Liu Y-H (2013) Organometallics 32:6379

[114] (a) Füstner A, Picquet M, Bruneau C, Dixneuf PH (1998) Chem Commun 1315; (b) Picquet M, Touchard D, Bruneau C, Dixneuf PH (1999) New J Chem 23:141; (c) Fürstner A, Liebl M, Lehmann CW, Picquet M, Kunz R, Bruneau C, Touchard D, Dixneuf PH (2000) Chem Eur J 6:1847

[115] (a) Sémeril D, Olivier-Bourbigou H, Bruneau C, Dixneuf PH (2002) Chem Commun 146; (b) Antonucci A, Bassetti M, Bruneau C, Dixneuf PH, Pasquini C (2010) Organometallics 29:4524

[116] Çetinkaya B, Demir S, Özdemir I, Toupet L, Sémeril D, Bruneau C, Dixneuf PH (2003) Chem Eur J 9:2323

[117] Schanz H-J, Jafarpour L, Stevens ED, Nolan SP (1999) Organometallics 18:5187

[118] (a) Ledoux N, Drozdzak R, Allaert B, Linden A, Van DVP, Verpoort F (2007) Dalton Trans. 5201; (b) Lichtenheldt M, Kress S, Blechert S (2012) Molecules 17:5177

[119] (a)Alaoui AI, Sémeril D, Dixneuf PH (2002) J. Mol. Catal. A: Chem. 182-183:577; (b) Özdemir I, Demir S, Çetinkaya B, Toupet L, Castarlenas R, Fischmeister C, Dixneuf PH (2007) Eur J Inorg Chem 2862

[120] Fürstner A, Liebl M, Hill AF, Wilton-Ely JDET (1999) Chem Commun 601

[121] (a) Jafarpour L, Schanz H-J, Stevens ED, Nolan SP (1999) Organometallics 18:5416; (b) Fürstner A, Guth O, Duffels A, Seidel G, Liebl M, Gabor B, Mynott R (2001) Chem Eur J 7:4811; (c) Sauvage X, Borguet Y, Zaragoza G, Demonceau A, Delaude L (2009) Adv Synth Catal 351:441;

[122] Sauvage X, Borguet Y, Demonceau A, Delaude L (2010) Macromol. Symp. 293:24

[123] Le Gendre P, Picquet M, Richard P, Moïse C (2002) J Organomet Chem 643-644:231

[124] Saoud M, Romerosa A, Peruzzini M (2000) Organometallics 19:4005

[125] Csihony S, Fischmeister C, Bruneau C, Horvath IT, Dixneuf PH (2002) New J Chem 26:1667 